TIELY ZURLO MOGNHOL

GESTÃO DE PROJETOS EM EMPREENDIMENTOS DE INFRAESTRUTURA: ESTUDO COMPARATIVO DE CONSTRUTORAS BRASILEIRAS E CONSTRUTORAS INTERNACIONAIS ATUANDO NO BRASIL

São Paulo 


\section{TIELY ZURLO MOGNHOL}

Gestão de projetos em empreendimentos de infraestrutura: estudo comparativo de construtoras brasileiras e construtoras internacionais atuando no Brasil

Dissertação apresentada à Escola Politécnica da Universidade de São Paulo para obtenção do Título de Mestre em Ciências

São Paulo 


\section{TIELY ZURLO MOGNHOL}

Gestão de projetos em empreendimentos de infraestrutura: estudo comparativo de construtoras brasileiras e construtoras internacionais atuando no Brasil

Dissertação apresentada à Escola Politécnica da Universidade de São

Paulo para obtenção do Título de Mestre em Ciências

Área de Concentração:

Engenharia de Construção Civil e Urbana

Orientador: Prof. Livre-Docente Silvio Burrattino Melhado

São Paulo 
Autorizo a reprodução e divulgação total ou parcial deste trabalho, por qualquer meio convencional ou eletrônico, para fins de estudo e pesquisa, desde que citada a fonte.

Este exemplar foi revisado e corrigido em relação à versão original, sob responsabilidade única do autor e com a anuência de seu orientador.

São Paulo, de de

Assinatura do autor:

Assinatura do orientador:

\section{Catalogação-na-publicação}

Mognhol, Tiely

Gestão de projetos em empreendimentos de infraestrutura: estudo comparativo de construtoras brasileiras e construtoras internacionais atuando no Brasil / T. Mognhol -- versão corr. -- São Paulo, 2019.

$135 \mathrm{p}$.

Dissertação (Mestrado) - Escola Politécnica da Universidade de São Paulo. Departamento de Engenharia de Construção Civil.

1.Gestão de projetos 2.Construção internacional 3.Sucesso I.Universidade de São Paulo. Escola Politécnica. Departamento de Engenharia de Construção Civil II.t. 
Aos meus pais, Marcos e Simone, por serem exemplo de dedicação e amor.

Ao meu irmão querido, Tiago, in memorian, por ser companheiro e me proporcionar tantas alegrias.

À minha família, pelo apoio incondicional e compreensão nos momentos em que estive ausente. 


\section{AGRADECIMENTOS}

A Deus, por permitir-me trilhar os melhores caminhos e conduzir-me a pessoas maravilhosas, que muito contribuíram com este trabalho.

Ao professor e orientador, Silvio Melhado, por acreditar em meu potencial e apostar no tema deste trabalho. Sou imensamente grata pela orientação, dedicação, paciência, ensinamentos e por contribuir com o meu crescimento acadêmico, profissional e pessoal.

Aos colegas de curso, em especial à Tassia Farssura e Karina Matias, pela amizade e ensinamentos.

Aos professores da Escola Politécnica da Universidade de São Paulo (USP), pelos conhecimentos transmitidos e pelo incentivo à produção acadêmica.

À Profa. Dra. Marly Monteiro de Carvalho, pelos conhecimentos transmitidos em sala de aula, pelas contribuições no exame de qualificação e pela disponibilidade em ajudar sempre que solicitada.

À Profa. Dra. Cristine do Nascimento Mutti, pela participação e pelas contribuições no exame de qualificação.

A Francis Calais, pelo incentivo ao meu ingresso no mestrado, pelo companheirismo, paciência e apoio incondicional.

A cada entrevistado, por participar e contribuir com a condução dos estudos de caso.

Aos diretores, gerentes e coordenadores dos projetos, por compreenderem a importância de estreitar o relacionamento acadêmico profissional.

A todos que apoiaram e contribuíram com a realização deste trabalho. 
"Por vezes sentimos que aquilo que fazemos não é senão uma gota de água no mar. Mas o mar seria menor se lhe faltasse uma gota."

(Madre Teresa de Calcutá) 


\title{
Gestão de projetos em empreendimentos de infraestrutura: estudo comparativo de construtoras brasileiras e construtoras internacionais atuando no Brasil
}

\begin{abstract}
RESUMO
A atuação de empresas internacionais no setor da construção civil no Brasil tem se tornado cada vez maior e essa atuação exige uma articulação eficiente na gestão dos projetos para seu sucesso. Diante dos desafios do processo de internacionalização, as empresas precisam adaptar-se ao ambiente local, por meio da integração dos conhecimentos, estratégias e processos bem definidos, uma vez que, se as empresas concentrarem-se apenas em um aspecto e negligenciarem o outro, a eficácia dos projetos pode reduzir. O objetivo deste trabalho foi analisar como a gestão de projetos influencia o sucesso dos empreendimentos de infraestrutura executados por empresas brasileiras e empresas estrangeiras, atuantes no mercado de construção civil brasileiro. Essa análise foi elaborada por meio de pesquisa bibliográfica e de seis estudos de caso, nos quais foram entrevistados gerentes dos empreendimentos e coordenadores de projetos de quatro empresas, uma de origem espanhola, uma de origem argentina e duas de origem brasileira. Por meio de um comparativo entre os processos adotados por essas empresas, foi possível identificar os pontos críticos e as dificuldades nos processos de gestão de riscos, gestão do processo de projeto (design), gestão da informação e do conhecimento e gestão da comunicação para execução de empreendimentos. Como resultado, foram propostas diretrizes aos agentes envolvidos, visando à melhoria contínua dos processos adotados. Pretende-se que o resultado desta pesquisa seja útil à definição de referências sobre a internacionalização no mercado da construção civil e as características que devem ser consideradas na gestão de projetos.
\end{abstract}

PALAVRAS-CHAVE: Gestão de projetos. Construção internacional. Sucesso. 


\title{
Project management in infrastructure projects: Brazilian and foreign construction companies operating in Brazil case studies
}

\begin{abstract}
The performance of international companies in the civil construction sector in Brazil has grown significantly and this requires an efficient articulation in the project management for its success. The companies need to adapt to the local environment by integrating knowledge, strategies and well-defined processes due to the challenges of this process, since, if the companies focus only on one of these aspects and neglect others, their projects performance may reduce. The aim of this paper is to analyze how project management impacts on the success of infrastructure projects executed by Brazilian and foreign companies operating in the Brazilian civil construction. This analysis has been developed through literature review and case studies, in which, project managers and project coordinators of four companies, one of Spanish origin, one of Argentine origin and two of Brazilian origin were interviewed. Through a comparison of the processes adopted by these companies, it was possible to identify the critical points and difficulties in the processes regarding risk management, design process management, information and knowledge management, and communication management for the project execution. As a result, guidelines were proposed to the agents involved, aiming the continuous improvement of the processes adopted. The research results shall be useful to the definition of references on internationalization in the construction sector and the characteristics that should be considered in project management.
\end{abstract}

KEYWORDS: Project management. International construction. Project success. 


\section{LISTA DE FIGURAS}

Figura 1 - Nível de alinhamento entre projeto e estratégia ..................................30

Figura 2 - Grau de oportunidade em função do tempo ..........................................43

Figura 3 - Número de artigos publicados por ano ..............................................54

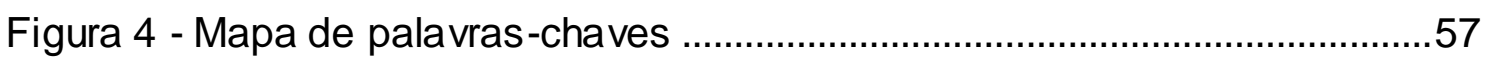

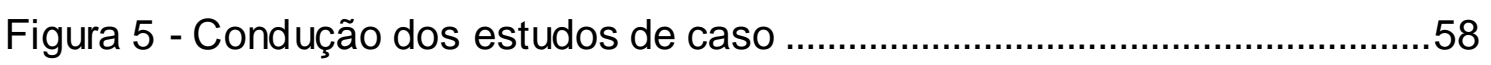

Figura 6 - Organog rama da empresa A .........................................................62

Figura 7 - Organog rama dos projetos da empresa A ..........................................64

Figura 8 - Fluxograma de projetos da empresa $A$.............................................

Figura 9 - Detalhe do projeto de armação …………………………………...... 71

Figura 10 - Armação executada conforme projeto ……………………………....71

Figura 11 - Detalhe do projeto de arquitetura da fachada ....................................73

Figura 12 - Detalhe do projeto de estruturas da fachada ......................................73

Figura 13 - Organograma da empresa B ........................................................78

Figura 14 - Organograma dos projetos da empresa B …………………….......79

Figura 15 - Fluxograma de projetos da empresa B .........................................83

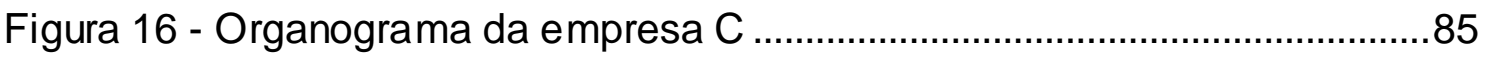

Figura 17 - Organograma dos projetos da empresa C .....................................8

Figura 18 - Organograma da equipe de projetos da empresa $C$.........................91

Figura 19 - Fluxograma de projetos da empresa $C$.............................................92

Figura 20 - Organograma da empresa D .........................................................96

Figura 21 - Organograma dos projetos da empresa D .....................................99

Figura 22 - Organograma da equipe de projetos da empresa $D$......................103

Figura 23 - Fluxograma de projetos da empresa D ..........................................104 


\section{LISTA DE QUADROS}

Quadro 1 - Pesquisas sobre internacionalização da construção .........................18

Quadro 2 - Dificuldades no processo de internacionalização .............................27

Quadro 3 - Características do processo de internacionalização ..........................28

Quadro 4 - Definições de risco ........................................................................33

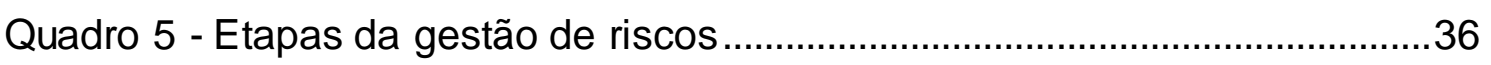

Quadro 6 - Estrutura analítica dos riscos ...........................................................

Quadro 7 - Estratégia para resposta aos riscos ……………………………...39

Quadro 8 - Caracterização dos estudos de caso.................................................59

Quadro 9 - Matriz de oportunidades dos projetos da empresa A .......................67

Quadro 10 - Matriz de riscos dos projetos da empresa A ..................................68

Quadro 11 - Categorias de incertezas da empresa D ......................................100

Quadro 12 - Síntese da gestão de riscos........................................................111

Quadro 13 - Síntese da gestão do processo de projeto ....................................112

Quadro 14 - Síntese da gestão da informação e do conhecimento .................113

Quadro 15 - Síntese da gestão da comunicação ...............................................114 


\section{LISTA DE TABELAS}

Tabela 1 - Classificação das empresas de construção civil quanto a receita ....20 Tabela 2 - Classificação das empresas de construção civil quanto a segmento e

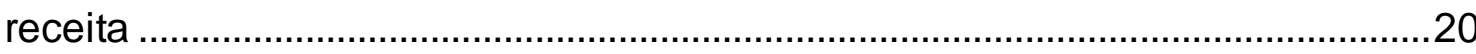

Tabela 3 - Problemas que ocorrem com maior frequência nos projetos ............50

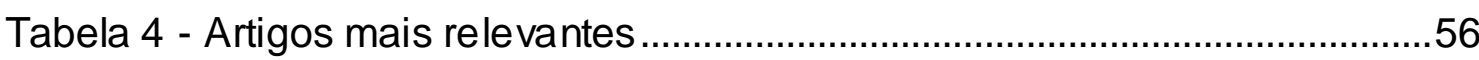

Tabela 5 - Propostas para execução do projeto B1 ……………………….......78

Tabela 6 - Análise de riscos dos projetos ..........................................................

Tabela 7 - Funcionários por nacionalidade ........................................................97

Tabela 8 - Matriz de risco dos projetos da empresa D ......................................101

Tabela 9 - Caracterização dos estudos de caso ...................................................107 


\section{LISTA DE ABREVIATURAS E SIGLAS}
AIF
ArticleText Citation
BNDES Banco Nacional de Desenvolvimento Econômico e Social
CBIC Câmara Brasileira da Indústria da Construção
CQP Controle de Qualidade do Projeto
EAP Estrutura Analítica do Projeto
EPC Engineering, Procurementand and onstruction
FCS Fatores Críticos de Sucesso
GC Gestão do Conhecimento
IED Investimento Estrangeiro Direto
JCRIF Journal Citation Reports Impact Factor
KOM Kick-Off-Meeting
KPMG Klynveld Peat Marwick Goerdeler
MASS Meio Ambiente, Saúde e Segurança do Trabalho
MDIC Ministério do Desenvolvimento, Indústria e Comércio Exterior
OUCAE Operação Urbana Consorciada Água Espraiada
PAC Programa de Aceleração do Crescimento
PIB Produto Interno Bruto
PMI Project Management Institute
QSMS Qualidade, Segurança, Meio ambiente e Saúde
SINICON Sindicato Nacional da Indústria da Construção Pesada
SSTMA Saúde, Segurança do Trabalho e Meio Ambiente 


\section{SUMÁRIO}

1. INTRODUÇÃO

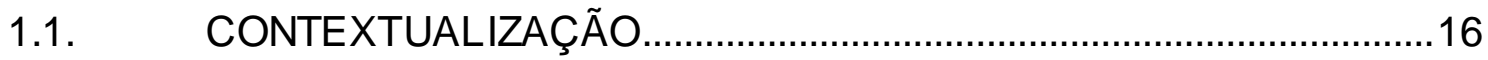

1.2. JUSTIFICATIVA .............................................................................

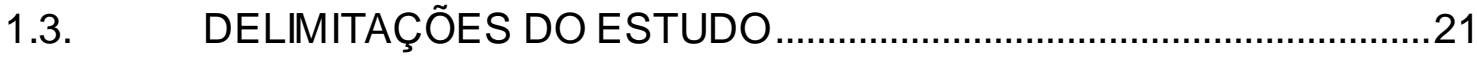

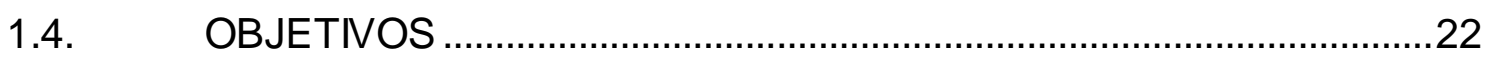

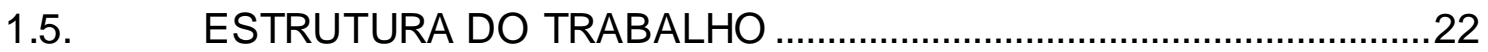

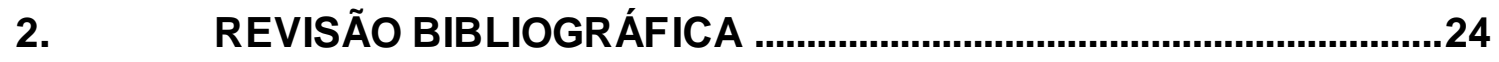

2.1. PROCESSO DE INTERNACIONALIZAÇÃO DE EMPRESAS..........24

2.1.1. Oportunidades e Dificuldades para se internacionalizar.............26

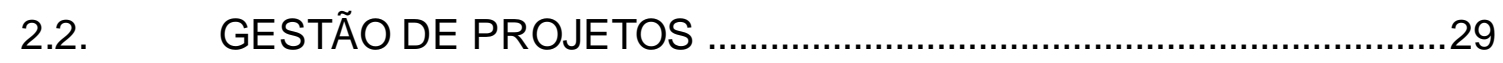

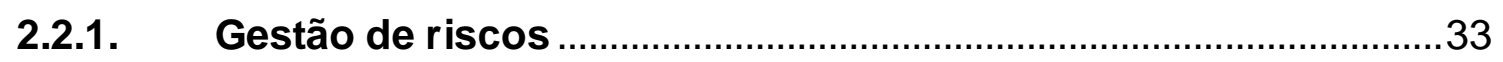

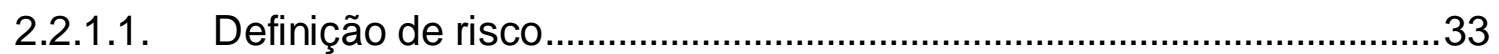

2.2.1.2. Processos de gestão de riscos.........................................................35

2.2.2. Gestão do processo de projeto (design) ……………………….....40

2.2.2.1. Projeto do produto e projeto para produção ........................................40

2.2.2.2. Compatibilização de projetos ................................................................42

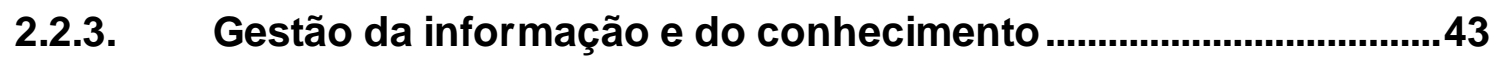

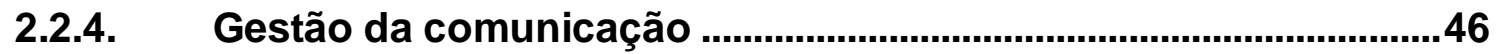

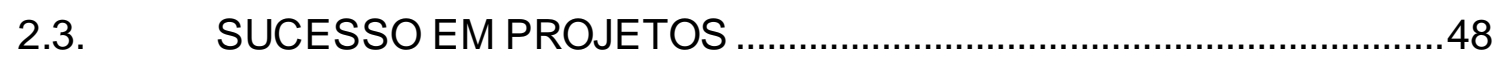

2.4. CONS IDERAÇÕES FINAIS DA REVISÃO BIBLIOGRÁFICA ...........51

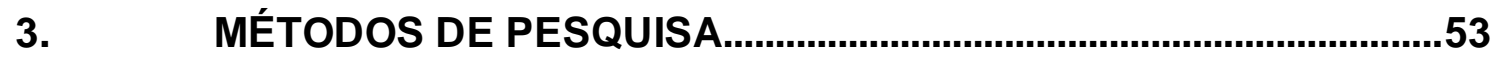

3.1. PESQUISA TEÓRICA ……………………......................................

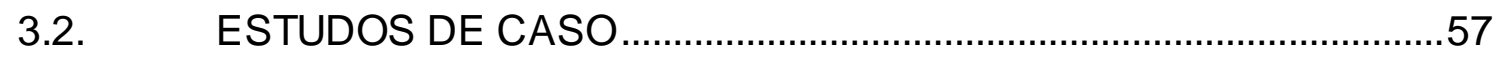

4. APRESENTAÇÃO E ANÁLISE DOS RESULTADOS.......................61

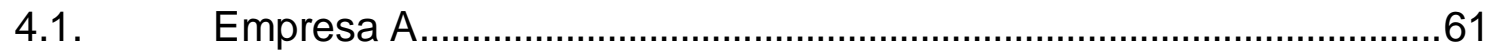

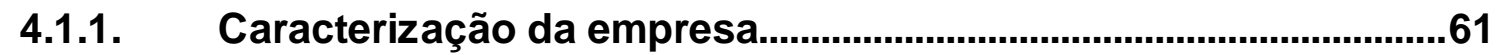

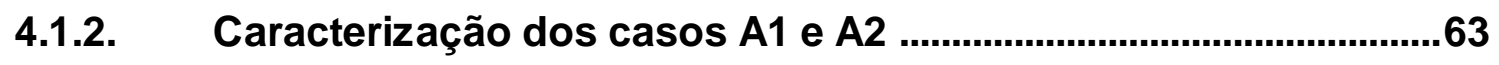

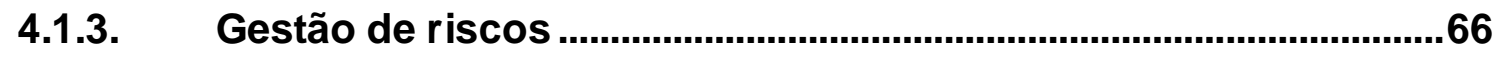




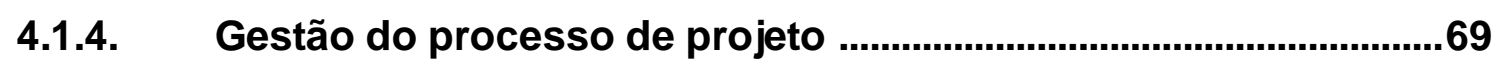

4.1.5. Gestão da informação e do conhecimento .....................................74

4.1.6. Gestão da comunicação ……………….....................................75

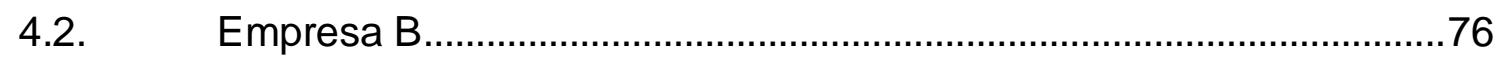

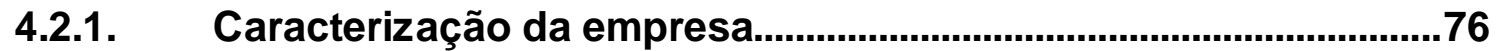

4.2.2. Caracterização do caso B1 .........................................................77

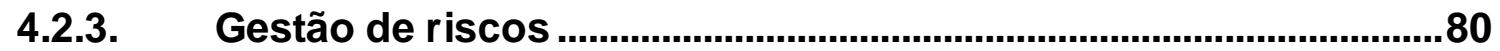

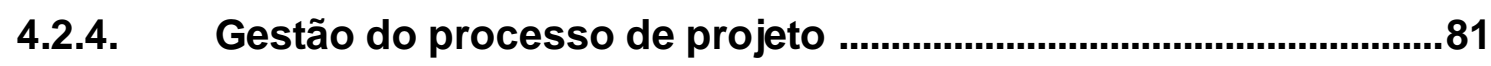

4.2.5. Gestão da informação e do conhecimento .......................................

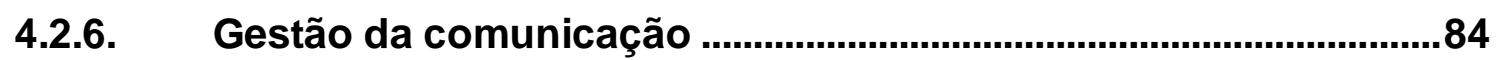

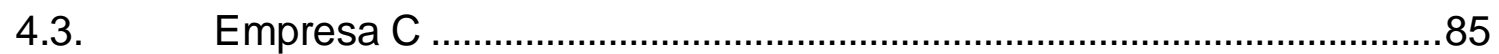

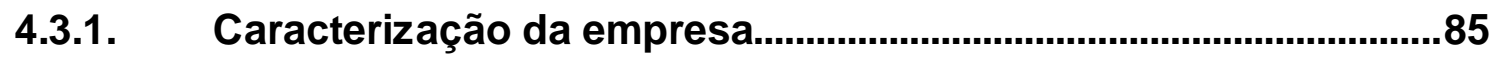

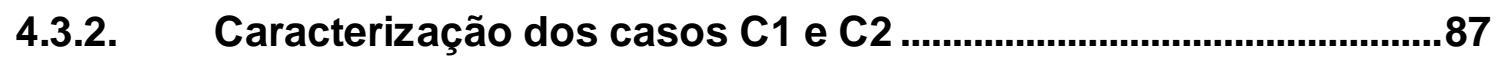

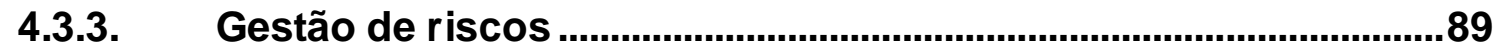

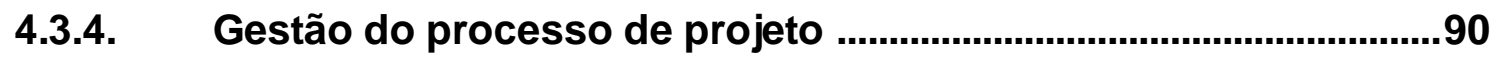

4.3.5. Gestão da informação e do conhecimento .....................................93

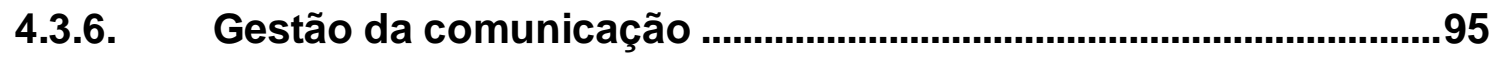

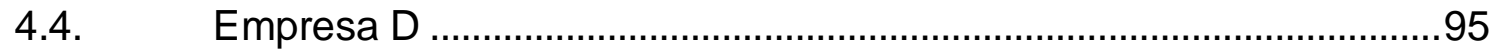

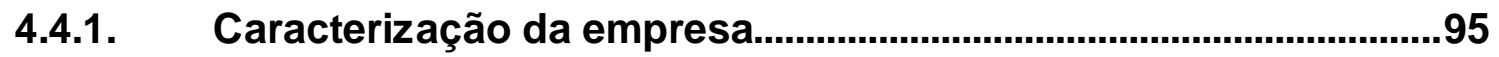

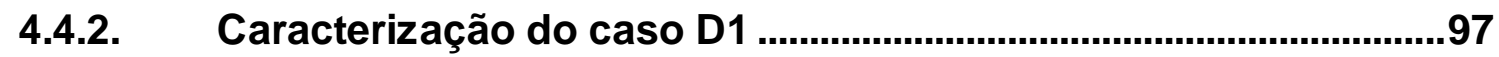

4.4.3. Gestão de riscos .....................................................................100

4.4.4. Gestão do processo de projeto …….........................................102

4.4.5. Gestão da informação e do conhecimento ...................................105

4.4.6. Gestão da comunicação …........................................................106

4.5. ANÁLISES DOS ESTUDOS DE CASO …….....................................107

5. CONSIDERAÇÕES FINAIS E RECOMENDAÇÕES .......................118

REFERÊNCIAS BIBLIOGRÁFICAS ..............................................................121

APÊNDICE A - QUESTIONÁRIO DE PESQUISA ........................................130 


\section{INTRODUÇÃO}

Neste capítulo é apresentado o contexto mais amplo em que se insere o estudo, a fim de possibilitar uma melhor compreensão sobre a importância do tema. Em seguida, anuncia-se a justificativa para escolha e exploração do tema. Também são definidos o escopo do estudo e os conceitos teóricos que o delimitam. Dando prosseguimento, explicita-se o objetivo do estudo e as principais contribuições que o trabalho busca prover. Por último, evidencia-se a forma como o trabalho está estruturado.

\subsection{CONTEXTUALZAÇÃO}

Em tempos de grandes mudanças, devido à globalização, tem sido mais frequente que as empresas nacionais considerem a internacionalização de suas operações como estratégia de negócio (FLORIANI; FLEURY, 2012). Segundo Melo (2008), uma das características mais marcantes desse processo é o grande fluxo de informações, decorrentes da aparente redução dos limites territoriais e dos avanços tecnológicos e científicos mundiais.

Nesse contexto, cabe destacar os conceitos de globalização e internacionalização, a fim de aprofundar a compreensão sobre o tema deste trabalho. Para Fleury e Fleury (2016, p. 35), globalização é "um processo pelo qual as barreiras entre fronteiras são reduzidas e aumentam os fluxos financeiros, econômicos, materiais, de informações, conhecimentos, ideias e valores". Já a internacionalização, "um fenômeno relacionado aos agentes que participam da globalização, como empresas e instituições governamentais" (FLEURY; FLEURY, 20016, p. 35). Além disso, esses autores (2016) definem a atuação das empresas em âmbito multinacional, quando estas exercem atividades em dois ou mais países; ou em âmbito global, quando as atividades de internacionalização são exercidas em distâncias geográficas maiores, ou seja, empresas que atuam em diferentes continentes.

De acordo com Rodrigues (2010), uma das estratégias para as empresas ingressarem no mercado internacional é por meio de seus projetos. Ao mesmo 
tempo, a execução de projetos em outro país, introduz uma série de novos desafios gerenciais, tendo em vista que o desempenho de uma empresa no mercado internacional é muito diferente do desempenho no mercado doméstico. A diferença ocorre devido, principalmente, à cultura, ao ambiente macroeconômico, a regulamentos de mercado, a instituições financeiras e a barreiras de entrada, como a concorrência e a preferência por empresas domésticas (JIN et. al, 2013).

Para que um negócio de construção internacional seja viável, diferentes aspectos devem ser analisados: o crescimento e estabilidade do mercado interno da empresa, o crescimento e estabilidade das regiões ou mercados estrangeiros nos quais a empresa opera e os negócios de construção global e sua sustentabilidade. Por isso, as empresas que desejam atuar em mercados estrangeiros devem possuir certos pré-requisitos como: conhecimento corporativo; experiência especializada; capacidade financeira; equipamento, material e suporte trabalhista; e capacidade de gestão (GUNHAN; ARDITI, 2005a)

É importante destacar que, em geral, os trabalhos que abordam a internacionalização de empresas de construção não exploram o aspecto específico da gestão de projetos, mas sim temáticas semelhantes, como apresentado no Quadro 1.

Dessa forma, o processo de gestão de projetos, aplicado nos empreendimentos de empresas internacionais que atuam no Brasil, é um aspecto bastante específico no contexto da globalização em geral. Esse processo envolve uma série de desafios para as empresas e gestores que buscam obter sucesso nesses empreendimentos. Para Carvalho e Rabechini (2015) sucesso em projetos não se restringe à gestão de escopo, tempo e custo, mas envolve aspectos relacionados à informação, ao conhecimento, à comunicação, à satisfação do cliente e à sustentabilidade. Nesse ponto, é necessário entender as diferenças entre os mercados em que se deseja ingressar e os aspectos relacionados à cultura, à economia, aos aspectos sociais, tecnológicos e políticos. Além disso, as estratégias de internacionalização, apesar de ampliarem o portfólio de negócios e possibilitarem aceleração do crescimento, 
também intensificam os riscos para as empresas e seus empreendimentos (YILDIZ et. al, 2014). Rodrigues (2010) aponta que que os projetos internacionais oferecem tanto oportunidades, quanto um significativo grau de risco associado, e acrescenta que uma maior disciplina na aplicação de métodos, processos e técnicas de gestão de projetos, adaptadas ao contexto internacional pode atenuar esses riscos.

Quadro 1 - Pesquisas sobre internacionalização da construção

\begin{tabular}{|l|l|}
\hline \multicolumn{1}{|c|}{ Autor } & \multicolumn{1}{|c|}{ Pesquisa } \\
\hline $\begin{array}{l}\text { Hastak e Shaked (2000) / Dikmen, Birgonul e Han } \\
\text { (2007) / Han, Diekmann e Ock (2005) / Yildiz et. al } \\
\text { (2014) / Deng et al. (2014) }\end{array}$ & $\begin{array}{l}\text { Estudam riscos em projetos de construção } \\
\text { internacionais }\end{array}$ \\
\hline $\begin{array}{l}\text { Chan e Tse (2003) / Mutti (2004) / Gunhan e Arditi } \\
\text { (2005a) / Low, Abdul-Rahman e Zakaria (2015) }\end{array}$ & $\begin{array}{l}\text { Estudam fatores que afetam a construção em } \\
\text { mercados internacionais }\end{array}$ \\
\hline $\begin{array}{l}\text { Ozorhon et. al (2007; 2008; 2010) / Chen e } \\
\text { Messner (2009) / Zhao, Shen e Zuo (2009) }\end{array}$ & $\begin{array}{l}\text { Estudam a estratégia entrada no mercado de } \\
\text { construção internacional }\end{array}$ \\
\hline $\begin{array}{l}\text { Han S.H., Park S.H., Kim D.Y., Kim H., Kang Y.W. } \\
\text { (2007) / Rosenfeld Y. (2014) }\end{array}$ & $\begin{array}{l}\text { Investigam as principais causas para o excesso } \\
\text { de custo de construção no exterior }\end{array}$ \\
\hline Javernick-Will e Scott (2010) & $\begin{array}{l}\text { Analisam a importância do conhecimento } \\
\text { institucional para atuar em projetos globais }\end{array}$ \\
\hline Han et. al (2007) & $\begin{array}{l}\text { Investigam as relações de causa e efeito de } \\
\text { vários fatores que influenciam nos lucros para } \\
\text { projetos de construção internacionais }\end{array}$ \\
\hline
\end{tabular}

Fonte: Elaborado pelo autor

\subsection{JUSTIFICATIVA}

A busca por vantagens competitivas em um cenário que passa por constantes mudanças econômicas, políticas, tecnológicas e ambientais é um comportamento frequente das organizações nos dias atuais. Na indústria da construção civil não poderia ser diferente. Segundo Breitbach (2009), a importância desse setor está relacionada ao forte potencial de gerar empregos, mobilização elevada de recursos financeiros e a possibilidade de contribuir com o dinamismo de outros segmentos como industriais e de serviços.

Um levantamento feito em setembro de 2017 pelo Sindicato Nacional da Indústria da Construção Pesada (Sinicon) em parceria com a LCA Consultores 
mostrou que o Produto Interno Bruto (PIB) da construção civil no Brasil cresceu em torno de 4,5\% de 2010 até 2013, apresentando uma queda nos anos posteriores, até $-6,6 \%$ no primeiro semestre de 2017. Essa queda ocorreu em função de problemas relacionados à interrupção do Programa de Aceleração do Crescimento (PAC); operação lava-jato; alta da inflação e aumento de juros do mercado imobiliário; redução de empréstimos pelo Banco Nacional de Desenvolvimento Econômico e Social (BNDES), dentre outros (DUTRA, 2017).

O Brasil também apresentou uma queda no índice de Investimento Estrangeiro Direto (IED), saindo da 4⿳亠丷a posição em 2013 para a 16 posição em 2017. No entanto, em uma pesquisa feita pela empresa de consultoria AT Keraney em $2017,75 \%$ das empresas estrangeiras consultadas afirmaram que pretendem ampliar seus investimentos nos próximos três anos no Brasil, sendo que em 2016, esse número era de $71 \%$, o que indica que o Brasil continua atraindo investidores estrangeiros. A crise política e econômica que o Brasil enfrenta desde 2014, aliada ao envolvimento em escândalos de corrupção de grandes construtoras nacionais, consideradas tradicionais nesse segmento, pode ter impulsionado o interesse de empresas estrangeiras investirem no mercado da construção civil brasileiro. Para Teixeira e Carvalho (2011), a Construção Civil tem um papel fundamental nos programas de investimento e no novo ciclo de crescimento do país, pelas peculiaridades de sua cadeia produtiva, baixo efeito de importação e elevados efeitos multiplicadores sobre a economia, a renda, o emprego e os tributos.

De acordo com o levantamento realizado pela Câmara Brasileira da Indústria da Construção (CBIC, 2015), as construtoras de médio e grande porte são minoria no Brasil, aproximadamente, $3 \%$. Porém, a receita bruta anual dessas empresas é significativa, aproximadamente, 55\% (Tabela 1). Já a receita anual proveniente dos serviços de infraestrutura representa $34 \%$ da receita bruta anual da construção. Desse percentual, quase a metade são obras de rodovias, de ferrovias, urbanas, de arte especiais, portuárias, marítimas e fluviais (Tabela 2).

Nesse contexto, cabe uma análise sobre os processos adotados para gestão dos projetos de infraestrutura das empresas internacionais que atuam no Brasil e como esses processos influenciam o sucesso dos empreendimentos, 
especialmente, em um período econômico de queda do PIB da construção, do aumento do investimento estrangeiro e da grande importância do segmento de construção para a retomada econômica brasileira.

Tabela 1 - Classificação das empresas de construção civil quanto a receita

\begin{tabular}{|c|c|c|}
\hline \multirow{2}{*}{$\begin{array}{c}\text { Tamanho do estabelecimento por } \\
\text { empregados ativos }\end{array}$} & \multicolumn{2}{|c|}{ Construção Civil } \\
\cline { 2 - 3 } & Empresas ativas & $\begin{array}{c}\text { Receita bruta } \\
\text { anual (1000 R\$) }\end{array}$ \\
\hline De 1 a 4 & 67.059 & 23.318 .699 \\
De 5 a 29 & 52.655 & 72.738 .082 \\
De 30 a 49 & 4.717 & 25.535 .656 \\
De 50 a 99 & 3.606 & 38.159 .106 \\
De 100 a 249 & 2.300 & 51.244 .842 \\
De 250 a 499 & 725 & 36.313 .439 \\
Com 500 e mais & 425 & 105.368 .019 \\
\hline Total & 131.487 & 352.677 .843 \\
\hline
\end{tabular}

Fonte: Banco de Dados - CBIC (2015)

Tabela 2 - Classificação das empresas de construção civil quanto a segmento e receita

\begin{tabular}{|l|c|c|c|}
\hline \multicolumn{1}{|c|}{ Divisões, grupos e classes de atividades } & $\begin{array}{c}\text { Empresas } \\
\text { ativas }\end{array}$ & $\begin{array}{c}\text { Receita bruta } \\
\text { anual (1000 } \\
\text { R\$) }\end{array}$ & $\begin{array}{c}\text { Percentual } \\
\text { de Receita }\end{array}$ \\
\hline 1. Construção de edifícios & 51.752 & 160.828 .294 & $46 \%$ \\
\hline 2. Obras de infraestrutura & 11.820 & 121.630 .360 & $34 \%$ \\
\cline { 1 - 2 } $\begin{array}{l}\text { 2.1. Construção de rodovias, ferrovias, obras } \\
\text { urbanas e obras de arte especiais }\end{array}$ & 2.540 & 54.980 .924 & \multirow{2}{*}{$47 \%$} \\
\cline { 1 - 2 } 2.2. Obras portuárias, marítimas e fluviais & 34 & 2.606 .145 & \\
\cline { 1 - 2 } 3. Serviços especializados para construção & 67.915 & 70.219 .189 & $20 \%$ \\
\hline
\end{tabular}

Fonte: Banco de Dados - CBIC (2015)

Gunhan e Arditi (2005a) destacam que, embora projetos globais ofereçam novas oportunidades de diversificação e expansão de mercado, eles também introduzem riscos antes inexistentes, desde trabalhar em ambientes estranhos até o aumento da concorrência em escala global.

$\mathrm{Na}$ verdade, existem diferenças entre o país de origem e o país anfitrião (GHEMAWAT 2007) e estas podem ser o início de mal-entendidos, atrasos, estouros de orçamento e/ou reputações prejudicadas (ORR; SCOTT 2008), 
especialmente no segmento de construção civil, onde os empreendimentos estão profundamente incorporados na cultura local. Como resultado, para adaptar-se a esse novo ambiente torna-se extremamente necessário o reconhecimento local e o ajuste das práticas de gestão à cultura ali existente, a fim de reduzir o impacto das diferenças e garantir o sucesso global do empreendimento. Além disso, o intercâmbio de conhecimento entre os empreendimentos, a gestão dos projetos de forma eficiente e as medidas estratégias são necessárias para evitar o desperdício de recursos e a repetição de erros, tanto em níveis de empreendimento quanto em níveis organizacionais (CARRILLO; CHINOWSKY, 2006; JAVERNICK-WILL; HARTMANN, 2011).

A importância deste trabalho decorre da dinâmica do mercado internacional que passa por constantes mudanças, onde os gestores das empresas de construção civil entendem a necessidade de desenvolver estratégias e processos de gestão de projetos para obterem sucesso em seus empreendimentos. Mas, ao mesmo tempo, enfrentam dificuldades em função de sua capacidade de concorrência e de resposta rápidas às mudanças das condições de execução desses empreendimentos.

\subsection{DELIMTAÇÕES DOESTUDO}

O estudo está delimitado ao tema de gestão de projetos, em que serão analisadas empresas brasileiras e empresas estrangeiras multinacionais, além de empreendimentos de infraestrutura executados por essas empresas no Brasil.

Como o tema de gestão de projetos envolve muitos processos, cabe evidenciar os processos que serão tratados neste trabalho, tendo em vista o objetivo de cada um deles: a) Gestão de riscos, que visa compreender como ocorre o processo de identificação, classificação, controle e resposta aos riscos que podem impactar os empreendimentos analisados; b) Gestão do processo de projeto (design), que busca analisar os processos de projeto (design) adotados no empreendimento, tais como projeto para produção, compatibilização, distribuição etc.; c) Gestão da informação e do conhecimento, cujo propósito é 
compreender como são tratadas as informações e o conhecimento necessários para execução do empreendimento e organização dos projetos (design); e d) Gestão da comunicação, que tem por intento compreender os processos utilizados para a comunicação entre as partes interessadas do projeto.

O tema de sucesso em projetos, por sua vez, tem por objetivo analisar como a gestão de projetos, sob a ótica dos conceitos apresentados no parágrafo anterior, auxilia na obtenção de sucesso dos empreendimentos das empresas estudadas.

Outro ponto importante é esclarecer que o termo projeto, no sentido design, será tratado apenas nos itens referentes à gestão do processo de projeto (design management). Nos demais, o referido termo deverá ser entendido como project.

\subsection{OBJETIVOS}

O objetivo geral deste trabalho é analisar, por meio de estudos de caso, como a gestão de projetos influencia o sucesso dos empreendimentos de infraestrutura executados por empresas brasileiras e empresas estrangeiras multinacionais atuantes no mercado de construção civil brasileiro. Para tanto, alguns objetivos específicos serão considerados, como: realizar um comparativo entre os processos adotados por essas empresas; identificar e verificar os pontos críticos e dificuldades inerentes aos processos de gestão de riscos, gestão do processo de projeto (design), gestão da informação e do conhecimento e gestão da comunicação; e propor diretrizes aos agentes envolvidos, visando à melhoria contínua dos processos adotados.

\subsection{ESTRUTURA DO TRABALHO}

Esta dissertação está organizada em quatro capítulos. O primeiro é introdutório e aborda a contextualização do tema, a justificativa, a delimitação e os objetivos do trabalho, além da estrutura deste aqui exposta.

O segundo capítulo detalha a revisão bibliográfica realizada, em que são abordados temas sobre o processo de internacionalização de empresas e os 
benefícios e dificuldades encontrados no decorrer desse processo. Em seguida são tratados alguns processos de gestão de projetos como gestão de riscos, gestão do processo de projeto (design), gestão da informação e conhecimento e gestão da comunicação. Alguns conceitos sobre sucesso em projetos também são explicitados. Por último, é descrita uma síntese da revisão bibliográfica.

O terceiro capítulo discorre sobre a pesquisa teórica e os estudos de caso selecionados, com a caracterização das empresas e de cada empreendimento e os processos adotados. Nesse capítulo, também consta o estudo comparativo desses casos.

No quarto capítulo as considerações finais e a conclusão do trabalho são apresentadas. Há também a abordagem das limitações dos resultados, além das perspectivas de continuidade da pesquisa. 


\section{REVISÃO BIBLIOGRÁFICA}

A fim de entender os conceitos relacionados à gestão de projetos no contexto da internacionalização, este capítulo apresenta uma revisão da literatura que aborda o processo de internacionalização de empresas, evidenciando benefícios e dificuldades do mesmo; gestão de riscos, apontando os processos para identificação, avaliação e tratamento dos riscos em um projeto; gestão do processo de projetos (design), expondo algumas práticas para melhoria da interface do projeto com a execução do empreendimento; gestão da informação e do conhecimento; gestão da comunicação; e o sucesso em projetos.

Esse conteúdo servirá de base para a análise dos processos adotados nos empreendimentos das empresas estudadas e para a compreensão da aplicabilidade dos conceitos da literatura.

\subsection{PROCESSO DE INTERNACIONALIZAÇÃO DE EMPRESAS}

O processo de internacionalização das empresas e a decisão de uma empresa em investir em um país estrangeiro possuem considerações bem mais amplas em termos de estratégias, comportamento e economia, se comparadas com a decisão de investimento no próprio país. Em uma ótica bem extensa, a internacionalização pode ser definida como uma forma de realizar movimentações internacionais por meio de uma única empresa ou de grupos de empresas (ROPELATO et al., 2009).Grande parte dessas empresas consideram a internacionalização de suas atividades uma resposta aos desafios diários impostos pelo mercado global, ou seja, representa uma solução para os problemas resultantes da crise econômica global e, quando esse movimento é bem-sucedido, constitui uma vantagem competitiva (SOUSA; AU-YONGOLIVEIRA, 2015)

Conforme publicação do Ministério do Desenvolvimento, Indústria e Comércio Exterior (MDIC, 2011), o processo de internacionalização pressupõe uma série de decisões, como: a definição clara da estratégia de negócios da empresa, o modelo de governança corporativa e o modelo de gestão. A atividade 
exportadora é o resultado de um planejamento estratégico direcionado para o mercado externo que envolve, entre outros, a identificação dos seguintes pontos:

- capacidade exportadora da empresa: física, de recursos humanos e tecnológicos;

- definição do que exportar;

- identificação e análise do mercado alvo, inclusive dos possíveis concorrentes;

- avaliação da situação atual do mercado e das suas perspectivas;

- definição de estratégias mercadológicas; e

- formação de preço para a exportação.

Além disso, a empresa também pode:

- avaliar a possibilidade de formação de consórcios de exportação. Os consórcios de exportação são uma parceria que as empresas fazem, visando ao aumento de escala, à redução de custos e ao melhor atendimento, possibilitando vencer concorrências no exterior;

- buscar informações sobre fontes de financiamentos;

- promover o serviço no exterior por meio da participação em feiras e exposições; e

- formar parcerias estratégicas, no país de origem ou no exterior.

A indústria da construção civil é geralmente considerada como uma indústria localizada devido às suas características, tais como: a construção no local, fabricação one-off e um produto único. Portanto, é mais difícil para as empresas de construção tornarem-se globais e realizarem seus objetivos de internacionalização do que para as empresas de outros segmentos. Como resultado, os problemas envolvidos na melhoria do processo de internacionalização desse setor têm atraído mais atenção nas últimas duas décadas; por exemplo: Ofori, 2003; Low e Jiang, 2003, 2004; Mutti, 2004; Gunhan e Arditi, 2005a, 2005b; Best e Langston, 2006; Ling e Kwok, 2007; Javernick-Will e Scott, 2010; Shen et al., 2017). 
Para se adaptar a um novo mercado, as equipes de projeto precisam adquirir conhecimento institucional local, incluindo o conhecimento cognitivo regulativo, normativo e cultural, para o desenvolvimento dos seus projetos em outro país (JAVERNICK-WILL, 2009; JAVERNICK-WILL; SCOTT, 2010).

Muitos estudos identificaram diferentes determinantes para o sucesso das empresas de construção civil envolvidas em outros mercados: capacidade e apoio financeiro (FLANAGAN, 1994; MUTTI, 2004; GUNHAN; ARDITI, 2005a; LING et al., 2005), redes internacionais (GUNHAN; ARDITI, 2005b), reputação e história (FLANAGAN, 1994; LING et al., 2005; ZHAO; SHEN, 2008), recursos humanos bem treinados (CUERVO; LOW, 2003; FLANAGAN, 1994; GUNHAN; ARDITI, 2005a; LING et al., 2005; ZHAO; SHEN, 2008), fatores culturais e geográficos, legais, fiscais, econômicos e produtivos (MUTTI, 2004) e conhecimento dos sistemas e políticas dos países estrangeiros (FLANAGAN, 1994; DENG et al., 2014; KADRY; OSMAN; GEORGY, 2017). Porém, a pesquisa aponta poucos estudos específicos sobre os impactos da gestão de projetos aplicados a empreendimentos internacionais, especialmente quanto à obtenção de sucesso para esses empreendimentos e para a empresa.

\subsubsection{Oportunidades e Dificuldades para se internacionalizar}

Ao longo dos anos, o movimento de internacionalização de empresas vem se tornando cada vez mais comum, deixando de ser apenas uma escolha por competitividade - para transformar-se em uma questão de sobrevivência em tempos de crise, uma vez que empresas de todo o mundo começam a disputar novos mercados com seus negócios nativos (MATOS; VIANA; OLIVEIRA, 2015). Assim sendo, as empresas começam a enxergar a internacionalização como uma opção viável e lucrativa. Entretanto, esse processo exige planejamento (ROSENFELD, 2014).

De acordo com Matos, Viana e Oliveira, 2015, as oportunidades no processo de internacionalização são inúmeras, porém se deve levar em conta as dificuldades que eventualmente surgem no caminho e que fazem com que a maioria das empresas não obtenha êxito em seus planos de sair do país, levando-as, muitas vezes, à falência. 
As dificuldades enfrentadas pelas empresas no processo de internacionalização são destacas no Quadro 2, conforme apontado por Ofori (2003), Gunhan e Arditi (2005a) e KPMG (2006). Já as características deste processo são destacadas no Quadro 3, em consonância com Gunhan e Arditi (2005a) e KPMG (2006).

Quadro 2 - Dificuldades no processo de internacionalização

\begin{tabular}{|c|c|c|c|}
\hline Categoria & Ofori (2003) & Gunhan e Arditi (2005) & KPMG (2006) \\
\hline Cultural & $\begin{array}{l}\text { Exclusão de empresas estrangeiras } \\
\text { de alguns tipos de trabalho; } \\
\text { Exigência de subcontratar parte do } \\
\text { trabalho, ou formar parcerias com } \\
\text { empresas do país de origem. }\end{array}$ & Diferenças culturais. & $\begin{array}{l}\text { Burocracias locais; Dificuldade na } \\
\text { introdução dos valores da matriz. }\end{array}$ \\
\hline Econômica & $\begin{array}{l}\text { Discriminação de preços em favor } \\
\text { dos empreiteiros locais; } \\
\text { Instabilidade política, econômica e } \\
\text { financeira; Níveis elevados de } \\
\text { impostos e outros encargos para } \\
\text { os empreiteiros estrangeiros; } \\
\text { Restrições cambiais. }\end{array}$ & $\begin{array}{c}\text { Aumentos de taxa de juros; } \\
\text { Competidores estrangeiros } \\
\text { no país anfitrião; Escassez } \\
\text { de recursos financeiros dos } \\
\text { proprietários de projetos; } \\
\text { Flutuações da inflação e da } \\
\text { moeda; Suborno no País } \\
\text { Anfitrião. }\end{array}$ & $\begin{array}{l}\text { Corrupção; Falta de transparência } \\
\text { e instabilidade econômica em } \\
\text { alguns países; Impasses políticos e } \\
\text { religiosos; Volatilidade cambial. }\end{array}$ \\
\hline Técnica & $\begin{array}{c}\text { Desafios de logística dos projetos; } \\
\text { Qualidade baixa e variável de } \\
\text { trabalho local. }\end{array}$ & $\begin{array}{c}\text { Perda de empregados } \\
\text { chave. }\end{array}$ & $\begin{array}{c}\text { Dificuldades na integração de } \\
\text { estratégias, operações, sistemas e } \\
\text { pessoas; Estudos e custos de } \\
\text { planejamento e } \\
\text { implementação; Infra-estrutura; } \\
\text { Mão-de-obra despreparada. }\end{array}$ \\
\hline
\end{tabular}

Fonte: adaptado de Ofori (2003); Gunhan e Arditi (2005a); KPMG (2006)

A internacionalização estabelece uma forma diferente de competição e, por isso, exige maior compreensão desse processo. Em um primeiro momento, os objetivos da empresa, ao iniciar suas operações em outros paíeses, são impulsionados pela possibilidade de obter matéria-prima e mão de obra mais baratas e continuar com suas operações. Em um segundo momento, o intuito é adentrar outros mercados para desenvolver melhor seus produtos e/ou serviços e até mesmo suas estratégias. Por fim, a intenção é manter-se informada sobre movimentos universais, essenciais para a sobrevivência em uma economia globalizada (MATOS; VIANA; OLIVEIRA, 2015). 
Quadro 3 - Características do processo de internacionalização

\begin{tabular}{|c|c|c|}
\hline Categoria & Gunhan e Arditi (2005) & KPMG (2006) \\
\hline Cultural & Histórico da empresa; Rede internacional. & $\begin{array}{c}\text { Diversidade cultural; Domínio do idioma } \\
\text { estrangeiro. }\end{array}$ \\
\hline Econômica & $\begin{array}{c}\text { Aumento da rentabilidade a longo prazo; } \\
\text { Capacidade de aproveitar os programas de } \\
\text { privatização em economias emergentes; } \\
\text { Capacidade de manter o retorno dos } \\
\text { acionistas; Disponibilidade de acordos } \\
\text { internacionais de beneficiários; Força } \\
\text { financeira. }\end{array}$ & $\begin{array}{c}\text { Competitividade internacional; Novos } \\
\text { mercados; Obtenção de recursos financeiros a } \\
\text { taxas mais competitivas; Redução de custos } \\
\text { (mão-de-obra, logística); Valorização do Real } \\
\text { em relação ao Dólar; Valorização e } \\
\text { fortalecimento da marca; Vantagens fiscais. }\end{array}$ \\
\hline Técnica & $\begin{array}{c}\text { Capacidade de aproveitar a globalização e a } \\
\text { abertura dos mercados; Capacidade de } \\
\text { gestão de projetos; Disponibilidade de novas } \\
\text { áreas de serviço; Experiência especializada; } \\
\text { Maiores possibilidades de avanço } \\
\text { tecnológico. }\end{array}$ & $\begin{array}{c}\text { Busca de novos canais de distribuição; } \\
\text { Aprimoramento de eficiência. }\end{array}$ \\
\hline
\end{tabular}

Fonte: adaptado de Gunhan e Arditi (2005a); KPMG (2006)

Gunhan e Arditi (2005) destacam a capacidade de gestão de projetos como uma importante oportunidade no processo de internacionalização de empresas de construção, tendo em vista que projetos internacionais tendem a ser muito complexos, cabendo destacar múltiplos stakeholders, diferentes fontes de recursos financeiros e ideologias políticas. De acordo com esses autores, os projetos internacionais são mais difíceis de gerenciar do que os projetos domésticos, pois os riscos envolvidos são mais numerosos e menos previsíveis, sendo que, em alguns casos, o conhecimento necessário para que esses projetos sejam concretizados requer uma nova geração de gerentes de projetos que sejam tanto empresários quanto técnicos.

Javernick-Will (2013) aponta que as organizações internacionais de construção precisam adaptar-se ao ambiente local, por meio da integração dos conhecimentos, estratégias e processos. Se as organizações concentrarem-se apenas em um aspecto e negligenciarem o outro, a eficácia do projeto pode não ser a esperada. A resposta a essa análise depende de parâmetros específicos do projeto e da organização e de sua estratégia internacional para condução da gestão dos projetos (JAVERNICK-WILL, 2013). 


\subsection{GESTÃO DE PROJETOS}

A execução de projetos tem recebido elevado foco, em função da necessidade de as organizações desenvolverem iniciativas que busquem inovação $e$ vantagem competitiva (SHENHAR; DVIR, 2007). Dessa forma, empreendimentos passaram a representar uma parcela ainda mais significativa dos investimentos das empresas, sendo 0 adequado acompanhamento fundamental para a avaliação do desempenho das organizações e, consequentemente, para o processo de tomada de decisão. Seguindo essa tendência, a gestão de projetos tem sido cada vez mais relacionada à gestão do negócio, e não apenas a uma atividade operacional isolada (BORGES; CARVALHO, 2013).

Assim, a gestão de projetos possui ligação com a competência estratégica da empresa e pode melhorar significantemente a competitividade futura das organizações. Segundo Srivannaboon (2006), o reconhecimento da importância estratégica da gestão de projetos no mundo corporativo está acelerando rapidamente. Uma das razões para isso pode ser a forte crença dos líderes de negócio de que alinhar a gestão de projetos com a estratégia de negócios pode aumentar potencialmente $o$ alcance dos objetivos organizacionais, da estratégia e do desempenho da empresa. No cenário atual, de alta competitividade e clientes de grande porte, é cada vez mais importante a gestão profissional de projetos nas empresas para que os resultados estejam integrados com as estratégias de negócio (ALMEIDA; FARIAS FILHO, 2010).

Porém, conforme os resultados da edição de 2014 do estudo de Benchmarking em Gestão de projetos, elaborado pelo Project Management Institute (PMI), de que participaram 400 organizações, provenientes da Argentina, Brasil, Canadá, Chile, Colômbia, França, México, EUA e Uruguai, é possível concluir que um número considerável, cerca de $28 \%$, de empresas com alto índice de faturamento, acima de 1 bilhão de dólares, não possui projetos alinhados com a estratégia da organização (PMl, 2014). Esse número é ainda maior quando comparado a faturamentos abaixo de 1 milhão de dólares, cerca de $60 \%$ dos entrevistados (Figura 1). 
Figura 1 - Nível de alinhamento entre projeto e estratégia

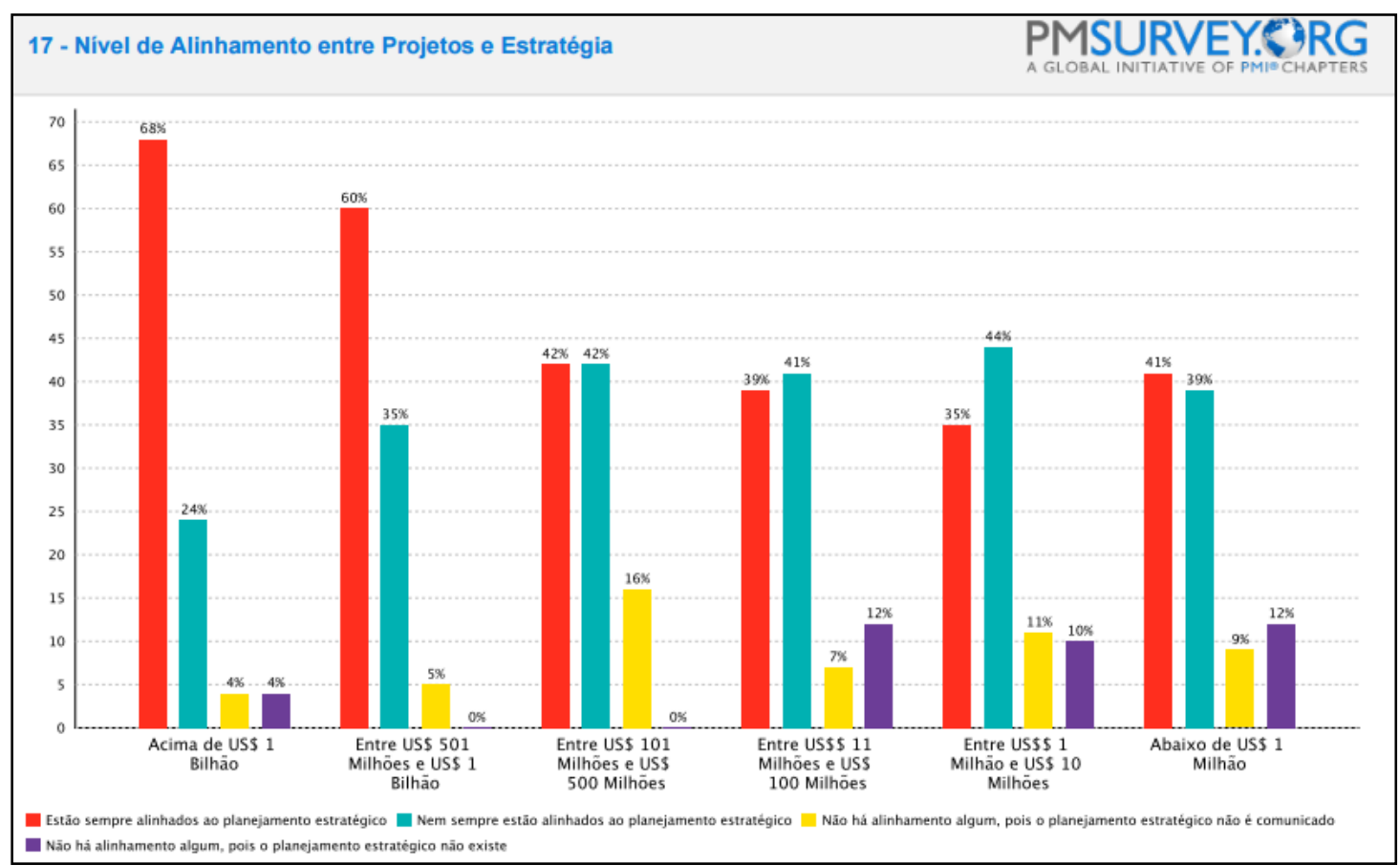

Fonte: PMI 2014

Esse estudo é uma iniciativa do PMI Rio e é realizado no Brasil desde o ano de 2003. Em 2011, tal estudo tornou-se internacional e tem como objetivo avaliar a situação do mercado em relação às práticas de gestão de projetos, além de efetuar comparativos dessa situação entre diferentes países, abordando, entre os assuntos:

- nível de resistência das organizações e o apoio da alta administração à gestão de projetos;

- tipo de estruturas organizacionais utilizadas;

- profissionais dedicados a liderar projetos e qual é o percentual de dedicação de cada um aos projetos;

- principais habilidades necessárias e valorizadas na gestão de projetos;

- principais deficiências dos gerentes de projetos nas organizações;

- nível de utilização de processos para monitoramento do portfólio;

- práticas utilizadas na gestão de porttólio; 
- atividades mais executadas pelos PMOs; e

- principais motivos que levam ao fracasso na implantação de um PMO; entre outros assuntos.

O Estudo de Benchmarking em Gestão de Projetos estuda oito aspectos importantes para identificar o alinhamento das organizações às melhores práticas em Gestão de Projetos: 1) Estrutura Organizacional - analisa as características das estruturas organizacionais existentes, bem como as organizações estão estruturadas para gerenciar seus projetos; 2) Gestão do Portfólio de Projetos - como as Organizações fazem a gestão do seu Portfólio de Projetos, no que diz respeito a práticas, processos, definição de responsabilidades e nível de maturidade; 3) Project Management Office (PMO) - é a verificação de como o Project Management Office (Escritório de Projetos) vem sendo utilizado pelas organizações no suporte ao desenvolvimento de seus projetos, destacando aspectos como estrutura, níveis de reporte, processos e papéis e responsabilidade; 4) Processos e Metodologia - diagnostica como as organizações vêm utilizando boas práticas de Gestão de Projetos. 5) Desenvolvimento Profissional - verifica o grau de adequação das organizações às mais importantes práticas de desenvolvimento profissional, bem como aponta as tendências observadas nas organizações pesquisadas; 6) Ferramentas Tecnológicas - pesquisa quais tecnologias de suporte estão sendo utilizadas pelos profissionais em Gestão de Projetos e organizações e em que extensão podem colaborar para os resultados; 7) Desempenho e Resultados - examina o desempenho e os resultados auferidos pelas organizações no que tange à Gestão de Projetos, identificando os principais problemas, necessidades e fatores críticos de sucesso; e 8) Cultura Organizacional - levanta informações sobre a cultura das organizações em Gestão de Projetos.

Analisando esses fatores é possível entender o quanto as empresas estão culturalmente preparadas para capacitar seus profissionais e desenvolver suas práticas em gestão de projetos, além, também, de saber como esse ambiente é capaz de estabelecer e suportar tais iniciativas. No estudo de benchmarking, realizado no Brasil em 2013, o problema que aparece com maior frequência está relacionado à "comunicação". Esta é apontada como o maior obstáculo 
enfrentado pelas organizações nos anos de 2009, 2011, 2012 e 2013. Já nos anos de 2007, 2008 e 2010 a comunicação é considerada o segundo maior transtorno nas organizações, sendo que o primeiro lugar ficou para o item não cumprimento de prazos (PMl, 2014).

Verifica-se que dificuldade de comunicação vem superando, inclusive, a clássica tríplice restrição: tempo, escopo e custo do projeto. Aliado a essa informação, tem-se a sessão dos benchmarkings - Desenvolvimento Profissional -, no qual as organizações, ao responderem a questão: Principais habilidades necessárias e valorizadas ao gerenciar projetos, elegeram, nos três últimos anos da pesquisa - 2011, 2012 e 2013 -, a comunicação como habilidade mais desejada e valorizada, muito à frente de habilidades como conhecimento técnico e "conhecimento em gestão de projetos", por exemplo. Ressalta-se que, apesar da habilidade liderança ter sido a habilidade mais frequentemente apontada primeiro lugar em 2007, 2008, 2009 e 2010 - verifica-se que a valorização da comunicação vem ocupando o primeiro lugar no ranking nos três últimos anos dos estudos, tendo sido validada em segundo lugar em todos os anos anteriores - 2007, 2008, 2009 e 2010 (PMl, 2014).

O processo de inserção em um novo mercado requer conhecimento local e isso depende de vários parâmetros, tais como: as diferenças percebidas entre o país de origem e o país anfitrião, o tempo decorrido no mercado local, a experiência internacional da organização e a estratégia, quando se trabalha internacionalmente, a disposição de ajustar os processos organizacionais ao novo ambiente e o nível de inserção da empresa em atividades no país local (PETERSEN; PEDERSEN, 2002).

Especificamente no setor da Construção Civil, essa integração ajuda as organizações a melhorarem continuamente, por meio do uso de melhores práticas de Gestão de Projetos, proporcionando resposta rápida ao cliente, redução de retrabalho e inovação por meio do desenvolvimento de novos produtos e serviços (ROBINSON et al., 2001).

Watanuki et al. (2014) apontam que um dos principais desafios à gestão de projetos internacionais reside na integração adequada do projeto em si e suas 
equipes dispersas. Estas, muitas vezes, são originárias da grande diversidade cultural e comportamental de todos os envolvidos no projeto, sendo que esse processo ainda é dificultado por barreiras comunicativas, de compartilhamento de conhecimento e de tomada de decisão inerentes ao contexto internacional.

\subsubsection{Gestão de riscos}

\subsubsection{Definição de risco}

Conforme demonstrado, a seguir, no Quadro 4, não existe uma definição única de risco e vários guias e padrões fornecem suas próprias definições para esse conceito (LOWE, 2013).

Quadro 4 - Definições de risco

\begin{tabular}{|c|c|l|}
\hline Ano & Autor & \multicolumn{1}{c|}{ Definição } \\
\hline 2000 & BS6079:3 & $\begin{array}{l}\text { Incerteza inerente aos planos e a possibilidade de algo } \\
\text { acontecer (ou seja, uma contingência) que pode afetar as } \\
\text { perspectivas de alcançar os objetivos do negócio ou } \\
\text { projeto. }\end{array}$ \\
\hline 2009 & PRINCE2 & $\begin{array}{l}\text { TM } \\
\text { ne evento incerto que, se ocorrer, terá um efeito positivo ou } \\
\text { negativo sobre um objetivo de projeto. }\end{array}$ \\
\hline 2009 & ISO 31000 & $\begin{array}{l}\text { Efeito da incerteza nos objetivos, onde efeito é um desvio } \\
\text { do que era esperado e incerteza é o estado de deficiência } \\
\text { de informações relacionadas com a compreensão ou o } \\
\text { conhecimento de um evento, sua consequência ou } \\
\text { probabilidade. }\end{array}$ \\
\hline 2010 & $\begin{array}{l}\text { Associação para a } \\
\text { Gestão de Projetos } \\
\text { (APM) }\end{array}$ & $\begin{array}{l}\text { Combinação da probabilidade ou frequência de ocorrência } \\
\text { de uma ameaça ou uma oportunidade definida e a } \\
\text { magnitude das consequências da ocorrência. }\end{array}$ \\
\hline 2015 & PMBoK & $\begin{array}{l}\text { Um evento ou condição incerta que, se ocorrer, tem um } \\
\text { efeito positivo ou negativo nos objetivos de um projeto. }\end{array}$ \\
\hline
\end{tabular}

Fonte: Adaptado de Lowe (2013)

Em muitos casos, o conceito de risco é confundido com o conceito de incerteza. Contudo, risco e incerteza podem facilmente ser separados e definidos individualmente. Incerteza diz respeito às situações em que não existem dados estatísticos que suportem determinado acontecimento, não sendo possível prever o mesmo. Risco, pelo contrário, pode ser usado nas circunstâncias em 
que o sucesso ou falha é determinado probabilisticamente por meio de dados anteriores. Assim, a incerteza representada quantitativamente deixa de ser considerada incerteza para passar a ser utilizada como risco (OZTAS; OKMEN, 2005).

Devido às suas características próprias, a construção civil apresenta-se muito diferente das outras indústrias. Isto acontece porque cada projeto que se inicia é tratado como um projeto praticamente novo, não havendo, muitas vezes, repetição das características dos empreendimentos. Além disso, na engenharia civil, reiteradamente o local onde se desenvolve o projeto é diferente do local de execução da obra, o que por si só cria incertezas que podem condicionar a qualidade final do empreendimento. Revela-se ainda o fato de, nessa área, o trabalho ser realizado em condições adversas, em virtude da fase de construção se processar em contato com o meio externo, o que expõe as pessoas, os materiais, os equipamentos e a própria obra, a intempéries que podem causar danos e, consequentemente, atrasos e desvios de custos. Outra característica importante é a participação de profissionais de áreas distintas, como produção, qualidade, engenharia etc., o que origina conflitos, quebra de informações e dificuldades de comunicação. Essas características, como muitas outras, tornam a construção civil, uma área muito exposta ao risco (SILVA, 2009).

Dessa forma, no domínio da construção, tem mais sentido e é mais consistente o uso do termo risco em detrimento ao termo incerteza, pois, nos projetos, valores probabilísticos podem ser usados de forma intuitiva ou baseados em dados obtidos por meio de situações anteriores que, assim, retiram o total desconhecimento e, consequentemente, a incerteza aos projetos de construção (OZTAS; OKMEN, 2005).

Quando se fala de construção em diferentes países, os riscos tendem a ser ainda maiores. Para Mutti, Araújo e Flanagan (2006) as principais categorias de riscos para atuação de empresas de construção no mercado internacional são: riscos tecnológicos, riscos de construção, riscos de operação, riscos de suprimentos, riscos de renda, riscos financeiros, riscos ambientais, riscos políticos, riscos legais e de flutuação de moeda estrangeira. 
No entanto, existem sempre situações que não foram previstas e sobre as quais é necessário atuar, para que os objetivos finais não sejam alterados. Para Silva (2009), as situações de imprevisto, assim como a complexidade dos projetos e a exigência cada vez maior dos clientes, tornam essenciais o estudo e a análise dos riscos. De acordo com essa autora, as consequências dos riscos mais alarmantes na gestão de empreendimentos, são:

- orçamento maior do que o previsto inicialmente;

- prazo maior do que o previsto inicialmente; e

- qualidade inferior ao acordado com o cliente.

Silva (2009) ressalta ainda que, para evitar ou mitigar situações de risco, se deve optar pela implantação dos processos de gestão de riscos em uma fase preliminar do empreendimento. Essa atitude permitirá identificar os riscos em tempo, para que seja possível analisar e definir estratégias de resposta para esses riscos.

Nesse contexto, Xia e Chen (2011) destacam a importância de conhecer os processos e saber utilizar as ferramentas para gestão de risco, visto que é fundamental para que os empreendimentos sejam concluídos com sucesso. $O$ desafio para os gestores está na escolha do método mais adequado para cada projeto a ser executado.

\subsubsection{Processos de gestão de riscos}

De acordo com Kululanga e Kuotcha (2010), para suprir as consequências de mudanças no ambiente de negócios da construção, é necessário seguir uma série de etapas que mapeiam o processo de gestão de riscos do empreendimento, conforme apresentado no Quadro 5.

Cabe ressaltar que Keeling (2002) referenda que, na primeira etapa, os riscos em empreendimentos podem ter origem: 
- no próprio projeto: como por exemplo a escolha do método construtivo, a escolha dos parceiros e subcontratados, além de decisões sobre investimentos e as estratégias adotadas;

- em ocorrências não planejadas: sinistros (acidentes, incêndio, sabotagem etc.). Em alguns casos, essas ocorrências poderão estar cobertas por seguro; e

- em causas externas: falta de empenho por parte do cliente, em função de instabilidade política para o caso de obras públicas ou falta de financiamento para o caso de obras privadas, problemas ambientais, desapropriação de áreas etc.

Quadro 5 - Etapas da gestão de riscos

\begin{tabular}{|c|c|c|}
\hline Etapa & Descrição & Definição \\
\hline 1 & Identificação de riscos & $\begin{array}{l}\text { Identificar os principais fatores que podem impactar o resultados do } \\
\text { empreendimento. }\end{array}$ \\
\hline \multirow{3}{*}{2} & Análise de riscos & $\begin{array}{l}\text { Avaliar a probabilidade e o impacto dos riscos para determinar sua } \\
\text { influência no empreendimento. }\end{array}$ \\
\hline & Priorização de riscos & $\begin{array}{l}\text { Descrever todos os riscos identificados em uma hierarquia particular, } \\
\text { conforme a ordem de importância para o empreendimento. }\end{array}$ \\
\hline & $\begin{array}{l}\text { Plano de contingência } \\
\text { de riscos }\end{array}$ & $\begin{array}{l}\text { É uma ação que visa atribuir valor para o risco, com objetivo de } \\
\text { mitigar o impacto no custo ou tempo, caso esse risco ocorra. }\end{array}$ \\
\hline \multirow{2}{*}{3} & Abordagem sistêmica & $\begin{array}{l}\text { Envolve uma análise mais ampla do risco, primeiramente examinando } \\
\text { toda a cadeia de execução do emprendimento e, em seguida, os } \\
\text { impactos desse risco em setores isolados. }\end{array}$ \\
\hline & $\begin{array}{l}\text { Ações de prevenção } \\
\text { contra os riscos }\end{array}$ & $\begin{array}{l}\text { Após quantificar e qualificar os riscos, é necessário atribuir uma } \\
\text { resposta para cada risco, a saber: evitar, transferir, mitigar, acietar, } \\
\text { explorar, melhorar e compartilhar. }\end{array}$ \\
\hline \multirow{3}{*}{4} & Monitoramento de riscos & $\begin{array}{l}\text { São ações para monitorar os riscos conhecidos, identificar novos } \\
\text { riscos, reduzir riscos e avaliar a eficácia de redução de riscos. }\end{array}$ \\
\hline & $\begin{array}{l}\text { Reavaliação contínua de } \\
\text { riscos }\end{array}$ & $\begin{array}{l}\text { São ações de revisões periódicas dos riscos indetificados, } \\
\text { identificação de novos riscos, mudanças nas probabilidades ou } \\
\text { impactos e mudanças no plano de gestão de riscos do } \\
\text { empreendimento. }\end{array}$ \\
\hline & $\begin{array}{l}\text { Aplicação de } \\
\text { ferramentas de Gestão } \\
\text { de Qualidade Total } \\
\text { (GQT) }\end{array}$ & $\begin{array}{l}\text { Essa etapa visa superar as deficiências de gestão específicas na } \\
\text { análise e controle dos riscos do empreendimento. }\end{array}$ \\
\hline
\end{tabular}

Fonte: Adaptado de Kululanga et Kuotcha (2010)

Para Carvalho e Rabechini (2015) a etapa de identificação dos riscos é crítica, tendo em vista que, apenas os riscos conhecidos podem ser equacionados. Assim, mesmo que as etapas seguintes sejam bem conduzidas, se os riscos não forem devidamente identificados, o projeto estará descoberto contra eles. Uma 
forma simples de identificar e categorizar os riscos é separá-los por grupos de ocorrências.

O quadro 6 apresenta a estrutura analítica dos riscos associados à construção civil categorizados segundo Mahendra et al. (2013).

Quadro 6 - Estrutura analítica dos riscos

\begin{tabular}{|c|c|c|c|c|c|c|}
\hline \multicolumn{7}{|c|}{ Tipo de riscos } \\
\hline Técnicos & Construção & Físicos & Organizacionais & Financeiros & Sócio-políticos & Ambientais \\
\hline $\begin{array}{l}\text { Projeto } \\
\text { incompleto }\end{array}$ & $\begin{array}{l}\text { Produtividade } \\
\text { do trabalho }\end{array}$ & $\begin{array}{l}\text { Danos à } \\
\text { estrutura }\end{array}$ & $\begin{array}{l}\text { Relações } \\
\text { contratuais }\end{array}$ & $\begin{array}{l}\text { Aumento do } \\
\text { custo de } \\
\text { material }\end{array}$ & $\begin{array}{l}\text { Mudanças nas } \\
\text { leis e } \\
\text { regulamentos }\end{array}$ & $\begin{array}{l}\text { Desastres } \\
\text { naturais }\end{array}$ \\
\hline $\begin{array}{l}\text { Especificação } \\
\text { inadequada }\end{array}$ & $\begin{array}{l}\text { Conflitos } \\
\text { trabalhistas }\end{array}$ & $\begin{array}{c}\text { Danos ao } \\
\text { equipamento }\end{array}$ & $\begin{array}{l}\text { Experiência do } \\
\text { empreiteiro }\end{array}$ & $\begin{array}{l}\text { Baixa demanda } \\
\text { de mercado }\end{array}$ & $\begin{array}{l}\text { Regras de } \\
\text { poluição e } \\
\text { segurança }\end{array}$ & $\begin{array}{c}\text { Implicações } \\
\text { meteoroló- } \\
\text { gicas }\end{array}$ \\
\hline $\begin{array}{c}\text { Investigação } \\
\text { inadequada do } \\
\text { local }\end{array}$ & $\begin{array}{l}\text { Condições } \\
\text { locais }\end{array}$ & $\begin{array}{l}\text { Lesões de } \\
\text { trabalho }\end{array}$ & $\begin{array}{l}\text { Atitude dos } \\
\text { participantes }\end{array}$ & $\begin{array}{l}\text { Flutuações da } \\
\text { taxa de câmbio }\end{array}$ & $\begin{array}{l}\text { Suborno / } \\
\text { Corrupção }\end{array}$ & \\
\hline $\begin{array}{l}\text { Mudança no } \\
\text { escopo }\end{array}$ & $\begin{array}{l}\text { Falhas nos } \\
\text { equipamentos }\end{array}$ & $\begin{array}{c}\text { Equipamento e } \\
\text { material de } \\
\text { incêndio e roubo }\end{array}$ & $\begin{array}{c}\text { Força de trabalho } \\
\text { inexperiente }\end{array}$ & $\begin{array}{l}\text { Estimativa } \\
\text { inadequada de } \\
\text { atrasos de } \\
\text { pagamento }\end{array}$ & $\begin{array}{c}\text { Barreira } \\
\text { cultural/de } \\
\text { linguagem }\end{array}$ & \\
\hline $\begin{array}{l}\text { Procedimentos } \\
\text { de construção }\end{array}$ & $\begin{array}{c}\text { Mudanças no } \\
\text { projeto }\end{array}$ & & Comunicação & Impostos & $\begin{array}{c}\text { Lei e ordem de } \\
\text { guerra e } \\
\text { desordem civil }\end{array}$ & \\
\hline \multirow[t]{2}{*}{$\begin{array}{l}\text { Disponibilidade } \\
\text { insuficiênte de } \\
\text { recursos }\end{array}$} & $\begin{array}{c}\text { Padrão muito } \\
\text { alto de } \\
\text { qualidade }\end{array}$ & & & & $\begin{array}{c}\text { Requerimento } \\
\text { de autorização e } \\
\text { aprovação }\end{array}$ & \\
\hline & $\begin{array}{c}\text { Nova } \\
\text { tecnologia }\end{array}$ & & & & & \\
\hline
\end{tabular}

Fonte: Mahendra et al. (2013)

Depois de identificados os riscos, segue-se para a segunda etapa, a de análise dos riscos. Este processo sistemático consiste em perceber a natureza dos riscos e quantificá-los, obtendo um grau de importância para cada um deles. $\mathrm{O}$ nível de risco é conseguido por intermédio da combinação das consequências e da probabilidade dos fatores de risco. A avaliação dos riscos pode ser efetuada segundo diferentes níveis de detalhe, dependendo dos tipos de riscos, do objetivo da avaliação e da informação disponível (CARVALHO; RABECHINI, 2015). Os dois tipos de análise dos riscos mais usuais são:

- análise qualitativa: avalia a prioridade dos riscos identificados usando a sua probabilidade relativa ou plausibilidade de ocorrência e o impacto correspondente nos objetivos do projeto se os riscos ocorrerem. Essa análise também pode considerar outros fatores como: o intervalo de 
tempo para resposta; a tolerância a riscos da organização; as restrições de custo, cronograma, escopo e qualidade do projeto;

- análise quantitativa: esse processo caracteriza-se pela utilização de valores numéricos na definição das consequências e probabilidade dos riscos. Essa caracterização baseia-se em dados registrados na análise qualitativa. As consequências e a probabilidade dos riscos, assim como a combinação para obter o nível de risco, podem ser expressas de várias formas; o modo de retratá-las varia de acordo com o tipo de risco avaliado e com os objetivos da avaliação do risco.

De acordo com Carvalho e Rabechini (2015), o conjunto dessas duas análises fornece dados mais confiáveis para as tomadas de decisão do projeto. No entanto, nem sempre é possível fazê-las, tendo em vista que ambas dependem de uma boa quantidade de dados históricos, softwares próprios e pessoas capacitadas para conduzi-las. Além disso, cabe ao gerente de projetos definir como essa etapa será conduzida.

Na terceira etapa do processo de gestão de riscos, procura-se adotar medidas que possam reduzir os impactos dos riscos negativos para os objetivos do projeto, agindo de forma oposta para o caso de riscos positivos (CARVALHO; RABECHINI, 2015). Essas medidas são chamadas de resposta ao risco. De acordo com o PMI (2013), existem muitas opções de reposta ao risco, que variam para o caso de risco positivo ou negativo, de forma estratégica para cada empreendimento, conforme se pode perceber pelo Quadro 7.

Sobre a estratégia para resposta aos riscos negativos, é importante considerar que a equipe do projeto pode optar em (CARVALHO; RABECHINI, 2015):

- evitar: age para eliminar a ameaça ou proteger o projeto contra o seu impacto;

- transferir: transfere o impacto de uma ameaça para terceiros, juntamente com a responsabilidade pela sua resposta. Nesse caso, o risco simplesmente passa a ser responsabilidade de gestão de outra parte, mas não é eliminado; 
- mitigar: age para reduzir a probabilidade de ocorrência ou impacto do risco. Implica na redução da probabilidade e/ou do impacto de um evento de risco adverso para dentro de limites aceitáveis; e

- aceitar: reconhece a existência do risco e não age, a menos que o risco ocorra e seja comum tanto para riscos positivos quanto para negativos.

Quadro 7 - Estratégia para resposta aos riscos

\begin{tabular}{|c|c|}
\hline \multicolumn{2}{|c|}{ Estratégia para resposta aos riscos } \\
\hline Negativos & Positivos \\
\hline - Evitar & - Explorar \\
\hline - Transferir & - Melhorra \\
\hline - Mitigar & - Compartilhar \\
\hline - Aceitar & - Aceitar \\
\hline
\end{tabular}

Fonte: Adaptado do PMl (2013)

Em se tratando da estratégia para resposta aos riscos positivos, deve-se ter atenção ao fato de que em (CARVALHO; RABECHINI, 2015):

- explorar: elimina-se a incerteza associada com um determinado risco positivo, garantindo que a oportunidade realmente aconteça;

- melhorar: aumenta-se a probabilidade e/ou os impactos positivos de uma oportunidade. Identificar e maximizar os principais impulsionadores desses riscos de impacto positivo pode aumentar a probabilidade de ocorrência; e

- compartilhar: há a alocação integral ou parcial da responsabilidade da oportunidade a um terceiro que tenha mais capacidade de explorar a oportunidade para benefício do projeto.

$\mathrm{Na}$ quarta etapa, ocorre a administração dos riscos, por meio de um monitoramento e controle contínuos. Nessa etapa, segundo Kululanga e Kuotcha (2010), é feita uma análise dos riscos que ocorreram e a forma como foram conduzidos, além da identificação de novos riscos que, possivelmente, podem ocorrer no decorrer da execução do empreendimento. Estes últimos também 
devem ser identificados, avaliados e tratados, retomando o processo desde a primeira etapa.

\subsubsection{Gestão do processo de projeto (design)}

Para Oliveira e Melhado (2008) o processo de projeto está intimamente vinculado ao desempenho geral das empresas de projeto, ou seja, uma boa gestão do processo do projeto contribui de forma positiva para a gestão da empresa de projeto. Esses autores apresentam um modelo de gestão para empresas de projetos divididos em nove fases: Estrutura organizacional; Planejamento estratégico; Planejamento e controle do projeto; Gestão de custos; Gestão comercial; Sistema de informações; Gestão de recursos humanos; Serviços agregados ao projeto; e Avaliação do desempenho.

A fase de planejamento e controle do processo de projeto é crucial, uma vez que é devido a ela que são identificadas e definidas as iterações entre as diversas fases do projeto. Oliveira e Melhado (2008, p. 118) apontam que "para o planejamento e execução do processo de projeto é necessário garantir que os projetistas da empresa tenham, no mínimo, conhecimento básico do instrumental teórico sobre gestão de projetos, de maneira que possam contribuir para a confecção do fluxo geral das atividades que compõem o processo de projeto em sua empresa".

A identificação do modelo de gestão do processo de projeto pode facilitar a compreensão das suas fases com mais clareza e indicar melhorias reais e imediatas na gestão do processo. Uma dessas melhorias está relacionada à qualidade do projeto para produção.

\subsubsection{Projeto do produto e projeto para produão}

O processo de desenvolvimento de produtos pode ser definido como o conjunto de atividades por meio das quais se busca, a partir das necessidades do mercado e das possibilidades e restrições tecnológicas, e considerando as estratégias competitivas e de produto da empresa, chegar às especificações de projeto de um produto e de seu processo de produção, para que a manufatura 
seja capaz de produzi-lo (FARIA et al., 2008). Ainda, o desenvolvimento de produto envolve acompanhamento, após o lançamento, bem como 0 planejamento da descontinuidade do produto no mercado, incorporando esses conceitos na especificação do projeto, atendendo assim, todas as necessidades do produto ao longo do seu ciclo de vida (ROSENFELDet al., 2006).

Oloufa et al. (2004) trabalham o fluxo de informações em projetos, com a finalidade de identificar aquelas mais urgentes dentro do processo de execução e, dessa forma, reduzir incertezas e desvios. Os autores desenvolveram uma matriz de estrutura de projetos que pode ser utilizada, principalmente, para determinar o impacto de certas alterações de características de projeto em outras dependentes. Essa ferramenta fornece uma visão dos projetos de uma maneira fácil e gerenciável. Os autores também destacam que, na execução de projetos para construção, não é incomum estimar alguns parâmetros de projeto com base em dados iniciais e até mesmo históricos, advindos de projetos semelhantes. A abordagem permite iniciar outras atividades de projeto como, por exemplo, em um projeto que envolve a concepção e construção de um hospital, para permitir a aquisição de um componente mecânico, o projetista pode basearse nos dados iniciais para a estimativa do tipo e capacidade do equipamento. Isso possibilita iniciar o processo de aquisição (licitação, desenvolvimento, entrega e instalação). Tal processo pode gerar desvios, em função de dados estimados, sendo que as consequências e o custo de retrabalho, em casos como esse, podem ser muito onerosos. Além disso, existe a possibilidade de impacto em diferentes áreas, responsáveis pela concepção do produto do projeto e que poderão ser, igualmente, prejudicadas.

Para execução de um determinado produto e/ou serviço é necessário o maior número de informações e detalhamentos possíveis, sendo que o projeto é que deve conter esses elementos. O desempenho do projeto durante a fase de execução dos serviços está associado à forma como ele é interpretado pela equipe de produção e, além disto, ao nível de comunicação que o mesmo possui, de nada adianta o projeto ser possuidor de boas técnicas construtivas se estas não forem comunicadas de forma inteligível ao pessoal da execução (NASCIMENTO; FORMOSO, 1998). Assim, é necessário que o projeto contenha 
detalhes executivos que possibilitem as equipes planejar as atividades em função das metodologias definidas. Nesse sentido, Melhado (1994, p. 196) define projeto para produção como:

o conjunto de elementos de projeto elaborados de forma simultânea ao detalhamento do projeto executivo, para utilização no âmbito das atividades de produção em obra, contendo as definições de: disposição e sequência das atividades de obra e frentes de serviço; uso de equipamentos; arranjo e evolução do canteiro; dentre outros itens vinculados às características e recursos próprios da empresa construtora.

Para Oliveira, Fabrício e Melhado (2004) o projeto na construção civil deve informar as características físicas do produto, deve permitir a introdução de inovações tecnológicas, reduzir a existência de problemas patológicos, garantir características de qualidade, racionalidade e construtibilidade do empreendimento, gerando, dessa forma, reflexos positivos na adequação ao uso, redução do lead time de execução da obra e redução dos seus custos finais, ou seja, o projeto não deve ser um produto estimado e não se deve trabalhar em um ambiente de muitas incertezas.

\subsubsection{Compatibilização de projetos}

Na concepção de projetos, em especial aqueles mais complexos, é necessária uma análise minuciosa das diferentes áreas técnicas atuantes. A compatibilização de projetos visa à redução das possíveis falhas que ocorrem na fase concepção até a fase de execução da obra arquitetônica. Para Santos (1998) essa etapa é realizada por meio da sobreposição e da identificação de interferências entre os elementos do projeto.

Melhado (2005) ressalta que na etapa de compatibilização, os projetos de diferentes especialidades são superpostos para verificar as interferências, evidenciar os problemas para que o coordenador possa solucioná-los. De acordo com Mattos (2010), é importante que o gestor intervenha o quanto antes no projeto, uma vez que há um período de oportunidade construtiva, quando as alterações ainda geram baixo custo e baixa perda de produtividade. Neste caso, 
tempo é muito importante, considerando que o grau de oportunidade construtiva e o potencial de agregar valor diminuem em função do tempo (Figura 2).

Figura 2 - Grau de oportunidade em função do tempo

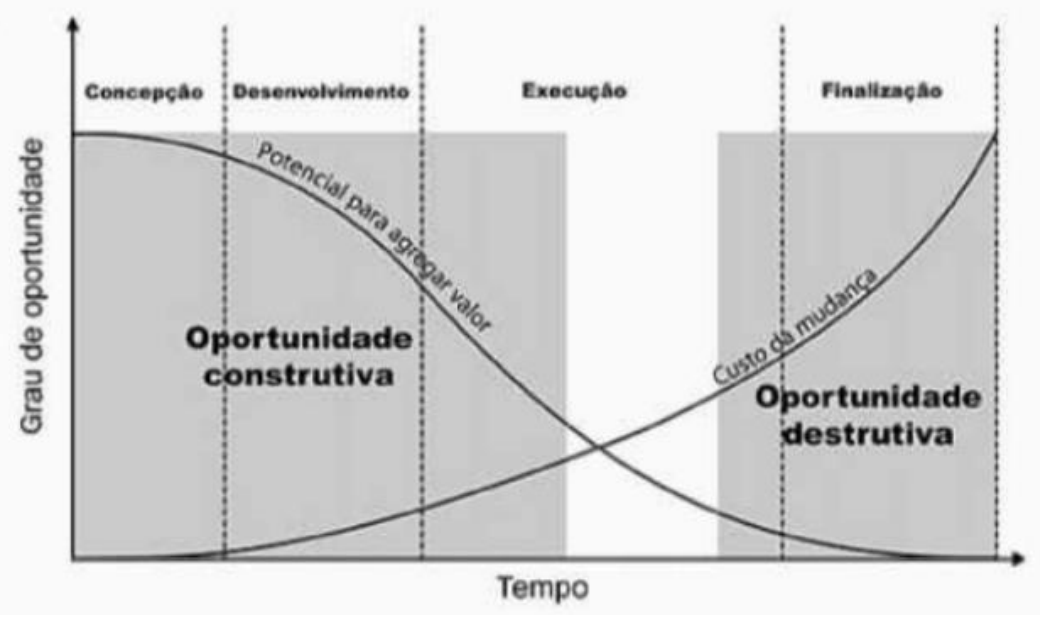

Fonte: Mattos (2010)

Cabe ressaltar que o desenvolvimento de projetos sem a análise da compatibilização pode gerar consequências negativas, tais como, aumento de retrabalho, atraso no cronograma de execução, e falhas na qualidade da obra, que frequentemente conduzem acréscimo de prazo e custos. Considerando esta premissa, a compatibilização de projetos é altamente recomendada como ferramenta de gestão e planejamento, a fim de racionalizar a obra e aumentar a produtividade (SOUSA, 2010).

\subsubsection{Gestão da informação e do conhecimento}

A gestão da informação, ou gestão do conhecimento (GC), é, segundo Perroti e Vasconcellos (2005, p. 4):

o processo de identificar quais conhecimentos são necessários para alavancar as competências essenciais (estratégia); mapear quais destes conhecimentos e competência a organização já dispõe (mapeamento de competências e conhecimentos); aprender os que a organização não sabe e precisa (aprendizagem organizacional); e monitorar 0 ambiente (inteligência competitiva). 
De acordo com Ponchirolli e Fialho (2005) a abordagem de GC surgiu no início da década de 1990 e foi gradativamente incorporada à estratégia das empresas, uma vez que trata da prática de agregar valor à informação e distribuí-la, tendo como principal motivador o aproveitamento dos recursos existentes na empresa. Para esses autores, a GC "enfatiza o capital humano, proporcionando a criação de novas ideias e processos, identificando, captando, distribuindo, compartilhando e alavancando o conhecimento", o que exige a adoção de práticas gerenciais compatíveis com os processos de criação e aprendizado individual e organizacional.

Para Silveira (2004, p. 40) a GC é, em primeiro lugar, "uma nova forma de se trabalhar, uma nova cultura organizacional, na qual o ambiente e os valores permitam gerar a motivação necessária à aprendizagem, ao compartilhamento ou mesmo à transferência e à aplicação do conhecimento". Scharf (2007) defende que GC é o conjunto de processos para a criação, disseminação e uso do conhecimento dentro da empresa, com o objetivo de desenvolver vantagens competitivas sustentáveis por meio da criação de valor compartilhada com o mercado.

Já Valentim (2008, p. 3) cita que a GC "é um conjunto de atividades que visa trabalhar a cultura e a comunicação organizacional", visando um ambiente positivo para criar, adquirir, compartilhar e utilizar o conhecimento em benefício da organização, formalizado, na medida do possível, a fim de transformar 0 conhecimento gerado pelos indivíduos (tácito) em informação (explícito), de modo a subsidiar a geração de ideias, a solução de problemas e o processo decisório em âmbito organizacional.

Os conceitos de Nonaka e Takeuchi (1995), de criação de conhecimento organizacional e conversão de conhecimento, introduzem a noção de conhecimento tácito e explícito. Nonaka e Takeuchi (1997) apresentam os seguintes promotores do conhecimento:

- socialização do conhecimento tácito em conhecimento tácito - processo em que são partilhadas as experiências individuais e coletivas; 
- exteriorização do conhecimento tácito em conhecimento explícito processo que procura tornar explícito e disponível, em alguma forma de registo, o conhecimento de cada um. A escrita é um exemplo dessa forma;

- combinação do conhecimento explícito em conhecimento explícito processo em que as pessoas trocam e sintonizam conhecimentos por intermédio de formas externas, tais como relatórios, documentos e comunicação telefônica; e

- internalização do conhecimento explícito em conhecimento tácito processo em que cada colaborador vai aprender fazendo. Ocorre quando o colaborador consegue assimilar e aplicar o que aprendeu. Por exemplo, a reconfiguração de modelos mentais, a partilha de experiências por intermédio "da socialização, externalização e combinação".

Os trabalhos de Nonaka e Takeuchi foram ampliados, como no trabalho de Von Krogh et al. (2012) que explorou o papel da liderança na criação de conhecimento organizacional, especialmente em contextos de projetos de construção. Von Krogh et al. (2012) propõem uma estrutura teórica que considera a liderança centralizada (encontrada em organizações formais) e a liderança distribuída (encontrada em organizações mais informais), sendo a última, uma característica do setor de construção. Tal estrutura abrange a criação de conhecimento em três estratos de liderança. O primeiro é uma camada estrutural que contempla os processos formais, bem estruturados. $O$ segundo é uma camada de atividade central, que é informal, e onde o conhecimento é criado por meio de contato direto com as pessoas. O terceiro é uma camada que possui atividades de liderança, com a finalidade de conectar as camadas informais e formais.

Valentim (2008) considera que a gestão da informação está relacionada com os fluxos formais do ambiente organizacional, ou seja, o que está sistematizado, formalizado, explicitado em qualquer tipo de suporte (eletrônico, digital, papel etc.). A gestão do conhecimento está relacionada com os fluxos informais, ou seja, o que não está explicitado, formalizado, sistematizado (cultura, comunicação, comportamento, aprendizagem, valores, práticas etc.). Essa 
autora destaca que a gestão do conhecimento alimenta a gestão da informação, que retroalimenta a gestão do conhecimento, em um ciclo contínuo.

Carrillo et al. (2013), destacam que, no ambiente de construção, uma ferramenta comum para identificar melhorias e inovações são as lições aprendidas. No entanto, esse setor provou ser uma área difícil no quesito sucesso, no registro das informações (ANBARI et al., 2008). Existem problemas significativos como, por exemplo, condições de crise econômica, em que as lições são frequentemente "tácitas" e mantidas de forma individual (NONAKA; TAKEUCHI, 1995). E, com a redução de mão de obra, esse aprendizado e compartilhamento de conhecimento tornam-se mais difíceis (PARIS, CROSS, DAVENPORT, 2006).

Nesse contexto, Suresh et al. (2017) afirmam que a GC é inestimável para a gestão de construção, em função da sua contribuição para o aproveitamento e integração do conhecimento, por meio de fronteiras pessoais, organizacionais, de projeto e da indústria. Hope (2000) infere que muitas organizações percebem que o sucesso de longo prazo depende da acumulação e do uso produtivo, baseados no conhecimento. Dessa forma, uma organização que promove a criação e a partilha de conhecimento, tanto tácito quanto explícito, pode ter melhores condições para atuar, de forma dinâmica e estratégica, em diversas áreas e em novos mercados.

\subsubsection{Gestão da comunicação}

A gestão da comunicação é responsável pelo fluxo de informações do projeto, pois constitui, executa, acompanha e controla todas as informações durante o ciclo de vida do mesmo. Segundo Chaves et al. (2006, p. 13) a área de comunicações "é, por excelência, um elemento de apoio fundamental para o acompanhamento de todas as outras áreas da gestão", já que estas necessitam da obtenção, acompanhamento e emissão das informações para todas as partes interessadas do projeto.

De modo particular, a indústria da construção possui um fluxo de informações intensivo e que necessita serem transferidas e trocadas durante o ciclo de vida 
do projeto (CHEN; KAMARA, 2011). Porém, a falta de informação em tempo real é uma característica da indústria da construção civil. Essa falta cria obstáculos e reduz a capacidade dos gestores acompanharem os custos, prazos e demais indicadores de desempenho, diminuindo sua habilidade de detectar ou controlar a variabilidade e incerteza inerentes nas atividades de construção (HOWELL; KOSKELA, 2000).

As informações, em tempo real da execução das atividades, permitem a melhoria contínua dos fluxos de trabalho, e o compartilhamento de dados de construção pode melhorar a transparência de desperdícios nos fluxos de trabalho que não se manifestam de maneira clara (NAKAGAWA, 2006). No entanto, realizar um intercâmbio eficaz de informações entre os participantes de uma construção não é uma tarefa fácil, pois canteiros de obra com grandes áreas, condições climáticas adversas e recursos espalhados tornam difícil aos engenheiros e aos gerentes essa extração da informação do local onde está ocorrendo a atividade até o escritório (KIM; LIM; KIM, 2011).

$\mathrm{Na}$ construção civil, o tratamento do fluxo de informações entre os diversos agentes intervenientes ao longo de todo processo é um dos fatores críticos para o sucesso de um empreendimento (NASCIMENTO; SANTOS, 2008). Nesse ponto, é importante tratar os aspectos que impedem uma boa comunicação. Fox (2001) divide essas barreiras de comunicação em quatro grupos: (1) as ambientais, que enfocam o desconforto físico, barulhos e interrupções ocorridas na rotina diária de uma organização; (2) as verbais, que destacam o uso de siglas e jargões específicos de cada grupo social; (3) as interpessoais, que salientam as suposições incorretas e diferentes percepções, diferenças de linguagem, desconfiança, diferenças de status social, diferenças étnicas etc.; e (4) as reações emocionais, que evidenciam sentimentos como raiva, amor, autodefesa, ódio, medo, vergonha, entre outros.

Santos, Santos e Shibao (2017) destacam que as atividades de gestão, que fazem parte do cotidiano de projetos e empreendimentos de construção, tornamse mais críticas em ambientes internacionais, como, por exemplo: agendamento de reuniões, a forma de comunicação ou o cronograma do projeto. Segundo Crawford et al. (2007), a comunicação é constantemente identificada como um 
dos aspectos da gestão de projetos, mais fortemente influenciado pela mudança cultural.

Para Carvalho e Rabechini (2015) as barreiras de comunicação podem ocorrer devido a fatores como: falta de clareza na mensagem transmitida; mensagem mal formulada; conflitos de interesses; premissas equivocadas; canais inadequados; excesso de informações; presença excessiva de ruídos; ambiente cultural distinto; falta de tempo adequado; ausência de feedback; censura na informação transmitida; irrelevância na informação, entre outras. Para esses autores, o sucesso do projeto depende do esforço do gerente de projetos em proporcionar a comunicação efetiva entre todos os envolvidos.

\subsection{SUCESSO EM PROJETOS}

Sucesso em projetos pode ser entendido como o cumprimento de metas e objetivos pré-estabelecidos. Porém, definir o sucesso do projeto representa outro desafio para entender a gestão de projetos (OFORI, 2013). De acordo com Kerzner (2016), o sucesso de um projeto era medido verificando-se o cumprimento do prazo e orçamento definidos. Mas esse autor aponta uma mudança de percepção das partes interessadas, pois estas consideram que, para obter sucesso, é necessário que o projeto também agregue valor para os negócios da empresa e para os clientes.

Para Carvalho e Rabechini (2015), o sucesso em projetos depende de vários pontos de vista, como a perspectiva da parte interessada, o tipo de projeto, a perspectiva temporal (duração do projeto) e a unidade de análise (projeto e organização). No ambiente de projetos, existe um relativo consenso no que se refere ao sucesso em projetos como, por exemplo, cumprimento do escopo, tempo e custo, conhecida como a tripla restrição. Porém, muito se discute se essas medidas traduzem todas as dimensões do sucesso (CARVALHO; RABECHINI, 2015; KERZNER, 2016).

Nesse contexto, muitos autores analisam os motivos que conduzem os projetos ao sucesso, a fim de identificar os condicionantes de sucesso, também chamados de fatores críticos de sucesso (FCS) (DVIR; LIPOVETSKY; TISHLER, 
1998). Fortune e White (2006) realizaram um estudo a partir da análise de 63 (sessenta e três) publicações sobre fatores críticos de sucesso para o gerenciamento de projetos. Para eles, $81 \%$ das publicações avaliadas citam ao menos um dos três fatores a seguir, como mais frequentes: apoio da alta administração; objetivos realistas e claros; e planejamento claro e atualizado.

De acordo com Carvalho e Rabechini (2015) as listas de FCSs são extensas e envolvem diferentes aspectos. Fortune e White (2006) destacam suporte da alta gerência, clareza nos objetivos, planejamento adequado, comunicação eficiente e bom feedback, participação de clientes e usuários, gestão de mudanças adequada, entre outros. De acordo com Kerzner (2016) os FCSs mais comuns para as empresas são cumprimento do prazo, cumprimento do orçamento, cumprimento do processo de controle de mudanças, cumprimento da qualidade acordada, oportunidade de assinatura de contrato e viabilização de aditivos de contrato. Carvalho e Rabechini (2015) acrescentam boas práticas de gestão de projetos, estrutura adequada e competências apropriadas como fatores importantes para obtenção do sucesso em projetos.

Para Hwang e Lim (2013) a identificação dos FCSs auxilia a gerência do projeto a reduzir o índice de fracasso dos projetos; a identificar os projetos mais favoráveis para a empresa; e a identificar os pontos que necessitam de maior atenção no projeto, a fim de proceder com as ações corretivas necessárias. Jordão et al. (2015) ressaltam que esses três pontos são fundamentais para a busca da excelência na gestão de projetos, sendo ainda essenciais para manter a competitividade das empresas em uma economia globalizada.

No entanto, há muitos projetos que fracassam. Em 2011, o PMl efetuou uma pesquisa com as organizações participantes do benchmarking em gestão de projetos Brasil sobre os problemas que ocorrem com maior frequência e impactam o sucesso de seus projetos. Os respondentes apontaram 18 (dezoito) problemas distintos, conforme apresentado na Tabela 3.

Importante observar que, de acordo com a Tabela, problemas de comunicação $(40,1 \%)$ e riscos não avaliados corretamente $(22,9 \%)$, citados pelas organizações, ocupam o terceiro e oitavo lugar, respectivamente. Logo, é notório 
que a falta de comunicação é a mola propulsora para a instauração de riscos, que não foram devidamente interpretados e percebidos como possível fator de insucesso.

Tabela 3 - Problemas que ocorrem com maior frequência nos projetos

\begin{tabular}{lc}
\hline \multicolumn{1}{c}{ Item } & $\begin{array}{c}\text { Organizações que } \\
\text { citaram o item }\end{array}$ \\
\hline Não cumprimento dos prazos & $60,2 \%$ \\
\hline Mudanças de escopo constantes & $43,0 \%$ \\
\hline Problemas de comunicação & $40,1 \%$ \\
\hline Escopo não definido adequadamente & $39,5 \%$ \\
\hline Não cumprimento do orçamento & $28,3 \%$ \\
\hline Recursos humanos insuficientes & $28,3 \%$ \\
\hline Concorrência entre o dia a dia e o projeto na utilização de recursos & $27,6 \%$ \\
\hline Riscos não avaliados corretamente & $22,9 \%$ \\
\hline Mudanças de prioridades constantes ou falta de prioridade & $19,8 \%$ \\
\hline Problemas com fornecedores & $17,7 \%$ \\
\hline Estimativas incorretas ou sem fundamento & $15,6 \%$ \\
\hline Retrabalho em função de falta de qualidade do produto & $11,7 \%$ \\
\hline Falta de definição de responsabilidades & $10,2 \%$ \\
\hline Falta de uma metodologia de apoio & $7,5 \%$ \\
\hline Falta de apoio da alta administração / sponsor (patrocinador) & $7,3 \%$ \\
\hline Falta de competência para gerenciar projetos & $6,9 \%$ \\
\hline Falta de uma ferramenta de apoio & $6,7 \%$ \\
\hline Falta de conhecimento técnico sobre a área de negócio da organização & $2,1 \%$ \\
\hline
\end{tabular}

Fonte: PMl (2011)

Quatro anos após ter empreendido a pesquisa com as organizações participantes do benchmarking, especificamente no ano de 2015, o PMI realizou um estudo, em âmbito mundial. Tal estudo apontou que, em média, 36\% dos projetos são considerados insucessos. Sobre a questão "insucesso", Ofori (2013) destaca que, em geral, os projetos fracassam como resultado de um planejamento inadequado, mudanças constantes no escopo e, consequentemente, no prazo e orçamento, bem como na falta de monitoramento e de controle dos processos de gestão. Ter conhecimento desses tipos de estudo é imprescindível para melhoria do grau de sucesso dos projetos, visto que, ao atentar para o que conduz ao malogro e, devido a esse olhar, não reproduzi-lo, é uma grande possibilidade de obter êxito. 


\subsection{CONSIDERAÇÕES FINAIS DA REVISÃO BIBLIOGRÁFICA}

O estudo da literatura permite identificar conceitos importantes que serão utilizados na análise dos estudos de caso. A partir dos capítulos abordados nesta revisão da literatura, cabe destacar alguns pontos:

- o processo de internacionalização de empresas envolve uma análise minuciosa sobre o novo mercado de atuação. Trata-se de uma análise estratégica dos critérios internos, que motivam esse movimento de ampliação no mercado, e critérios externos, ou seja, aqueles relacionados ao novo mercado em que se deseja atuar;

- a ampliação das atividades da empresa para um novo país implica em riscos positivos ou negativos. Cabe à empresa identificar esses riscos e promover ações de controle, para aproveitar ou mitigar tais riscos;

- as boas práticas de gestão do processo de projetos (design) melhoram a qualidade dos projetos para execução e, consequentemente, reduzem o tempo e o custo gastos com retrabalhos, permitindo a consulta técnica para solução de problemas em tempo;

- a gestão da informação e do conhecimento aumentam a qualidade e o nível de detalhes pertinentes em todas as etapas de cada um dos processos de gestão. No que se refere a projetos, o nível de detalhes da informação exime a equipe de dúvidas para execução. Já a consulta de um banco de dados, existente na empresa, permite aproveitar o conhecimento adquirido em projetos semelhantes, a fim de melhorar o desempenho do projeto atual;

- a gestão da comunicação possibilita identificar os agentes envolvidos direta e indiretamente na execução do projeto e promover uma abordagem para comunicação com esses agentes, conforme perfil de cada um. Assim, reuniões para alinhamento das informações, comunicação por meio de documentos, entre outros, se fazem necessárias para evitar ou mitigar conflitos entre as partes; e

- o sucesso em projetos sempre esteve relacionado a cumprimento do escopo, prazo e custo previstos. Porém, vários autores apontam a necessidade de aliar 
esses três itens a boas práticas de gestão e satisfação dos clientes e demais partes interessadas.

A gestão é uma prática muito difundida para execução de projetos (project e design), mas não se restringe apenas a essas situações. O processo de internacionalização de uma empresa requer um movimento planejado que envolve identificação, análise e controle de diversos requisitos da gestão de projetos, como custos, partes interessadas, riscos e comunicação. Nos estudos de caso apresentados no capítulo seguinte será possível uma visão prática desses conceitos. 


\section{MÉTODOS DE PESQUISA}

Neste capítulo, serão apresentadas informações sobre as empresas e os casos estudados, com base nas entrevistas com gerentes, referentes aos processos de gestão adotados por cada empresa, sob a ótica dos projetos. Assim, serão explicitadas a caracterização das empresas e dos projetos e os processos de gestão adotados.

Cabe ressaltar que a pesquisa foi realizada em duas etapas. A primeira corresponde a uma revisão bibliográfica de conceitos relevantes para este estudo. A segunda, a uma avaliação, por meio de estudos de caso, visando identificar como as ferramentas e os processos de gestão, utilizados em projetos de infraestrutura estudados, influenciam nos resultados desses projetos.

\subsection{PESQUISA TEÓRICA}

A pesquisa bibliográfica está relacionada a conceitos como internacionalização; gestão de riscos; gestão do processo de projeto (design); gestão da informação e do conhecimento; gestão da comunicação; e sucesso em projetos. A pesquisa desses conceitos foi realizada por meio de consulta a banco de dados de teses e dissertações, livros e artigos, publicados em periódicos e congressos, de autores nacionais e internacionais.

Os artigos internacionais foram pesquisados nas bases de dados web of science e scopus, por intermédio das palavras chave project management, e internaciol*, no dia 03/05/2018. Na base web of science, a busca foi refinada para article e review, para tipos de documentos, e engineering civil e construction building technology, para categorias. Na base scopus, a investigação voltou-se para article, article in press e review, para tipos de documentos, e engineering, para área temática.

No total, essa pesquisa retornou 1.704 artigos. Todavia, foi realizada uma análise para verificação de repetições, de título e de resumo. Na primeira averiguação, foram retirados 34 artigos e na segunda, 1.555. O motivo deveu-se ao fato dos 
1589 artigos não terem relação específica com o tema estudado. A amostra final do estudo, portanto, possui 115 artigos.

Os pouco mais de 100 artigos escolhidos para a amostra evidenciam questões pertinentes ao propósito desta pesquisa. Importante ressaltar que a evolução das pesquisas que relacionam os conceitos de gestão de projetos e internacionalização de empresas de construção civil, tornaram-se mais significativas nos anos de 2004 a 2008. Anterior a esse interstício, pesquisas acerca dessa temática eram mínimas. Após, sofreram grandes oscilações, conforme se pode constatar pela figura 3 .

Figura 3 - Número de artigos publicados por ano

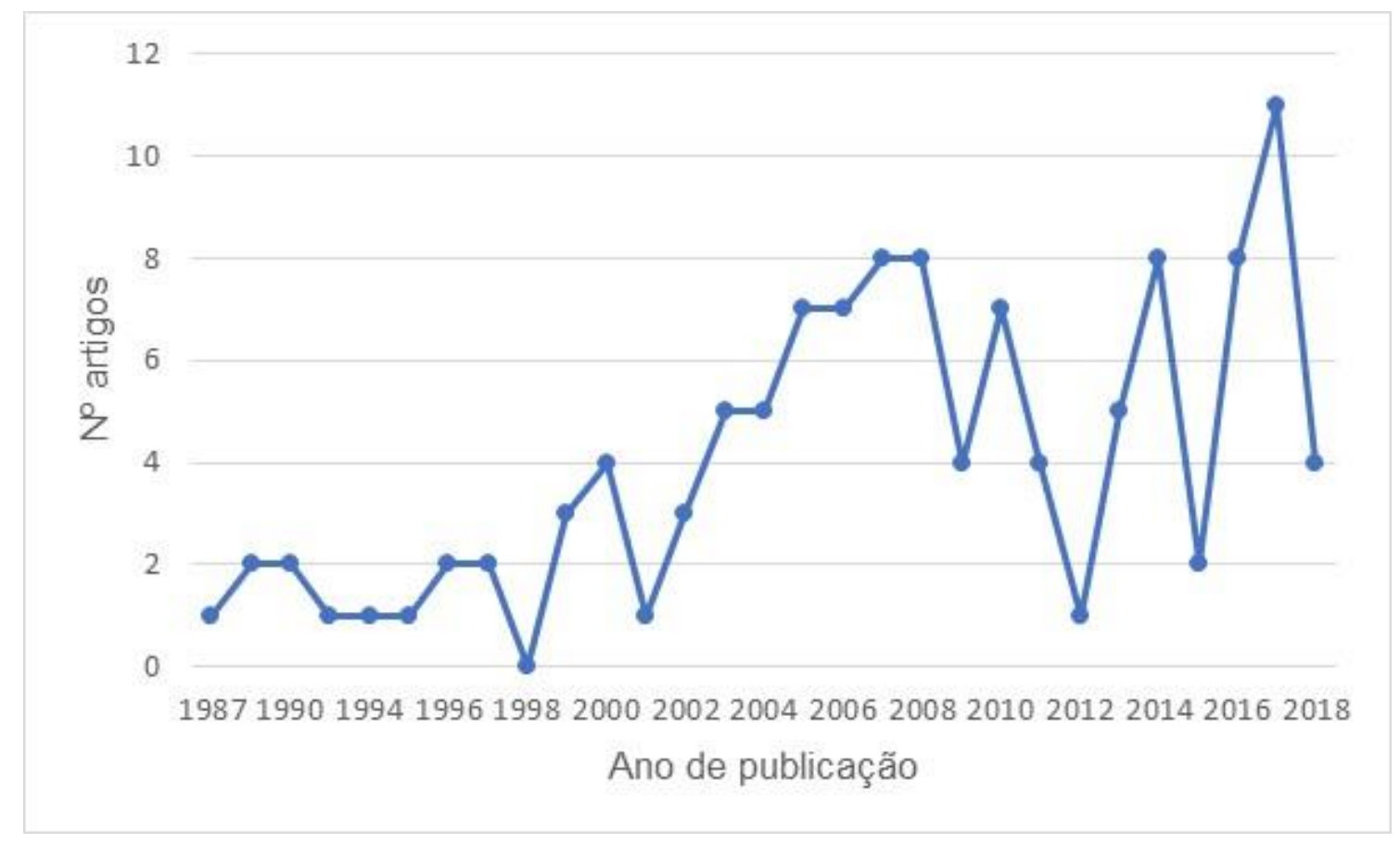

Fonte: dados da pesquisa nas bases web of science e scopus

Os quatro periódicos que mais publicaram artigos sobre internacionalização e gestão de projetos representam $44 \%$ da amostra total, aqui realizada. O primeiro deles, com 26 artigos, é o Journal of Construction Engineering and Management, que aborda assuntos como os fatores que afetam a construção internacional, os excessos de custo em construção internacional e fatores de riscos em projetos interacionais. O segundo, com 11 artigos, é Journal of Management in 
Engineering, que versa sobre assuntos como os fatores de riscos em projetos interacionais, competitividade e gestão de projetos. O terceiro e quarto periódicos, com 7 artigos cada, são Construction Management e Economics e Journal of Professional Issues in Engineering Educationand Practice. Ambos desenvolvem assuntos variados sobre o tema escolhido para este trabalho.

Os 115 artigos mais relevantes, selecionados para desenvolvimento do tema desta pesquisa, foram classificados tomando como parâmetro o Índice de Impacto do Artigo (AIF), que resulta do produto da citação média anual e do índice de impacto do periódico (JCRIF), de acordo com a fórmula (1), a seguir (HOMRICH et al, 2018; CARVALHO et al, 2013):

$$
\mathbf{A}_{\mathrm{IF}}=\text { Citação média anual } *\left(\mathrm{JCR}_{\mathrm{IF}}+1\right)
$$

Após a realização de cálculos, com os índices da amostra, 20 artigos foram identificados como outliers - dados que se diferenciam drasticamente de todos os outros, pontos fora da curva. Os outliers foram submetidos à análise de conteúdo e contribuíram com a revisão da literatura deste trabalho, pois juntos representaram um percentual de, aproximadamente, $60 \%$ do impacto total da amostra, como pode ser comprovado pela Tabela 4 .

Com a pesquisa de artigos nas bases de dados também foi possível avaliar e encontrar as palavras que melhor descrevessem a temática desejada para este estudo. Os resultados foram relevantes e precisos, tanto que as palavras-chave utilizadas nos artigos da amostra, foram os seguintes: international, project, management, construction. Estas aparecem em destaque na Figura 4.

Importante ressaltar que, além das palavras-chave apresentadas neste documento, também foram identificadas as palavras risk, performance, Knowedge, factores, costs, culture, entre outras. Isso é fundamental, pois auxilia, em muito, para uma análise, ainda mais consistente, sobre a tendência de pesquisas na área. 
Tabela 4 - Artigos mais relevantes

\begin{tabular}{|c|c|c|c|c|c|}
\hline Autores & Título & Periódico & $\begin{array}{l}\text { Média de } \\
\text { citações }\end{array}$ & JCR & AIF \\
\hline Jung J.Y., Wang Y.J. & $\begin{array}{l}\text { Relationship between total quality management } \\
\text { (TQM) and continuous improvement of } \\
\text { international project management (CIIPM) }\end{array}$ & Technovation & 5,33 & 4,80 & 30,94 \\
\hline Hastak M., Shaked A. & $\begin{array}{l}\text { ICRAM-1: Model for International Construction Risk } \\
\text { Assessment }\end{array}$ & $\begin{array}{l}\text { Journal of Management } \\
\text { in Engineering } \\
\text { Journal of Construction }\end{array}$ & 7,56 & 2,01 & 22,75 \\
\hline Gunhan S., Arditi D. & Factors affecting international construction & $\begin{array}{l}\text { Engineering and } \\
\text { Management }\end{array}$ & 7,69 & 1,74 & 21,04 \\
\hline $\begin{array}{l}\text { Lamancusa J.S., Zayas } \\
\text { J.L., Soyster A.L., Morell } \\
\text { L., Jorgensen J. }\end{array}$ & $\begin{array}{l}\text { The learning factory: Industry-partnered active } \\
\text { learning }\end{array}$ & $\begin{array}{l}\text { Journal of Engineering } \\
\text { Education }\end{array}$ & 6,90 & 1,98 & 20,53 \\
\hline $\begin{array}{l}\text { Kivrak S., Arslan G., } \\
\text { Dikmen I., Birgonul M.T. }\end{array}$ & $\begin{array}{l}\text { Capturing knowledge in construction projects: } \\
\text { Knowledge platform for contractors }\end{array}$ & $\begin{array}{l}\text { Journal of Management } \\
\text { in Engineering } \\
\text { Journal of Construction }\end{array}$ & 6,20 & 2,01 & 18,67 \\
\hline Rosenfeld Y. & Root-cause analysis of construction-cost overruns & $\begin{array}{l}\text { Engineering and } \\
\text { Management }\end{array}$ & 6,75 & 1,74 & 18,46 \\
\hline $\begin{array}{l}\text { Zhao Z.Y., Shen L.Y., Zuo } \\
\text { J. }\end{array}$ & $\begin{array}{l}\text { Performance and strategy of chinese contractors in } \\
\text { the international market }\end{array}$ & $\begin{array}{l}\text { Journal of Construction } \\
\text { Engineering and } \\
\text { Management }\end{array}$ & 6,33 & 1,74 & 17,32 \\
\hline Chan E.H.W., Tse R.Y.C. & $\begin{array}{l}\text { Cultural Considerations in International } \\
\text { Construction Contracts }\end{array}$ & $\begin{array}{l}\text { Journal of Construction } \\
\text { Engineering and } \\
\text { Management }\end{array}$ & 5,93 & 1,74 & 16,23 \\
\hline $\begin{array}{l}\text { Ke Y., Wang S., Chan } \\
\text { A.P.C. }\end{array}$ & $\begin{array}{l}\text { Risk allocation in public-private partnership } \\
\text { infrastructure projects: Comparative study }\end{array}$ & $\begin{array}{l}\text { Journal of Infrastructure } \\
\text { Systems }\end{array}$ & 6,88 & 1,36 & 16,20 \\
\hline $\begin{array}{l}\text { Javernick-Will A.N., } \\
\text { Scott W.R. }\end{array}$ & $\begin{array}{l}\text { Who needs to know what? Institutional knowledge } \\
\text { and global projects }\end{array}$ & $\begin{array}{l}\text { Journal of Construction } \\
\text { Engineering and } \\
\text { Management }\end{array}$ & 5,88 & 1,74 & 16,07 \\
\hline $\begin{array}{l}\text { Deng X., Low S.P., Li Q., } \\
\text { Zhao X. }\end{array}$ & $\begin{array}{l}\text { Developing competitive advantages in political risk } \\
\text { management for international construction } \\
\text { enterprises }\end{array}$ & $\begin{array}{l}\text { Journal of Construction } \\
\text { Engineering and } \\
\text { Management }\end{array}$ & 5,75 & 1,74 & 15,73 \\
\hline $\begin{array}{l}\text { Yildiz A.E., Dikmen I., } \\
\text { Birgonul M.T., Ercoskun } \\
\text { K., Alten S. }\end{array}$ & $\begin{array}{l}\text { A knowledge-based risk mapping tool for cost } \\
\text { estimation of international construction projects }\end{array}$ & $\begin{array}{l}\text { Automation in } \\
\text { Construction }\end{array}$ & 4,00 & 2,92 & 15,68 \\
\hline $\begin{array}{l}\text { Ozorhon B., Arditi D., } \\
\text { Dikmen I., Birgonul M.T. }\end{array}$ & $\begin{array}{l}\text { Performance of international joint ventures in } \\
\text { construction }\end{array}$ & $\begin{array}{l}\text { Journal of Management } \\
\text { in Engineering }\end{array}$ & 4,75 & 2,01 & 14,30 \\
\hline $\begin{array}{l}\text { Han S.H., Diekmann J.E., } \\
\text { Ock J.H. }\end{array}$ & $\begin{array}{l}\text { Contractor's risk attitudes in the selection of } \\
\text { international construction projects }\end{array}$ & $\begin{array}{l}\text { Journal of Construction } \\
\text { Engineering and } \\
\text { Management }\end{array}$ & 4,77 & 1,74 & 13,04 \\
\hline $\begin{array}{l}\text { Fidan G., Dikmen I., } \\
\text { Tanyer A.M., Birgonul } \\
\text { M.T. }\end{array}$ & $\begin{array}{l}\text { Ontology for relating risk and vulnerability to cost } \\
\text { overrun in international projects }\end{array}$ & $\begin{array}{l}\text { Journal of Computing in } \\
\text { Civil Engineering }\end{array}$ & 4,57 & 1,80 & 12,79 \\
\hline $\begin{array}{l}\text { Ozorhon B., Arditi D., } \\
\text { Dikmen I., Birgonul M.T. }\end{array}$ & $\begin{array}{l}\text { Implications of culture in the performance of } \\
\text { international construction joint ventures }\end{array}$ & $\begin{array}{l}\text { Journal of Construction } \\
\text { Engineering and } \\
\text { Management }\end{array}$ & 4,60 & 1,74 & 12,58 \\
\hline Kumaraswamy M.M. & $\begin{array}{l}\text { Contractor Evaluation and Selection: A Hong Kong } \\
\text { Perspective }\end{array}$ & $\begin{array}{l}\text { Building and } \\
\text { Environment }\end{array}$ & 2,32 & 4,05 & 11,71 \\
\hline $\begin{array}{l}\text { Han S.H., Kim D.Y., Kim } \\
\text { H. }\end{array}$ & $\begin{array}{l}\text { Predicting profit performance for selecting } \\
\text { candidate international construction projects }\end{array}$ & $\begin{array}{l}\text { Journal of Construction } \\
\text { Engineering and } \\
\text { Management }\end{array}$ & 4,27 & 1,74 & 11,69 \\
\hline Pheng L.S., Hongbin J. & $\begin{array}{l}\text { Internationalization of Chinese construction } \\
\text { enterprises }\end{array}$ & $\begin{array}{l}\text { Journal of Construction } \\
\text { Engineering and } \\
\text { Management }\end{array}$ & 4,13 & 1,74 & 11,30 \\
\hline $\begin{array}{l}\text { Han S.H., Park S.H., Kim } \\
\text { D.Y., Kim H., Kang Y.W. }\end{array}$ & $\begin{array}{l}\text { Causes of bad profit in overseas construction } \\
\text { projects }\end{array}$ & $\begin{array}{l}\text { Journal of Construction } \\
\text { Engineering and } \\
\text { Management }\end{array}$ & 3,73 & 1,74 & 10,19 \\
\hline
\end{tabular}

Fonte: dados da pesquisa nas bases web of science e scopus 
Figura 4 - Mapa de palavras-chaves

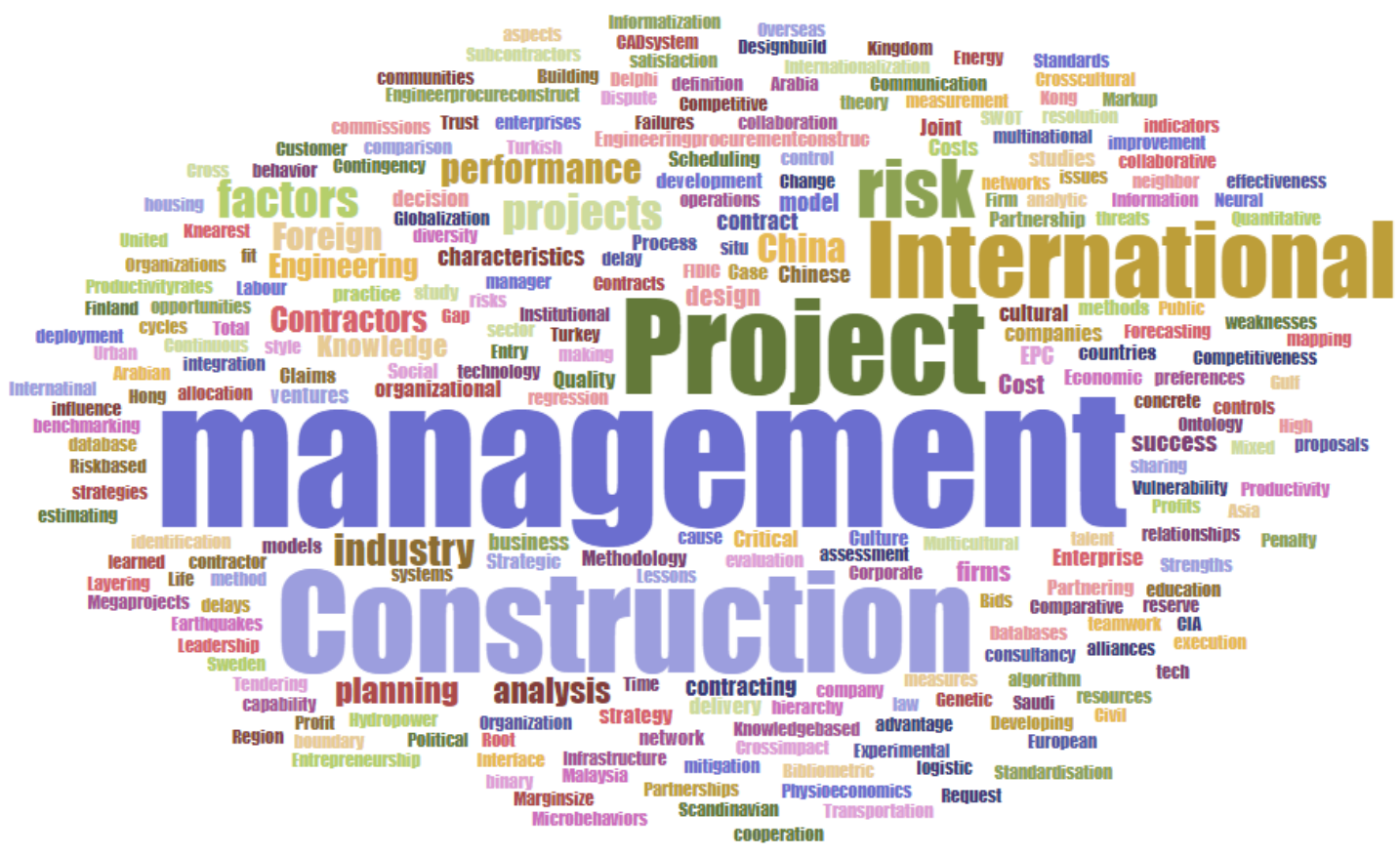

Fonte: dados da pesquisa nas bases web of science e scopus

\subsection{ESTUDOS DE CASO}

Nesta etapa do trabalho foi utilizado o método de estudo de casos múltiplos, envolvendo quatro empresas de construção civil e seis projetos de infraestrutura. Segundo Yin (2001, p. 32), estudo de caso "é uma forma de se fazer pesquisa empírica que investiga fenômenos contemporâneos dentro do seu contexto de vida real, em situações em que as fronteiras entre o fenômeno e o contexto não estão claramente estabelecidas, onde se utiliza múltiplas fontes de evidência". Assim, a principal tendência nos estudos de casos é tentar entender por que uma decisão ou várias decisões foram tomadas, como foram implementadas e quais os resultados alcançados (YIN, 2001).

A pesquisa seguiu um roteiro de perguntas semiestruturadas e, de acordo com Yin (2015, p. 77), para a aplicação dos diagnósticos (levantamento de dados), foram trabalhados alguns aspectos no pesquisador, tais como:

- formular um bom questionário e interpretar as respostas de forma razoável; 
- ser bom ouvinte e não se prender- a ideologias ou preconceitos;

- permanecer adaptável às novas situações, que podem ser positivas para a pesquisa;

- ter noção clara dos assuntos em estudo; e

- ser imparcial e sensível a evidências contrárias, conduzindo a pesquisa de forma ética.

A condução dos casos seguiu a proposição de Yin (2015) para estudo de casos múltiplos, uma vez que, com isso, as comparações realizadas auxiliarão no esclarecimento dos resultados obtidos, além de possibilitar uma ampla exploração do tema e uma elaboração teórica ainda mais consistente. A Figura 5 evidencia de forma bastante objetiva como se processa a condução de estudo de caso.

Figura 5 - Condução dos estudos de caso

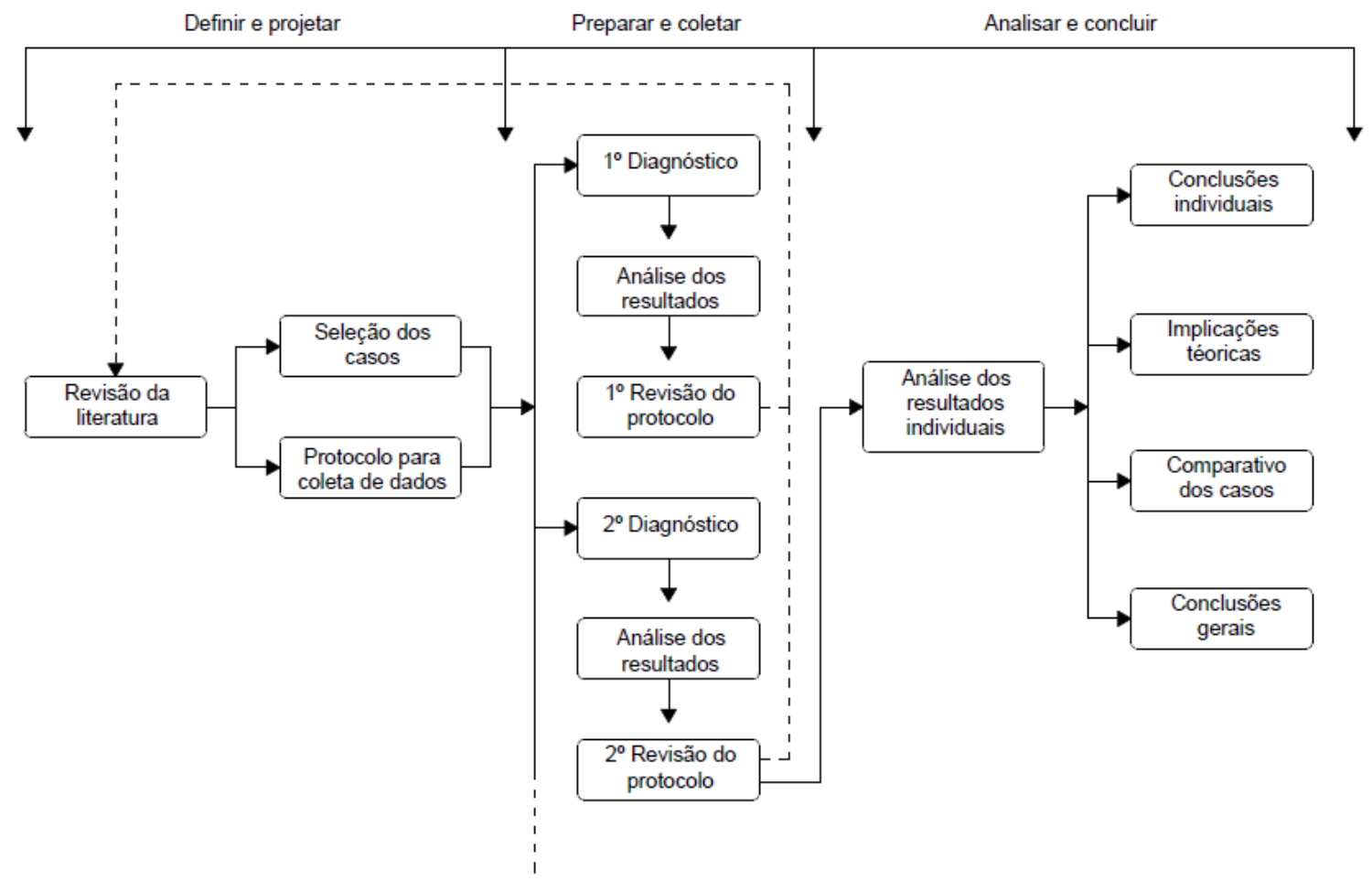

Fonte: Adaptado de Yin (2015)

A fim de conduzir devidamente o estudo de casos múltiplos, a Literatura foi mapeada de acordo com os critérios apresentados no item 3.1, deste trabalho, 
além da análise de outros documentos de pesquisa como artigos, dissertações e teses.

Na sequência, ocorreu a seleção dos casos, seguindo os seguintes critérios: empresas de construção civil de grande porte, atuantes especificamente no setor de infraestruturas, e com projetos semelhantes na condição de execução e cliente (contratante do projeto); possuir estrutura organizacional e processos bem definidos; facilidade no acesso à dados e informações; e profissionais disponíveis. Nesta etapa foram selecionadas duas empresas internacionais, uma de origem espanhola e outra de origem argentina, e duas empresas brasileiras Quadro 8).

\section{Quadro 8 - Caracterização dos estudos de caso}

\begin{tabular}{|c|c|c|c|}
\hline Empresa & Caracterização & Caso & Caracterização \\
\hline \multirow{2}{*}{ Empresa A } & \multirow{2}{*}{$\begin{array}{l}\text { Trata-se de uma multinacional espanhola } \\
\text { presente em diversos segmentos do } \\
\text { mercado. Possui uma filial em São Paulo } \\
\text { desde } 1996 \text { e atua no segmento de } \\
\text { infraestruturas no Brsasil desde } 2009 .\end{array}$} & Caso A1 & $\begin{array}{l}\text { Construção de um terminal para atracação } \\
\text { de navios, como parte das obras de um } \\
\text { importante porto localizado no norte } \\
\text { fluminense. }\end{array}$ \\
\hline & & Caso A2 & $\begin{array}{l}\text { Obra rodoviária, compreendendo atividades } \\
\text { de terraplenagem, obras de arte especiais e } \\
\text { correntes, pavimentação, além de um túnel e } \\
\text { outros serviços. }\end{array}$ \\
\hline Empresa B & $\begin{array}{c}\text { Trata-se de um conglomerado ítalo- } \\
\text { argentino, fundado como uma empresa } \\
\text { internacional em 1945. Em } 1947 \text { a empresa } \\
\text { inaugurou sua filial no Brasil, com atuação na } \\
\text { construção civil }\end{array}$ & Caso B1 & $\begin{array}{l}\text { Engenharia, projeto e construção de um cais } \\
\text { para atracação de navios, localizado na } \\
\text { região sul do país. }\end{array}$ \\
\hline \multirow{2}{*}{ Empresa C } & \multirow{2}{*}{$\begin{array}{l}\text { Trata-se de uma empresa nacional fundada } \\
\text { em } 1947 \text {, atuando inicialmente, no segmento } \\
\text { de infraestruturas com obras de } \\
\text { pavimentação e saneamento, obras } \\
\text { marítimas, construção imobiliária e } \\
\text { concessões rodoviárias e de saneamento. }\end{array}$} & Caso C1 & $\begin{array}{l}\text { Construção de um terminal para atracação } \\
\text { de navios, como parte das obras de um } \\
\text { importante porto localizado no norte } \\
\text { fluminense. }\end{array}$ \\
\hline & & Caso C2 & $\begin{array}{l}\text { Elaboração de projeto executivo e execução } \\
\text { de serviços de construção e montagem do } \\
\text { píer de um terminal de regaseificação. }\end{array}$ \\
\hline Empresa D & $\begin{array}{c}\text { Trata-se de um grupo global, de origem } \\
\text { brasileira, criado em } 1923 \text { atuando, } \\
\text { incialmente, no segmento de construção } \\
\text { imobiliária. Em } 1945 \text { o grupo ampliou as } \\
\text { atividades para construção de infraestrutura } \\
\text { e, em 1984, expandiu os negócios para } \\
\text { outros países. }\end{array}$ & Caso D1 & $\begin{array}{l}\text { Construção uma ponte que faz parte da } \\
\text { concretização de uma grande leva de } \\
\text { investimentos recentes na remodelação } \\
\text { viária nos bairros Morumbi e Chácara Santo } \\
\text { Antônio, na zona Sul da cidade de São } \\
\text { Paulo. }\end{array}$ \\
\hline
\end{tabular}

Fonte: dados da pesquisa 
Os critérios de seleção dos respondentes foram os seguintes: participação em mais de um projeto como gerente ou coordenador de projetos; e conhecimento de gestão de projetos.

A coleta de dados ocorreu tendo em vista as seguintes ações:

1) aplicação do questionário (APÊNDICE A), que contou com a participação de seis gerentes e dois coordenadores de projetos. Esses profissionais possuem 10 anos ou mais de experiência na gerência de projetos de grande porte. Isso proporcionou uma perspectiva sobre o assunto, a partir da visão geral desses profissionais sobre o projeto em que atuam e sobre a organização em que estão inseridos, além das impressões observadas pelo autor no ambiente organizacional pesquisado;

2) observação dos processos desenvolvidos nos projetos das empresas, por meio de visitas ao local de atuação dos profissionais entrevistados e de outros profissionais envolvidos com os processos de gestão analisados;

3) análise dos documentos utilizados nos projetos da empresa, focando aqueles utilizados nos processos de gestão analisados; e

4) conversas com membros das equipes dos projetos, a fim de identificar pontos em comum ou pontos divergentes entre os estudos de casos, e que impactam na condução dos processos de gestão analisados. 


\section{APRESENTAÇÃO E ANÁLISE DOS RESULTADOS}

Este tópico busca apresentar as empresas e os projetos estudados, bem como analisar os dados obtidos acerca das relações entre os processos de gestão adotados em empresas de construção civil brasileiras e em empresas de construção civil estrangeiras que atuam no Brasil. Complementarmente, buscase compreender o impacto da gestão de projetos para o sucesso destes projetos. A análise dessas relações é de carácter qualitativo.

\subsection{Empresa A}

\subsubsection{Caracterização da empresa}

Trata-se de uma multinacional espanhola que atua em diversos segmentos do mercado. Possui filial em São Paulo, desde 1996. A sede é em Madri, desde 1931. Destaca-se pela atuação em vários países e segmentos da engenharia, tais como infraestruturas, energias, águas, indústrias, concessões, entre outros. Além disso, é muito ativa na produção de energia sustentável, sendo ganhadora de prêmios. O último foi em 2015, após construção de um parque eólico no caribe, México. A empresa passou por vários processos de incorporações de outras empresas hispânicas até chegar na forma vigente, em 1997. No Brasil, opera no segmento de infraestruturas, desde 2009, e possui, aproximadamente, 3 mil funcionários contratados.

A crise global instalada em 2008 afetou, de forma significativa, o grupo espanhol. Isso motivou a ampliação dos negócios para os países da América latina, a partir de 2009. Nesse contexto, o Brasil é um dos países prioritários para crescimento da empresa, dentro da estratégia de internacionalização. Além de investir no desenvolvimento de projetos de infraestrutura para clientes públicos e privados, ampliou suas atividades no mercado brasileiro de gestão de água, transportes, logística e energia. A empresa possui uma estrutura organizada por segmentos de atuação, como pode ser observado pelo organograma organizacional evidenciado na Figura 6. 
Figura 6 - Organograma da empresa A

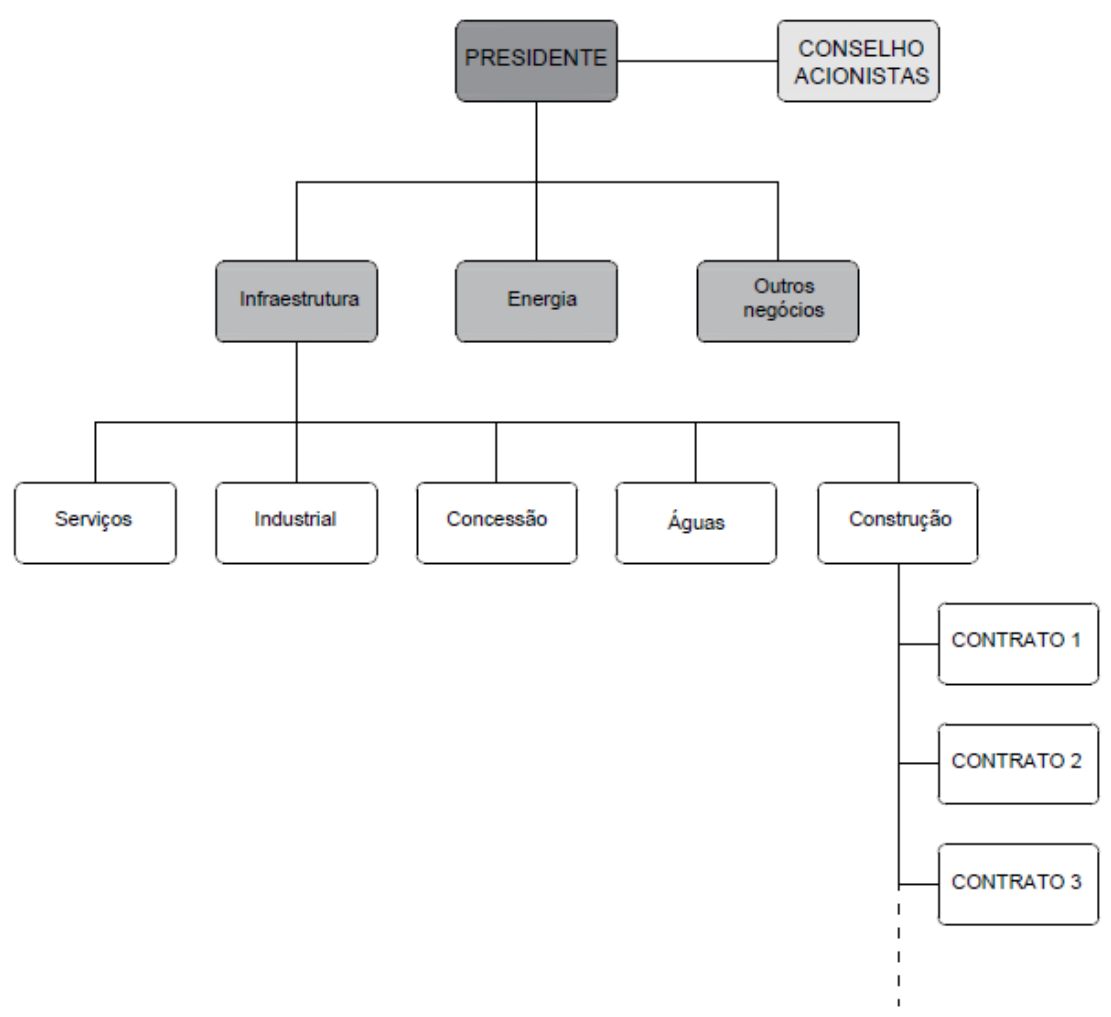

Fonte: dados da empresa

Mediante os vários pontos ligados ao segmento de construção de infraestruturas, conforme se pode observar no organograma acima, a empresa, para dar vazão a todas as demandas existentes, adota as seguintes estratégias para os projetos que serão iniciados ou que estão em andamento: (1) atendimento ao cliente, uma vez que há interesse em se fixar no mercado e ampliar a concorrência com as grandes construtoras brasileiras; (2) levantamento e análise qualitativa dos riscos; (3) extensa mobilização de recursos (mão de obra, equipamentos, materiais e serviços), para iniciar a execução das obras; (4) elaboração de cronograma inicial e atualizações, quando necessário; (5) análise técnica dos projetos básicos e projetos executivos, para propor mudanças nos métodos construtivos, a fim de reduzir o prazo de execução; (6) subcontratação de grande parte dos serviços de execução do empreendimento, incluindo mão de obra; (7) elaboração de pleitos para reivindicação de valores mobilizados e não utilizados em função de mudanças de escopo ou paralisados em função de atrasos no inícios das atividades. 


\subsubsection{Caracterização dos casos A1 e A2}

O primeiro estudo de caso da empresa $A$, que será denominado $A 1$, é um projeto considerado destaque da empresa no Brasil. Trata-se da construção de um terminal para atracação de navios, como parte das obras de um importante porto localizado no norte fluminense. O escopo de tal projeto compreende engenharia, design e construção de diques externos em um complexo portuário. Para alcançar os objetivos do projeto, a empresa investiu em inovação dos métodos construtivos, trazendo para o Brasil um equipamento muito específico, desenvolvido pela empresa, para execução de obras semelhantes.

O segundo estudo de caso da empresa A, considerado como A2, está relacionado a um empreendimento rodoviário dividido em dois projetos semelhantes, somando uma extensão de $21.131 \mathrm{Km}$ e compreendendo atividades de terraplenagem, obras de arte especiais e correntes, pavimentação, além de um túnel e outros serviços de acabamento. Os projetos possuem características urbanas, devido à alta intensidade de tráfego nas redondezas, elevada densidade populacional e habitacional na região, sendo necessária a remoção de comunidades, remoções de interferências e reposições de serviços. Os projetos também estão dentro de áreas ambientalmente protegidas, com forte atuação de órgãos voltados para esse tipo de controle. Outro ponto relevante é que os projetos possuem interface direta com duas importantes rodovias, que serão interrompidas para execução de uma parte do escopo.

Os casos estudados utilizam uma estrutura organizacional funcional e compartilham parte da equipe de apoio com outros projetos da empresa que apresentam semelhança no tipo de contrato e proximidade entre os canteiros de obra. Observe-se o organograma do projeto A1, referendado na Figura 7.

As equipes compartilhadas, em consonância com a disposição apresentada no organograma, são chamadas de Staff e se reportam à diretoria do projeto, atendendo às necessidades dos gerentes dos projetos. 
Figura 7 - Organograma dos projetos da empresa A

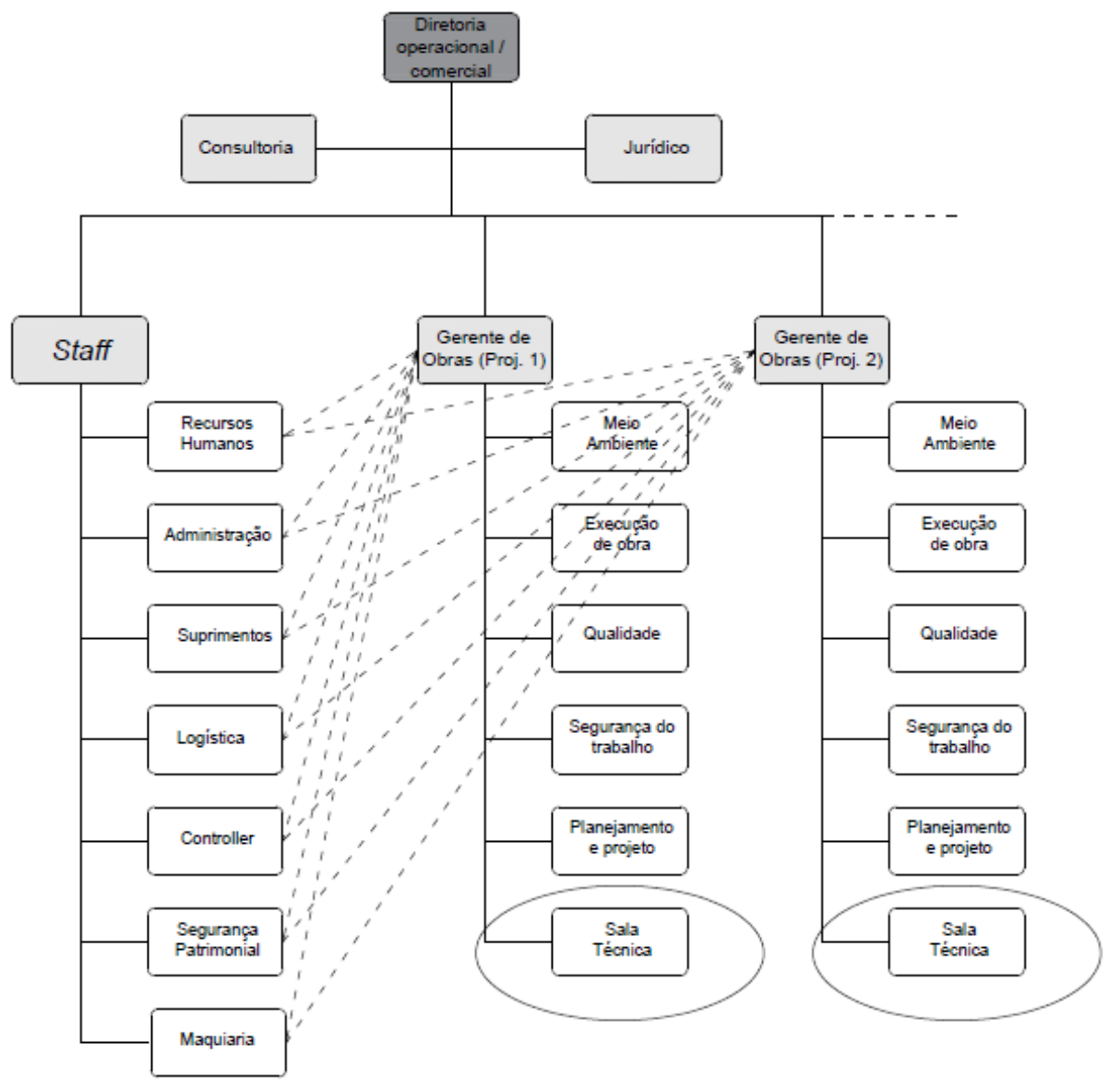

Fonte: dados da empresa

Os projetos possuem equipes distintas, lideradas por um gerente de obras, que por sua vez é liderado por um diretor de departamento ou diretor de obra. Os principais agentes envolvidos na execução dos projetos são:

- cliente (contratante) - composto por uma equipe multidisciplinar que fiscaliza as atividades desenvolvidas nos projetos da empresa $A$. No estudo A1 o cliente é privado e no estudo A2 o cliente é público;

- diretoria - composta por um diretor operacional e um diretor comercial. O primeiro é responsável por assessorar a equipe de obra, no que se refere a questões técnicas, operacionais, financeiras, contratações de consultorias etc. Já o segundo é responsável por atuar comercialmente junto ao cliente, buscando captar novos projetos. Também auxilia a equipe de obra na manutenção de uma boa imagem para o cliente; 
- gerente de obras - possui autonomia sobre as equipes, podendo demitir e contratar sempre que julgar necessário, subcontratar recursos, consultorias e demais itens essenciais à execução do projeto. Porém, em alguns casos, é imprescindível consultar os diretores;

- equipes de apoio compartilhadas (Staff):

$>$ recursos humanos - responsável pelos processos de contratação/demissão, benefícios etc.;

$>$ administração - responsável pelo controle de documentação, controle de custos, almoxarifado, questões fiscal e contábil, contas a pagar, faturamento direto, serviços gerais, tecnologia da informação (TI), entre outros;

$>$ suprimentos - responsável pelas compras de materiais e contratação de maquinários e serviços;

> logística - responsável pelo transporte de funcionários, transporte de malotes etc.;

> controller - responsável pela administração contratual da obra (pleitos e reivindicações junto aos clientes);

$>$ segurança patrimonial - responsável pela segurança dos recursos do projeto, guarda do canteiro etc.; e

$>$ maquinaria - responsável pela distribuição de máquinas nas frentes de serviço e manutenção desses equipamentos.

- equipes de apoio e execução específicas de cada projeto:

$>$ meio ambiente - responsável pelas questões ambientais do projeto;

> execução da obra -formada por engenheiros que exercem cargos de coordenadores de produção, além de mestres, encarregados, topografia e demais funcionários, responsáveis por executar o escopo contratado;

> segurança - responsável pela segurança do trabalho;

> qualidade - responsável pela garantia de qualidade dos materiais e peças executadas da obra, controle da empresa subcontrata, controle de ensaios de laboratório e liberação de peças para execução; 
$>$ planejamento e projeto - responsável pelo planejamento da obra e recebimento e controle de projetos (design); e

> topografia - responsável pelas medições topográficas.

Para o estudo A2 foi inserida uma equipe chamada "sala técnica" que é responsável pelo planejamento, medição do cliente, topografia e projetos (design), conforme destacado na figura 7. A sala técnica é uma equipe de apoio à obra e se reporta ao gerente de contrato.

Nos projetos da empresa, as equipes são distintas e muito densas, em torno de 10 a 15 funcionários por equipe, variando de cargos de coordenação a cargos técnicos. Essa composição de equipes deveria contribuir para a agilidade na execução das atividades. No entanto, as equipes atuam, em grande parte, de forma independente, atendendo seus coordenadores, que por sua vez, atendem ordens diretas dos gerentes de departamento e dos diretores de obras. Como consequência, não há sinergia entre as equipes do projeto, sendo que as atividades dependentes umas das outras são afetadas e isso afeta o bom andamento do projeto.

\subsubsection{Gestão de riscos}

A empresa A efetua uma análise qualitativa dos riscos dos projetos, separada em oportunidades, ou seja, eventos positivos que, se ocorrerem, podem beneficiar o resultado do projeto (Quadro 9) e riscos, que, ao contrário do item anterior, são eventos negativos quem, se ocorrerem podem reduzir o resultado do projeto (Quadro 10). Essa análise, apesar de bem detalhada, não estima valores para o contingenciamento de custos, sendo que esses valores são computados apenas na ocorrência dos riscos.

Um ponto importante no processo de gestão dos riscos, conforme descrito por Kululanga e Kuotcha (2010), é a análise contínua dos riscos identificados, conforme descrito e já visto no Quadro 4. 
Quadro 9 - Matriz de oportunidades dos projetos da empresa A

\begin{tabular}{|c|c|c|c|c|c|}
\hline Causas & Evento & Probab. & Efeitos & Conseq. & Impacto \\
\hline \multirow{2}{*}{$\begin{array}{l}\text { Compartilhar meios auxiliares } \\
\text { com outras obras no Brasil. } \\
\text { Compartilhar ajuda entre as } \\
\text { obras. }\end{array}$} & \multirow{2}{*}{$\begin{array}{l}\text { Minimizar o uso de } \\
\text { máquinas e } \\
\text { equipamentos } \\
\text { auxiliares }\end{array}$} & \multirow{2}{*}{ Moderada } & $\begin{array}{l}\text { Redução do investimento } \\
\text { inicial }\end{array}$ & Leve & Moderado \\
\hline & & & Redução de custos indiretos & Moderada & Moderado \\
\hline \multirow{3}{*}{$\begin{array}{l}\text { Aprovação pelo Cliente de } \\
\text { modificações no layout em } \\
\text { plano e em elevação. }\end{array}$} & \multirow{3}{*}{$\begin{array}{l}\text { Otimização da } \\
\text { compensação de } \\
\text { terras }\end{array}$} & \multirow{3}{*}{ Moderada } & $\begin{array}{l}\text { Redução do volume de } \\
\text { material a ser transportado } \\
\text { para aterro sanitário }\end{array}$ & Moderada & Moderado \\
\hline & & & $\begin{array}{l}\text { Redução do volume de } \\
\text { escavação }\end{array}$ & Moderada & Moderado \\
\hline & & & $\begin{array}{l}\text { Redução do volume de } \\
\text { material de empréstimo }\end{array}$ & Moderada & Moderado \\
\hline \multirow{2}{*}{$\begin{array}{l}\text { Aprovação da execução de } \\
\text { inclinações mais verticais } \\
\text { Aprovação da eliminação de } \\
\text { bermas em clareiras }\end{array}$} & \multirow{2}{*}{$\begin{array}{l}\text { Otimização do } \\
\text { projeto }\end{array}$} & \multirow{2}{*}{ Moderada } & $\begin{array}{l}\text { Redução do volume de } \\
\text { escavação }\end{array}$ & Moderada & Moderado \\
\hline & & & $\begin{array}{l}\text { Redução do volume de } \\
\text { material para aterro sanitário }\end{array}$ & Leve & Moderado \\
\hline \multirow{2}{*}{$\begin{array}{l}\text { Cumprimento dos prazos de } \\
\text { execução. } \\
\text { Boa gestão dos } \\
\text { subcontratados. } \\
\text { Boa imagem ambiental } \\
\text { Boa imagem social durante a } \\
\text { execução das obras. }\end{array}$} & \multirow{2}{*}{$\begin{array}{l}\text { Boa execução dos } \\
\text { trabalhos }\end{array}$} & \multirow{2}{*}{ Moderada } & $\begin{array}{l}\text { Exceder as expectativas do } \\
\text { Cliente }\end{array}$ & Grave & Significativo \\
\hline & & & $\begin{array}{l}\text { Boa imagem social para a } \\
\text { empresa }\end{array}$ & Moderada & Moderado \\
\hline \multirow{2}{*}{$\begin{array}{l}\text { Execução completa das } \\
\text { estruturas com treliças }\end{array}$} & \multirow{2}{*}{$\begin{array}{l}\text { Otimização do } \\
\text { processo de } \\
\text { construção de } \\
\text { estruturas }\end{array}$} & \multirow{2}{*}{ Improvável } & $\begin{array}{l}\text { Redução de gastos com } \\
\text { meios auxiliares }\end{array}$ & Moderada & Moderado \\
\hline & & & $\begin{array}{l}\text { Redução do tempo de } \\
\text { execuçãodas obras de arte }\end{array}$ & Moderada & Moderado \\
\hline $\begin{array}{l}\text { Mudança nos parâmetros } \\
\text { geotécnicos do projeto } \\
\text { através de estudos } \\
\text { geotécnicos adicionais. } \\
\end{array}$ & $\begin{array}{l}\text { Otimização do } \\
\text { projeto }\end{array}$ & Improvável & $\begin{array}{l}\text { Redução do custo global do } \\
\text { capítulo das fundações }\end{array}$ & Leve & Baixo \\
\hline
\end{tabular}

Fonte: dados da empresa

Apesar das matrizes de oportunidades (Quadro 7) e de riscos (Quadro 8) dos projetos da empresa serem extensas, esta restringe a análise dos riscos e oportunidades somente à fase de identificação, para fins de planejamento inicial dos projetos. As demais fases do processo, como planejamento de respostas aos riscos e monitoramento e controle, não fazem parte da rotina dos projetos.

As planilhas de riscos e oportunidades são compartilhadas com os diretores, gerente do projeto e equipe de administração contratual, e não são divulgadas para os demais gerentes e coordenadores de áreas. Como consequência, boa parte dos envolvidos, desconhecendo as oportunidades, deixa de potencializar os resultados e se limita a executar o projeto. Já os riscos, quando ocorrem, são tratados de forma isolada, e os custos incorridos nessas tratativas não são registrados, ou seja, são aceitos e incorporados aos custos. 
Quadro 10 - Matriz de riscos dos projetos da empresa A

\begin{tabular}{|c|c|c|c|c|c|}
\hline Causas & Evento & Probab. & Efeitos & Conseq. & Impacto \\
\hline \multirow{2}{*}{$\begin{array}{l}\text { Moradores se recusam a sair } \\
\text { das casas desapropriadas }\end{array}$} & \multirow{2}{*}{$\begin{array}{l}\text { Parar o trabalho de } \\
\text { demolição devido às } \\
\text { demandas dos } \\
\text { proprietários } \\
\text { expropriados }\end{array}$} & \multirow{2}{*}{ Provável } & $\begin{array}{l}\text { Paralisação do trabalho de } \\
\text { demolição }\end{array}$ & Moderado & Significativo \\
\hline & & & $\begin{array}{l}\text { Atraso na conclusão do } \\
\text { trabalho de demolição }\end{array}$ & Moderado & Significativo \\
\hline \multirow{4}{*}{$\begin{array}{l}\text { Mão de obra disponível não } \\
\text { possui qualificações } \\
\text { suficientes. }\end{array}$} & \multirow{4}{*}{$\begin{array}{l}\text { Falta de disponibilidade } \\
\text { de mão-de-obra na área }\end{array}$} & \multirow{4}{*}{ Provável } & $\begin{array}{l}\text { Atraso na contratação de } \\
\text { mão-de-obra local }\end{array}$ & Moderado & Significativo \\
\hline & & & $\begin{array}{l}\text { Custos de treinamento } \\
\text { superiores aos esperados }\end{array}$ & Leve & Moderado \\
\hline & & & $\begin{array}{l}\text { Salários superiores aos } \\
\text { esperados }\end{array}$ & Moderado & Significativo \\
\hline & & & $\begin{array}{l}\text { Reclamações salariais por } \\
\text { funcionários contratados }\end{array}$ & Moderado & Significativo \\
\hline $\begin{array}{l}\text { Erros de execução por } \\
\text { pessoal técnico. } \\
\text { A implementação da planta } \\
\text { pré-fabricada não é } \\
\text { apropriada. } \\
\text { Falta de insumos (cimento, } \\
\text { agregados, aço). }\end{array}$ & $\begin{array}{l}\text { A produção da fábrica } \\
\text { de vigas pré-fabricadas } \\
\text { é menor do que o } \\
\text { esperado }\end{array}$ & Improvável & $\begin{array}{l}\text { Atraso na execução do } \\
\text { serviço }\end{array}$ & Moderado & Moderado \\
\hline \multirow{2}{*}{$\begin{array}{l}\text { O Cliente desaprova as } \\
\text { mudanças levantadas pelo } \\
\text { Contratado. } \\
\text { O Cliente leva muito tempo } \\
\text { para aprovar as alterações } \\
\text { de projeto propostas pelo } \\
\text { contratado }\end{array}$} & \multirow{2}{*}{$\begin{array}{l}\text { Não é possível } \\
\text { implementar as } \\
\text { alterações ao projeto } \\
\text { apresentadas pelo } \\
\text { Contratado }\end{array}$} & \multirow{2}{*}{ Provável } & Atraso geral do projeto & Moderado & Significativo \\
\hline & & & $\begin{array}{l}\text { Custos mais elevados do que } \\
\text { o esperado }\end{array}$ & Grave & Alto \\
\hline \multirow{4}{*}{$\begin{array}{l}\text { Lentidão na seleção de } \\
\text { pessoas-chave } \\
\text { Atrasos na gestão de } \\
\text { licenças de trabalho } \\
\text { Atrasos na mobilização do } \\
\text { pessoal selecionado }\end{array}$} & \multirow{4}{*}{$\begin{array}{l}\text { Atraso na incorporação } \\
\text { no Projeto do pessoal } \\
\text { técnico e administrativo } \\
\text { expatriado necessário } \\
\text { para o início do trabalho } \\
\text { (Gerente de projeto, } \\
\text { Chefe de sala técnico, } \\
\text { etc.) }\end{array}$} & \multirow{4}{*}{ Provável } & Atrasos no início das obras & Moderado & Significativo \\
\hline & & & Imagem ruim diante do cliente & Leve & Moderado \\
\hline & & & $\begin{array}{l}\text { Ocupação de cargos por } \\
\text { parte do pessoal do parceiro }\end{array}$ & Moderado & Significativo \\
\hline & & & $\begin{array}{l}\text { Decisão errada no início da } \\
\text { obra }\end{array}$ & Moderado & Significativo \\
\hline $\begin{array}{l}\text { Ataraso por parte do cliente } \\
\text { na liberação de licenças } \\
\text { ambientais ne } \\
\text { desapropriações }\end{array}$ & $\begin{array}{l}\text { As licenças ambientais } \\
\text { e desapropriações } \\
\text { geridas pelo cliente não } \\
\text { atendem às expectativas } \\
\text { do contratado }\end{array}$ & Moderada & Atrasos no início dos serviços & Leve & Moderado \\
\hline \multirow{2}{*}{$\begin{array}{l}\text { O estudo geotécnico não é } \\
\text { confiável }\end{array}$} & \multirow{2}{*}{$\begin{array}{l}\text { As condições } \\
\text { geotécnicas da obra são } \\
\text { piores do que o } \\
\text { esperado }\end{array}$} & \multirow{2}{*}{ Improvável } & $\begin{array}{l}\text { Aumento na frequência das } \\
\text { mudanças de equipamentos }\end{array}$ & Moderado & Moderado \\
\hline & & & Menor rendimento & Moderado & Moderado \\
\hline \multirow{4}{*}{$\begin{array}{l}\text { Mudanças políticas na cidade } \\
\text { devido ao processo eleitoral }\end{array}$} & \multirow{4}{*}{$\begin{array}{l}\text { Mudanças políticas nos } \\
\text { municípios através das } \\
\text { quais o projeto } \\
\text { Rodoanel passa }\end{array}$} & \multirow{4}{*}{ Rara } & $\begin{array}{l}\text { Atrasos na obtenção de } \\
\text { licenças }\end{array}$ & Moderado & Baixo \\
\hline & & & $\begin{array}{l}\text { Paralisação dos processos } \\
\text { administrativos }\end{array}$ & Moderado & Baixo \\
\hline & & & Aumento de impostos & Grave & Moderado \\
\hline & & & Novos impostos & Grave & Moderado \\
\hline $\begin{array}{l}\text { A inflação é maior do que o } \\
\text { esperado. } \\
\text { Aumento de preço local para } \\
\text { a execução dos serviços }\end{array}$ & $\begin{array}{l}\text { Atraso na obtenção da } \\
\text { campanha geotécnica } \\
\text { de contraste }\end{array}$ & Moderada & $\begin{array}{l}\text { Impossibilidade de repassar } \\
\text { esse ajuste para o cliente }\end{array}$ & Moderado & Moderado \\
\hline
\end{tabular}

Fonte: dados da empresa

A condução do processo de gestão de riscos pela empresa caracteriza uma rotina de execução, em que não existe parâmetro para comparação dos custos reais incorridos com os valores inicialmente previstos. 
Nos casos estudados, diversos riscos previstos ocorreram de fato durante a execução do projeto. Isso ocasionou acréscimo considerável de custo e prazo contratual. Cabe destaque para o item "alteração de projeto", que constava tanto na planilha de oportunidades, quanto na planilha de riscos. Conforme será tratado no item seguinte, em função da gestão do processo de projeto ineficiente, a empresa não conseguiu implantar melhorias no projeto (design) e sofreu com atrasos da obra.

\subsubsection{Gestão do processo de projeto}

Para preparação da proposta de preços, a empresa contratada já possui acesso aos projetos básicos do empreendimento que será construído. Mas, na maioria dos casos, esses projetos possuem pouca informação e pouco detalhamento. Além disso, as alterações do projeto básico em relação ao projeto executivo são significativas, o que impacta no planejamento e custo definidos na proposta.

Nas obras de grande porte da empresa, como é o caso dos projetos $A 1$ e $A 2$, é feita uma reunião de kick-off-meeting (KOM) com o cliente. Nessa reunião, são apresentadas ao cliente, por meio dos diretores e gerente de obra, as informações referentes ao método construtivo que será adotado, a composição da equipe do projeto, além detratadas dúvidas técnicas.

Os projetos da empresa $A$ não possuem uma equipe dedicada à gestão do processo de projetos. Nos casos estudados a elaboração dos projetos é de responsabilidade dos clientes. Assim, os projetos são entregues para o gerente de obra, por meio de carta, e são distribuídos para a equipe de execução sem que ocorra análise crítica ou verificação de compatibilidade, a Figura 8 apresenta o fluxo do processo de projetos para os casos estudados.

A empresa possui um projetista, que atua como um consultor interno, para dar apoio às demais equipes do projeto no que se refere a dúvidas de projetos, elaboração de detalhamentos que não constam nos projetos, elaboração de desenhos auxiliares e participação de reuniões para contratação de prestadores de serviços específicos. 
Figura 8 - Fluxograma de projetos da empresa A

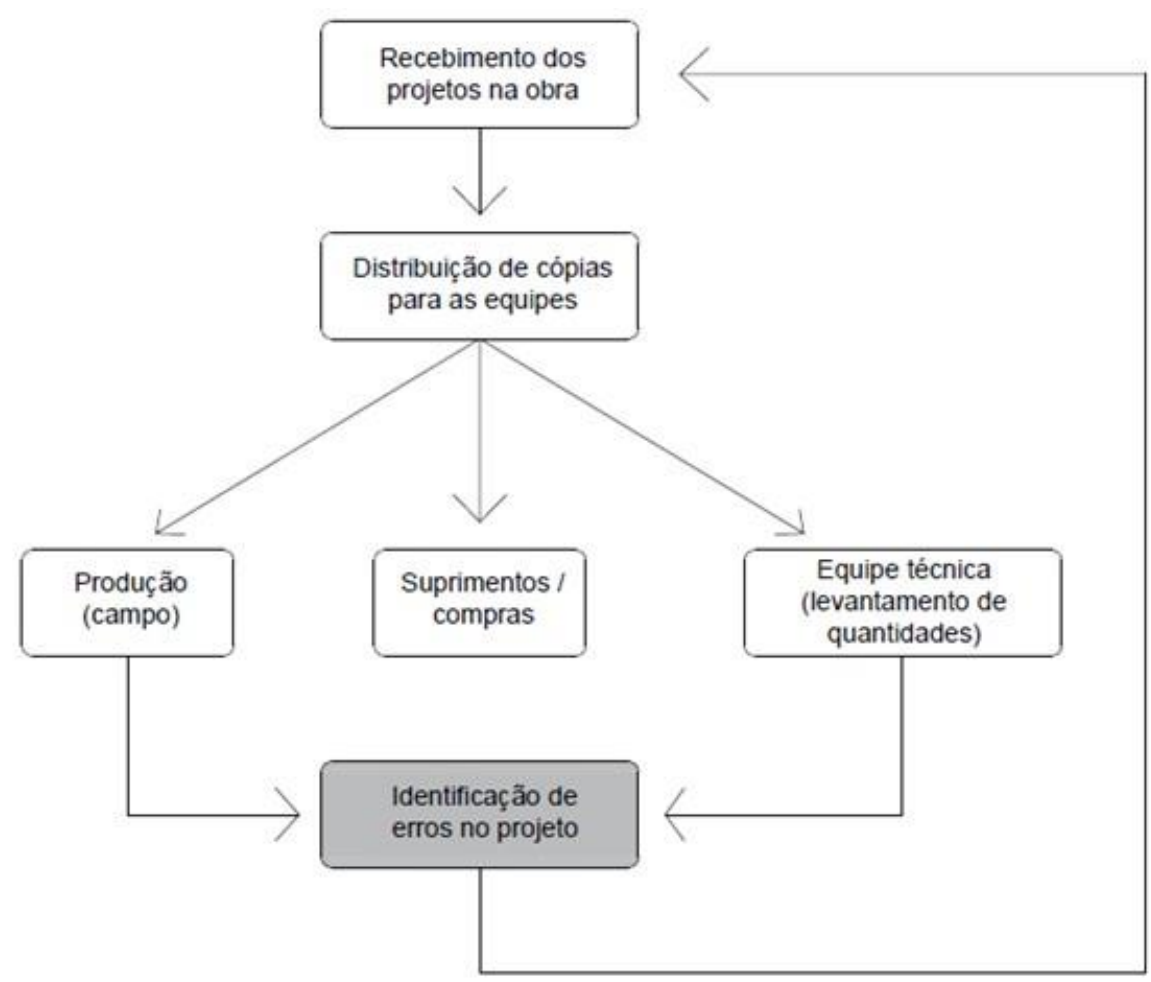

Fonte: dados da pesquisa

Além disso, o projetista faz análise e proposição de alteração técnica, objetivando redução do prazo e do custo de execução da obra. No entanto, essas propostas de alterações precisam de autorização dos projetistas na sede da empresa em Madri. Esse processo demanda certo tempo que, na maioria dos casos, não se dispõe para o prazo de execução do empreendimento. Como resultado, as melhorias de projeto não são atendidas, por dois motivos: ou a etapa de projeto é executada antes do retorno de Madri ou as propostas de mudança não são aprovadas pelo cliente. Cabe ressaltar que esse projetista atende vários projetos da empresa.

Outro ponto que requer atenção é relativo à falta de análise crítica e compatibilização de projetos antes da liberação para a equipe de produção. Essa carência ocasionou diversos problemas durante a execução dos serviços, como exemplo:

- incompatibilidade do projeto de fôrma com o projeto de armação em casos como esse, a empresa aciona o cliente, por meio de carta, 
e procede com os devidos reparos na armação ou solicita nova armação. O atraso e aumento de custos na execução da atividade são inevitáveis, conforme se pode perceber pelo detalhe do projeto de armação (Figura 9) e pela armação executada (Figura 10);

Figura 9 - Detalhe do projeto de armação

$x$ Não é possível exibir esta imagem no momento.

Fonte: dados do projeto

Figura 10 - Armação executada conforme projeto

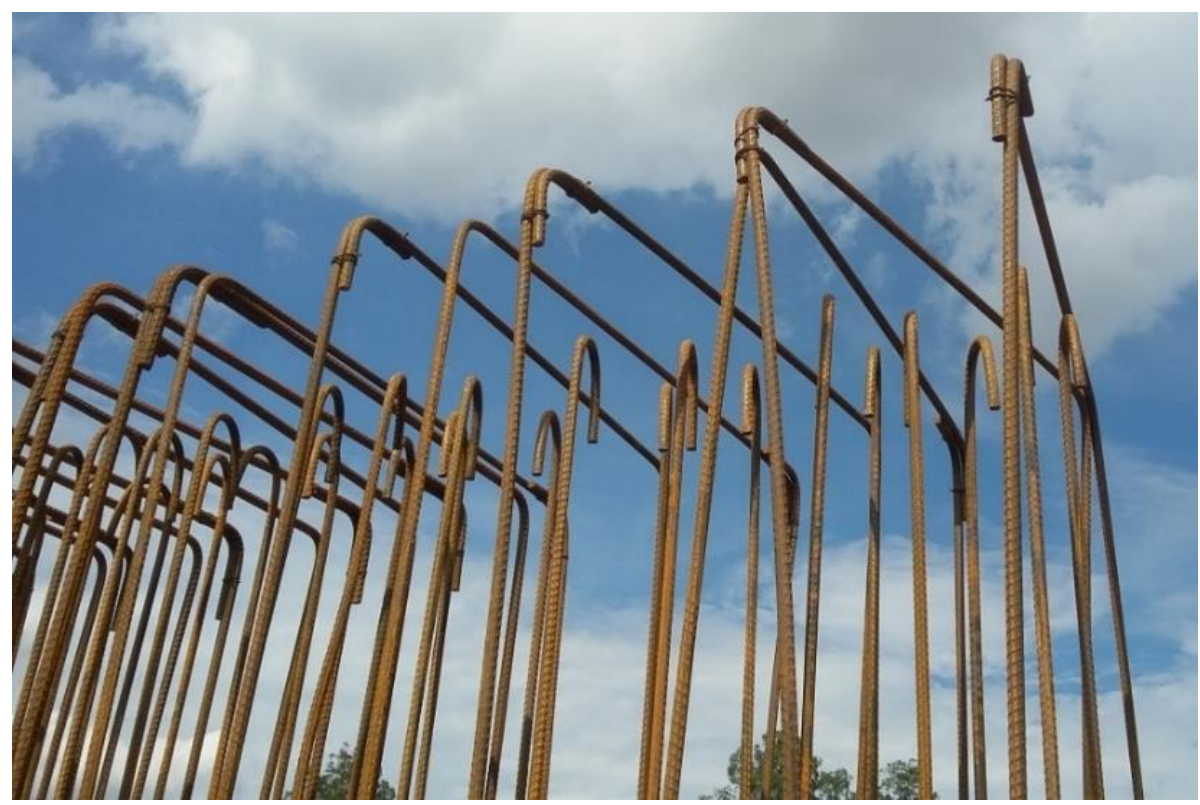

Fonte: dados do projeto 
- incompatibilidade do projeto de armação passiva e armação ativa nesse caso a armação passiva, muito densa, impossibilitou a passagem dos cabos para armação ativa. $A$ empresa acionou 0 cliente por meio de carta/consulta técnica e aguardou a solução, visto que se trata de uma questão estrutural;

- inconsistências em relação ao projeto de proteção dos limites da obra - em situação desse tipo, o cliente projetou estruturas de proteção incompatíveis com as localidades de aplicação. A empresa acionou o cliente por meio de carta/ consulta técnica e aguardou a solução do problema, que consistiu em visita à obra de uma equipe composta por membros da empresa contratante e da empresa contratada para análise dos locais e revisão dos métodos de proteção previsto no projeto;

- Falta de detalhamentos de peças para execução das obras, como por exemplo, projeto de fachada e projeto de estruturas dos postos de pedágio, conforme representado nas Figuras 11 e 12. Neste caso, a empresa acionou o cliente por meio de carta/ consulta técnica e aguardou a solução. Porém, houve atraso no pedido de materiais para execução da atividade, uma vez que o problema foi identificado no levantamento de quantidade para compra de materiais;

- inconsistência entre as revisões de projetos. Nesse caso, elementos que aparecem em um projeto, não constam em revisões atuais do mesmo. Porém, a necessidade de execução do referido elemento é reconhecida em outras plantas. Isso gera dúvida e atraso para a equipe de execução, uma vez que o procedimento para solução da pendência é semelhante aos tópicos anteriores, ou seja, a empresa acionou o cliente por meio de carta/ consulta técnica e aguardou a solução.

Os problemas relacionados a projetos são identificados no momento da execução e causam um impacto significativo na produtividade da equipe de campo. Por esse motivo, consequentemente, ocorre o aumento nos custos de execução em função de retrabalho e de equipes paradas aguardando a solução 
para a situação adversa. Além disso, o número de revisões dos projetos é elevado, pois cada problema de projeto identificado em obra segue para revisão, de maneira isolada.

Figura 11 - Detalhe do projeto de arquitetura da fachada

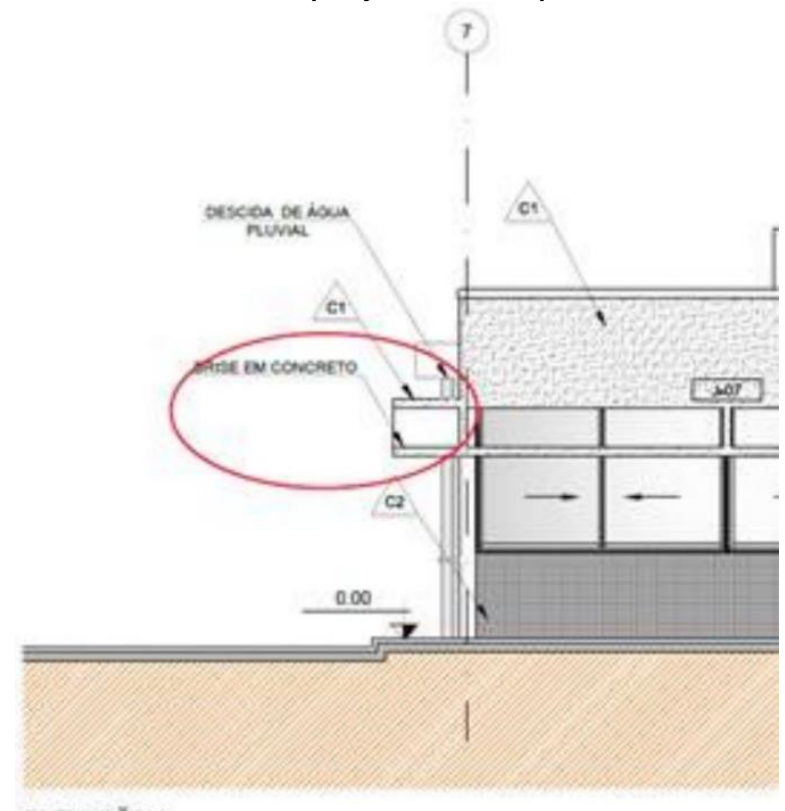

ELEvaÇÃo 3

Fonte: dados do projeto

Figura 12 - Detalhe do projeto de estruturas da fachada

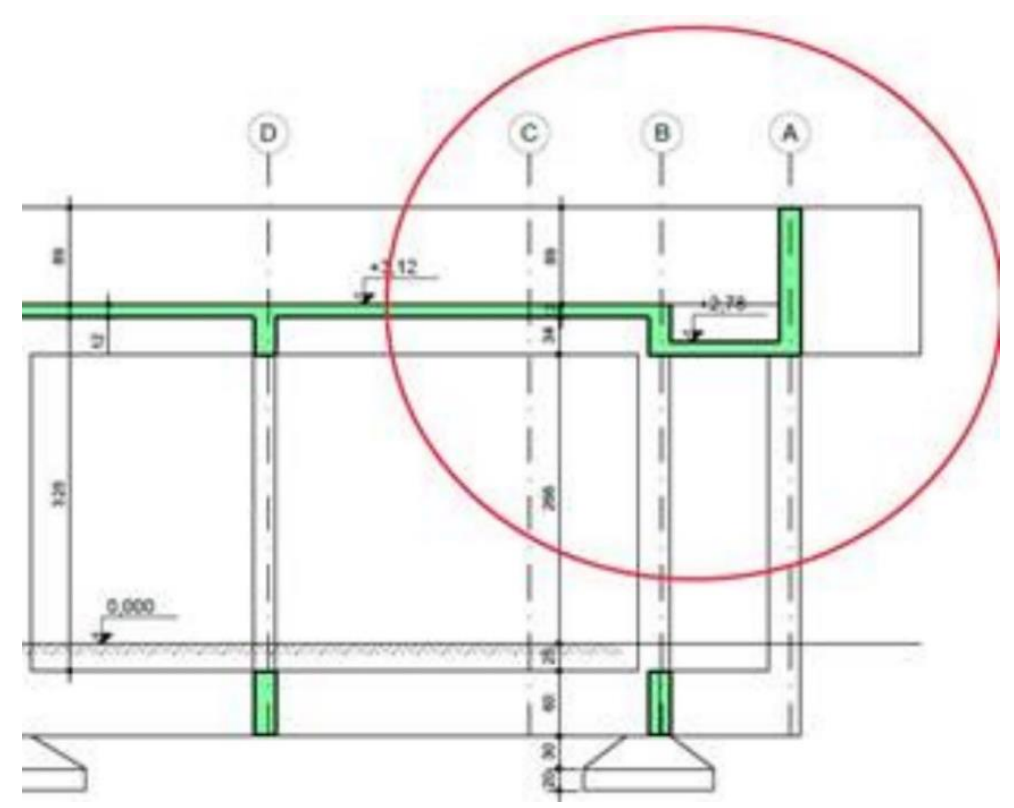

Fonte: dados do projeto 
Cabe destacar que a falta de uma equipe dedicada à gestão do processo de projetos nos casos A1 e A2 também contribuiu para o aumento de erros na distribuição dos projetos para execução. Isso ocorreu por dois motivos: ou a última revisão de projeto não era entregue para os engenheiros de campo ou os projetos obsoletos não eram recolhidos e descartados. Essa falha de procedimento implicou no uso de projetos desatualizados para execução. Nesse caso, erros dessa natureza são de responsabilidade da empresa.

\subsubsection{Gestão da informação e do conhecimento}

Nos casos estudados A1 e A2 a gestão da informação e do conhecimento está concentrada no setor de controller, responsável pela administração contratual. No entanto, esse setor se limita a tratar dados contratuais, ou seja, prazos e marcos do contrato da empresa A com o cliente, além de pleitos e reivindicações para o caso de descumprimento de alguma cláusula desse contrato. Para o caso específico da elaboração de reivindicações, a equipe de controller buscou modelos em projetos anteriores.

A empresa não possui um processo de gestão da informação bem definido para os projetos, uma vez que não existe um banco de dados formal para consulta das equipes envolvidas nesses projetos, ficando sob responsabilidade de cada coordenador ou gerente de área transmitir, de forma democrática, as informações necessárias para a condução do projeto. Esse fato corrobora a literatura que destaca o setor de construção como uma área difícil para se ter sucesso no registro das informações (ANBARl et al., 2008).

Da mesma forma, a empresa não possui um processo de gestão do conhecimento, pois o conhecimento adquirido pela empresa, por meio de seus membros, não é registrado formalmente, ou seja, não existe um banco de dados de lições aprendidas ou para compartilhamento de processos e procedimentos adotados nos projetos. Assim, o conhecimento fica concentrado nos gerentes e coordenadores e se perde quando um desses é desligado da empresa. 


\subsubsection{Gestão da comunicação}

Nos casos estudados da empresa $A$, não existe um processo formal para a gestão da comunicação interna. Dessa forma, cada equipe trabalha independentemente, atendendo as demandas de resultados semanais, quinzenais e/ou mensais, exigidos por seus gestores ou pela diretoria do contrato. Como consequência, algumas equipes produzem resultados duplicados, por exemplo: a equipe de produção faz a apropriação de custo dos serviços executados e o setor de custos produz o mesmo estudo; a equipe de sala técnica faz o levantamento de quantidades de projeto (design) e a equipe de suprimentos produz o mesmo resultado para contratação e aquisição de materiais; a equipe de controller faz o levantamento de itens passíveis de reivindicação, junto ao cliente e a equipe de sala técnica faz um levantamento semelhante para fins de medição, também junto ao cliente.

No entanto, os projetos estudados possibilitaram a promoção de reuniões semanais com as principais lideranças, para tratar pontos críticos considerados estratégicos para o projeto. $\mathrm{Na}$ maioria das vezes, os assuntos estavam relacionados à execução de uma etapa do projeto ou ao atendimento às solicitações do cliente. Essas informações eram repassadas para cada equipe por meio de reuniões setoriais. A rotina, porém, não garantiu que as informações fossem efetivamente transmitidas ou que ocorressem em tempo hábil, como exemplo, as equipes do projeto relataram atrasos na contratação de mão de obra, serviço e fornecimento de materiais.

Já a comunicação externa com o cliente, órgãos reguladores e subcontratados era formal, por cartas, e-mails, atas de reuniões, entre outros. Esses documentos foram geridos pelo setor de administração contratual. 


\subsection{Empresa B}

\subsubsection{Caracterização da empresa}

Trata-se de um conglomerado ítalo-argentino, fundado como empresa internacional em 1945. Inicialmente o grupo oferecia serviços de engenharia para clientes, na América Latina e na Europa. Em seguida, principiou as atividades de construção, sendo a primeira obra inaugurada em 1949. Atualmente a empresa possui uma equipe de profissionais e um faturamento de, aproximadamente, 51.200 funcionários e US\$ 19 bilhões por ano, respectivamente.

Em 1947 a empresa inaugurou sua filial no Brasil, com atuação na construção civil. Posteriormente, ampliou os serviços no país, em 1999, com produtos com tecnologia avançada, além de serviços de gestão de supply chain integrados em nível global para clientes, como as principais empresas de óleo e gás do mundo, e também para empresas industriais e de engenharia. Em 2012, começou a se destacar com produção de aço. A empresa já concluiu mais de 3.500 projetos, de acordo com as normas internacionais ISO/BS/OHSAS, na América, Europa, Meio Oriente e África.

$\mathrm{Na}$ construção civil, a empresa oferece serviços de engenharia, construção e fornecimento de equipamentos, além de operação e serviços de gestão de projetos de grande porte, em todo o mundo. A presença global permite que a empresa tenha profundo conhecimento dos padrões técnicos, leis e regulamentações, impostos, entidades financeiras, sindicatos e serviços terceirizados nas regiões onde ela opera. No segmento de infraestrutura a empresa atua em construção para terceiros e com investimentos em construções para ampliação dos próprios negócios.

Atualmente, a empresa oferece serviços nos segmentos de petróleo e gás, energia, plantas industriais, refinarias de petróleo e plantas petroquímicas, mineração, infraestrutura e serviços de infraestrutura, e arquitetura e engenharia civil, conforme apresentado no organograma da empresa (Figura 13). 


\subsubsection{Caracterização do caso B1}

O estudo de caso da empresa, que será denominado (B1), contempla engenharia, projeto e construção de um cais de 300 metros de comprimento, 8,5 metros de calado homologado e capacidade de carga de 10 a 45 toneladas $/ \mathrm{m}^{2}$, localizado na região sul do país. O projeto faz parte da adequação do canteiro existente na empresa, que já possui um cais, em operação, de 40,9 metros de comprimento e 5,9 metros de calado. O cais é considerado uma obra de importância estratégica para a empresa, pois representa uma oportunidade de ampliação dos negócios offshore.

A licitação desse projeto foi aberta para o mercado e obteve retorno de 5 construtoras e também do segmento de construção do próprio grupo, proprietário da empresa B. A melhor proposta foi a 6, ou seja, a da empresa B. Portanto, o contrato, para execução do projeto, foi firmado com essa seção da empresa que abriu a licitação. As propostas de execução do projeto das 05 construtoras, mais a da empresa B, constam na Tabela 5.

Foram analisados os métodos construtivos e o orçamento que cada uma das empresas apresentou e assim ficou definido que a execução da obra seria realizada pela própria empresa, com subcontratação de alguns serviços específicos. A decisão foi baseada na disponibilidade de equipe da empresa $B$, que possui experiência adquirida em projetos semelhantes, o que gerou maior segurança nos números orçados e na capacidade de execução, além do orçamento estimado em $25 \%$ abaixo das outras empresas licitantes. 
Figura 13 - Organograma da empresa B

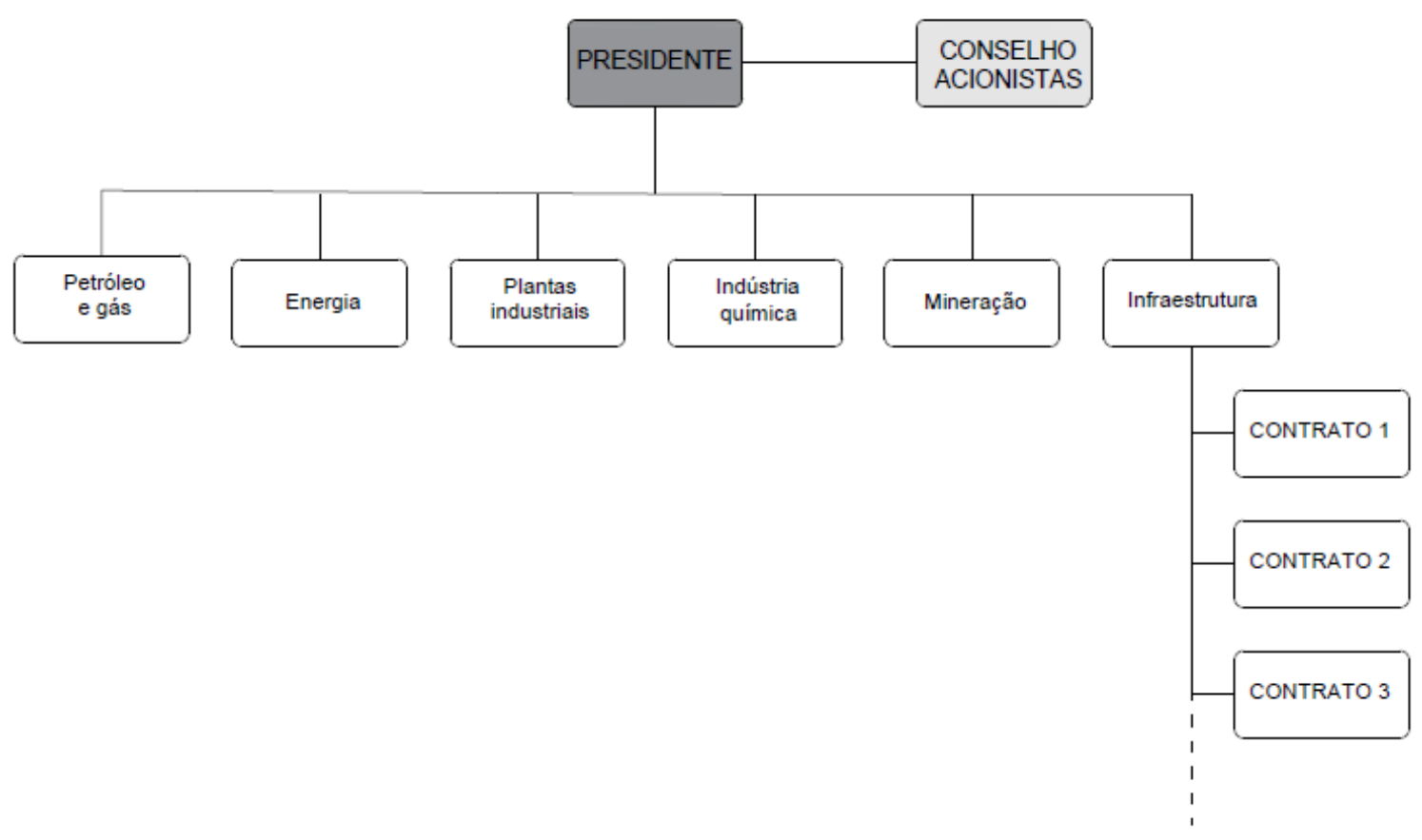

Fonte: dados da empresa

O caso de estudo também possui uma estrutura organizada por projetos, a qual é funcional. Algumas equipes são compartilhadas com mais de um projeto, como é o caso das equipes de recursos humanos e movimentação de cargas (Figura 14).

Tabela 5 - Propostas para execução do projeto B1

\begin{tabular}{|c|c|}
\hline $\begin{array}{c}\text { Empresas participantes } \\
\text { da licitação }\end{array}$ & Valor (R\$) \\
\hline Proposta 1 & 140 milhões \\
Proposta 2 & 115 milhões \\
Proposta 3 & 137 milhões \\
Proposta 4 & 184 milhões \\
Proposta 5 & 253 milhões \\
Proposta 6 (Empresa B) & 98 milhões \\
\hline
\end{tabular}

Fonte: dados da empresa 
Figura 14 - Organograma dos projetos da empresa B

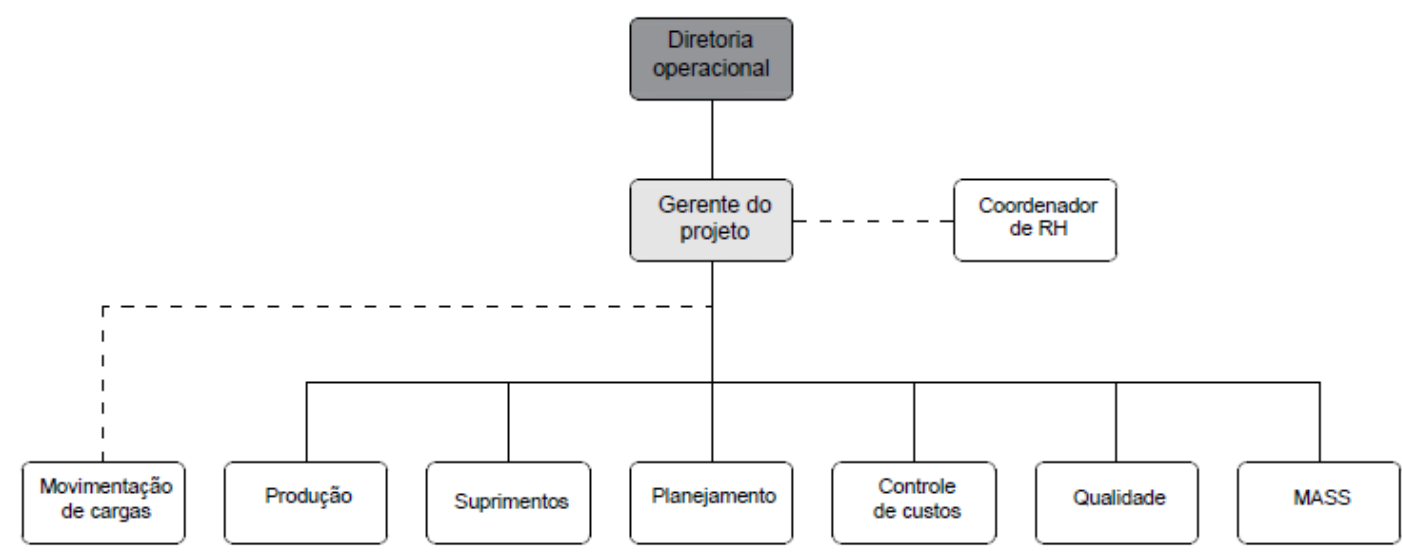

Fonte: dados da empresa

Os projetos da empresa possuem equipes lideradas por gerentes funcionais, que por sua vez são liderados por um gerente de projeto, responsável por fazer as mediações entre o cliente (contratante) e a diretoria da empresa (contratada). Os principais agentes envolvidos na execução do projeto são:

- cliente (contratante) - equipe multidisciplinar que avalia a execução dos projetos;

- diretoria operacional - responsável por assessorar a equipe de obra no que se refere a questões técnicas, operacionais, financeiras, contratações de consultorias etc.

- gerente do projeto - principal autoridade da obra. Tem total autonomia sobre as equipes, podendo demitir e contratar sempre que julgar necessário, subcontratar recursos, consultorias e demais itens imprescindíveis para a execução do projeto;

- equipes compartilhadas com outros projetos:

$>$ coordenadora de recursos humanos $(\mathrm{RH})$ - responsável pelos processos de contratação/demissão, treinamentos, benefícios etc.;

$>$ movimentação de carga - também responsável pela logística de movimentação das cargas horizontais e verticais da obra;

- equipes de apoio e execução exclusivas do projeto: 
$>$ produção - engenheiros que exercem cargos de coordenadores de produção, além de mestres, encarregados, topografia e demais funcionários, responsáveis por executar o escopo contratado;

$>$ suprimentos - responsável pelas compras de materiais e contratação de maquinários e serviços;

$>$ planejamento - responsável pelo planejamento da obra e administração das datas marcos contratuais;

$>$ controle de custos - responsável pelos controles dos valores dos insumos adquiridos e serviços contratados para execução da obra, além dos controles de perdas;

$>$ qualidade - responsável pela garantia de qualidade dos materiais e peças executadas da obra, controle da empresa subcontrata, controle de ensaios de laboratório e liberação de peças para execução;

$>$ MASS - equipe, responsável pela gestão de meio ambiente, saúde e segurança da obra.

\subsubsection{Gestão de riscos}

A empresa B possui uma equipe de profissionais específica para análise de riscos de novos projetos. Essa equipe utiliza técnicas de identificação dos riscos por meio de workshops de lições aprendidas. Participam desses workshops os diretores da empresa, o gerente do novo projeto e gerentes de outros projetos semelhantes. Como resultado do trabalho, são apontados riscos e oportunidades para a execução do projeto.

Também é feita uma análise qualitativa e quantitativa para os itens identificados, o que define a probabilidade de ocorrência para cada item e o impacto financeiro dessa ocorrência. $O$ valor identificado para os riscos são adicionados ao custo do projeto. Já os valores identificados para as oportunidades são incorporados aos resultados do projeto e, se ocorrerem, representam aumento dos lucros. A diretoria da empresa considera essas informações estratégicas para o 
empreendimento e define a divulgação dos riscos apenas ao gerente do projeto e à administração contratual.

De maneira semelhante ao que ocorre nos projetos da empresa $A$, a análise dos riscos e oportunidades dos projetos da empresa $B$ se restringe à fase de identificação, para fins de orçamento e planejamento inicial do projeto, e esses dados não são compartilhados com os demais líderes das equipes. Dessa forma, a etapa de tratamento dos riscos é incompleta e apresenta falhas, uma vez que a principal parte interessada, que é a equipe de execução do empreendimento, não possui acesso às informações contidas nas planilhas de riscos e oportunidades. Como consequência, as equipes do projeto, desconhecendo as oportunidades, deixam de potencializar os resultados e se limitam a executar o empreendimento. Já os riscos, quando ocorrem, são tratados por essas equipes de forma isolada, e os valores incorridos não são registrados, ou seja, são aceitos e incorporados aos custos.

A condução do processo de gestão de riscos pela empresa B também caracteriza uma rotina de execução, em que não existe parâmetro para comparação dos custos reais incorridos com os valores inicialmente previstos.

\subsubsection{Gestão do processo de projeto}

Da mesma forma que a empresa A, para preparação da proposta de preços, a empresa $B$, contratada, já possui acesso aos projetos básicos do empreendimento que será construído. Mas, na maioria dos casos, esses projetos possuem pouca informação e pouco detalhamento. Além disso, as alterações do projeto básico em relação ao projeto executivo são significativas, o que impacta no planejamento e custos definidos na proposta.

Nos empreendimentos de grande porte da empresa, como é o caso do projeto $\mathrm{B} 1$, é feita uma reunião de kick-off-meeting (KOM) com o cliente, mesmo para o caso em que o cliente faz parte do grupo. Nessa reunião, são apresentadas, ao cliente, por meio do gerente do projeto, informações referentes ao plano de ataque geométrico para execução do projeto, ou seja, quais os métodos para 
execução do escopo contratado para cumprimento das principais datas marcos; a estrutura analítica do projeto (EAP), compatível ao cronograma de planejamento da obra, que apresentava a linha de base para atendimento aos prazos contratuais, utilizando o software Project, apresentação das principais lideranças do projeto; entre outros assuntos técnicos.

A empresa B não possui uma gestão do processo de projeto bem definida. A alocação de pessoas, que compõem a equipe de projetos, varia de acordo com o porte dos empreendimentos e com a responsabilidade dos projetos, sendo esta, uma decisão seletiva da diretoria da empresa.

Para contratos de construção, em que o cliente é responsável pela elaboração dos projetos, a empresa $B$ avalia o grau de complexidade do empreendimento para definir se é necessário ou não compor uma equipe dedicada aos projetos. Como consequência, em alguns empreendimentos, não é feita a análise crítica, a compatibilização dos projetos e a verificação de detalhes e informações necessárias aos projetos para execução. Dessa forma, os erros ou inconsistências são identificados durante a execução do empreendimento, o que impede o bom andamento dos serviços, causando atrasos e acréscimos de custo.

Para empreendimentos, cuja contratação é do tipo Engineering, procurement and construction (EPC), a empresa $\mathrm{B}$ é responsável pela elaboração dos projetos. Por isso, define uma equipe destinada à gestão do processo de projetos. Essa equipe é composta por profissionais que ficam alocados no empreendimento e na sede da empresa no Brasil. Os profissionais da sede da empresa fazem a interface dos projetistas com o empreendimento, e os profissionais do empreendimento fazem a interface da sede com 0 empreendimento.

No estudo de caso B1, a elaboração dos projetos executivos é de responsabilidade da empresa B. As principais entregas contratuais são detalhadas no cronograma de execução do empreendimento, e essas 
informações são repassadas para a projetista. A relação entre o cronograma de execução e a entrega dos projetos executivos permite um prazo de análise confortável para a equipe de coordenação de projetos, o que diminui bastante 0 percentual de erros relacionados aos projetos para execução. A figura 15 apresenta o fluxo de informações de projeto.

Figura 15 - Fluxograma de projetos da empresa B

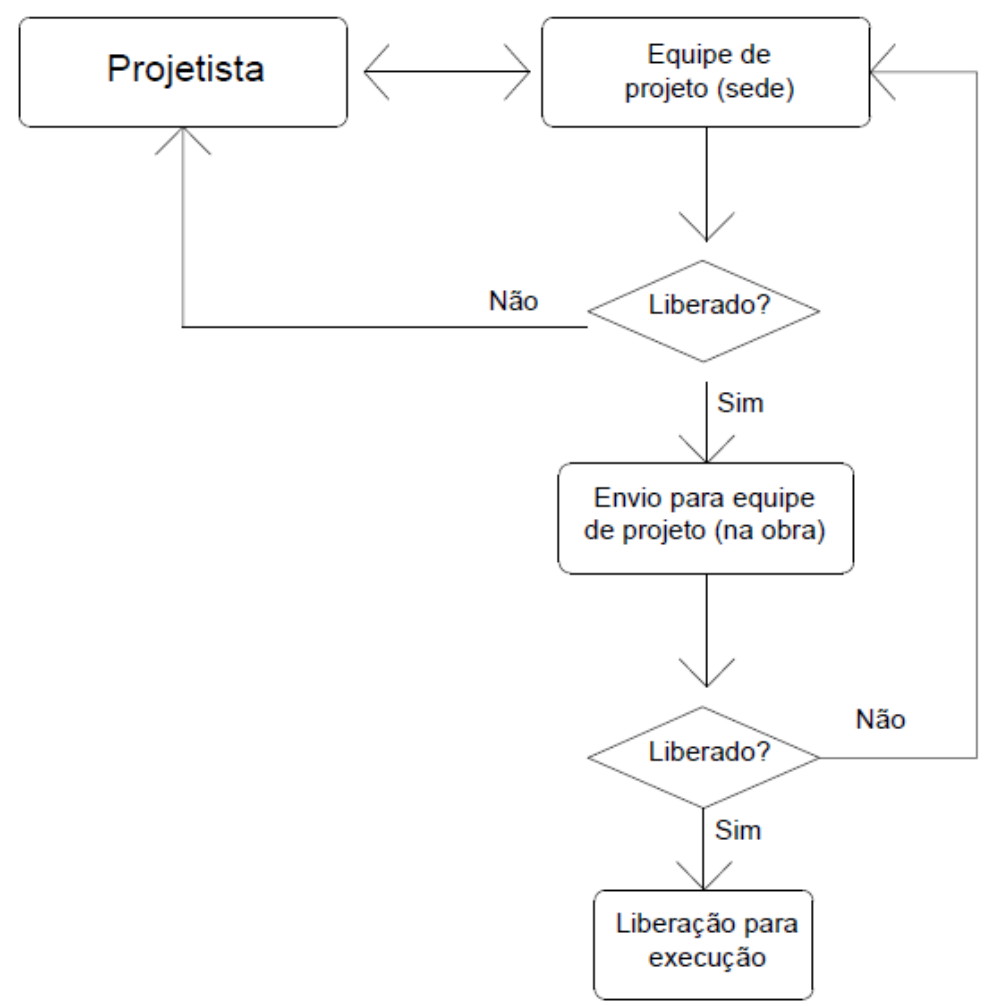

Fonte: dados da pesquisa

O coordenador de projetos fica alocado na sede da empresa e tem como atribuições a contratação de projetistas; o envio de projetos básicos; o recebimento de projetos executivos; a análise crítica e compatibilização de projetos; as revisões, quando necessário; e o envio dos projetos aprovados para a obra. Já a obra atribui um engenheiro da equipe de planejamento como responsável pela análise dos projetos para produção, distribuição de projetos liberados e descarte dos projetos obsoletos. Dúvidas ou inconsistências de projetos identificados em obra são reportadas para a equipe da sede. 


\subsubsection{Gestão da informação e do conhecimento}

A empresa $B$ possui um banco de dados que armazena informações e conhecimentos de projetos anteriores como relatório final de obra, relatórios de gestão de produtividades, índices de custo, lições aprendidas e procedimentos de qualidade e segurança do trabalho. Esses dados podem ser consultados na intranet da empresa por todos os colaboradores, de acordo com a necessidade de acesso de cada um. Informações estratégicas para a empresa, como o caso de relatórios econômicos e financeiros, são restritas aos cargos de diretoria e gerência. Para acessar os dados no sistema, os colaboradores recebem um treinamento da equipe de tecnologia da informação.

Todas as informações produzidas nos projetos são validadas pelos gerentes das áreas, antes de serem inseridas no banco de dados da intranet. No entanto, não existe uma política de feedback para os colaboradores no que se refere à valorização dessas informações. O que existe, em outra linha estratégica, é a valorização dos projetos de inovação produzidos pelos colaboradores e que representam um ganho de produtividade ou um novo método construtivo.

A empresa também busca o aprimoramento contínuo do processo de armazenamento e uso da informação e conhecimento, uma vez que os dados compartilhados são importantes para início de novos projetos e criação de novas soluções técnicas.

\subsubsection{Gestão da comunicação}

A empresa B não possui um processo formal para a gestão da comunicação interna das equipes. No entanto, o projeto estudado permitiu a promoção de reuniões semanais com as principais lideranças para tratar pontos críticos considerados estratégicos para o projeto. Essas informações foram repassadas para cada equipe por meio de reuniões setoriais. 
Já a comunicação externa com o cliente, órgãos reguladores e subcontratados, é formal, por meio de cartas e e-mails. Esse registro auxilia o trabalho do setor de administração contratual.

\subsection{Empresa C}

\subsubsection{Caracterização da empresa}

Trata-se de uma empresa nacional fundada em 1947, atuando, inicialmente, no segmento de infraestrutura, com obras de pavimentação e saneamento. Em 1992, após a fusão com uma empresa dinamarquesa, adquiriu expertise para atuar em obras marítimas. Também opera nos segmentos de construção imobiliária e concessões rodoviárias e de saneamento. Possui matriz no Rio de Janeiro (RJ) e uma filial em São Paulo (SP). Tem uma estrutura organizada por segmentos de atuação no mercado (Figura 16).

Figura 16 - Organograma da empresa C

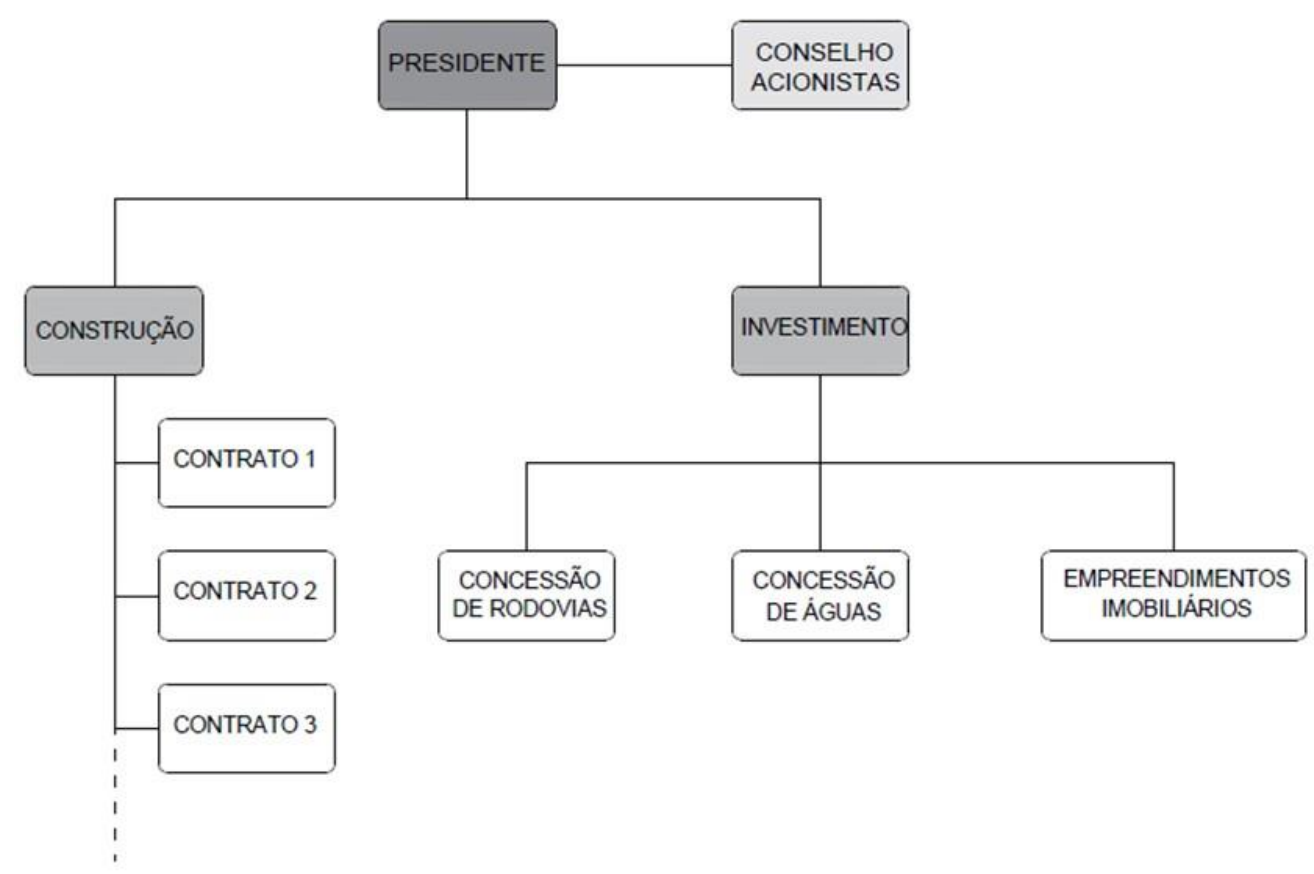

Fonte: dados da empresa

Para todos os projetos que serão iniciados ou que estão em andamento, a empresa adota como principais estratégias: (1) o levantamento de informações 
de lições aprendidas, referente ao banco de dados de registro de projetos semelhantes; (2) a preparação de um banco de dados próprio do projeto, denominado "pasta da obra", onde constam todos os arquivos necessários ao início da obra, como: contrato assinado, planilhas orçamentárias, composições de custos, projetos básicos, projetos executivos, se houver, planilha de riscos, entre outras informações; (3) levantamento e análise qualitativa e quantitativa dos riscos, por meio de consulta de arquivos armazenados no banco de dados da empresa e reuniões gerenciais; (4) elaboração de reunião inaugural (RI) interna para definição do resultado do projeto, entre equipe de obra e a diretoria da empresa, além de reuniões de acompanhamento desse resultado, acordado entre as partes; (5) elaboração de planejamentos físico-financeiros a cada quatro meses; e (6) levantamento das partes interessadas no projeto.

Com base nesses dados, a gerência de contratos consegue atualizar as informações dos projetos em tempo, além de aumentar o controle da diretoria da empresa sobre o andamento da obra, possibilitando interferências e ajustes sempre que necessário. Por exemplo, a reunião inaugural contém as seguintes informações: dados contratuais (prazos, multas etc.); principais líderes do projeto e plano de treinamento para crescimento de cada um; principais serviços e principais quantitativos do projeto para controle dos mesmos; destaque para a equipe de projeto (design); cronograma físico; datas marco; premissas para o reorçamento da obra, umas vez que os projetos executivos diferem dos projetos básicos; análise de desvios de custo e prazo; atualização de riscos identificados e inclusão de novos riscos, se for o caso; proposta para melhorias no projeto, com objetivo de recuperar prazo e custo; indicadores de qualidade, segurança, meio ambiente e saúde; relacionamento com a comunidade; metas empresariais e institucionais; inovações tecnológicas; itens para atestação de obra; e outros pontos que forem pertinentes.

O resultado da reunião inaugural é "congelado" pela diretoria da empresa, ou seja, é registrado formalmente no sistema integrado para acompanhamento. No final do projeto, é apresentado em uma reunião final ou reunião de fechamento $(\mathrm{RF})$. Se os resultados finais foram maiores que os inicialmente previstos, a diferença de valor é compartilhada pela diretoria e equipe da obra. Além disso, 
as justificativas que ocasionaram o resultado positivo são registradas como lições aprendidas para futuros projetos. No caso inverso, se os resultados finais forem menores que os inicialmente previstos, é necessário apresentação das justificadas que ocasionaram o desvio negativo, também para registro das lições aprendidas. Todas as informações são registradas no relatório final de obra, documento que é compartilhado com outros projetos que estão em fase inicial.

Tais informações também são compartilhadas com toda a equipe de líderes do projeto, o que mantém o alinhamento com as metas necessárias para alcançar os objetivos propostos. Já os documentos de acompanhamento auxiliam na tomada de decisão quanto às tratativas necessárias para a manutenção desses objetivos.

\subsubsection{Caracterização dos casos $\mathrm{C} 1$ e $\mathrm{C2}$}

O primeiro estudo de caso da empresa $\mathrm{C}$, que será denominada (C1), consiste na elaboração de projetos executivos e na execução das obras das estruturas de atracação de um cais de apoio offshore, com extensão de 900 metros e do terminal de múltiplo uso, com extensão de 500 metros, como parte das obras de um importante porto, localizado no norte fluminense.

O segundo caso da empresa $\mathrm{C}$, considerada como (C2), consiste na elaboração de projeto executivo, fornecimento de bens e prestação de serviços, relativos à construção e à montagem do píer do terminal de regaseificação na Bahia. Nesse projeto, a empresa utiliza um equipamento inovador, desenvolvido especialmente para cravação de estacas e montagem de elementos prémoldados.

A estrutura organizacional do projeto é do tipo projetizada, ou seja, o gerente de projetos tem total autonomia sobre as equipes. Estas são independentes para cada projeto. Além disso, a comunicação torna-se mais fácil no canteiro de obra e as equipes são mais autônomas para executar as atividades (Figura 17).

Os projetos da empresa C possuem equipes distintas, lideradas por gerentes funcionais, que por sua vez são liderados por um gerente de projeto, responsável 
por fazer as mediações entre o cliente (contratante) e a diretoria da empresa (contratada). Os principais agentes envolvidos na execução do projeto são:

- cliente (contratante) - composto por uma equipe multidisciplinar que avalia as atividades da empresa $\mathrm{C}$ (contratada) por pares;

- diretoria da empresa C - composta por um diretor operacional e um diretor comercial. O primeiro é responsável por assessorar a equipe de obra, no que se refere a questões técnicas, operacionais, financeiras, contratações de consultorias etc. O segundo é responsável por atuar comercialmente, junto ao cliente, buscando captar novos projetos. Também auxilia a equipe de obra na manutenção de uma boa imagem para o cliente;

Figura 17 - Organograma dos projetos da empresa C

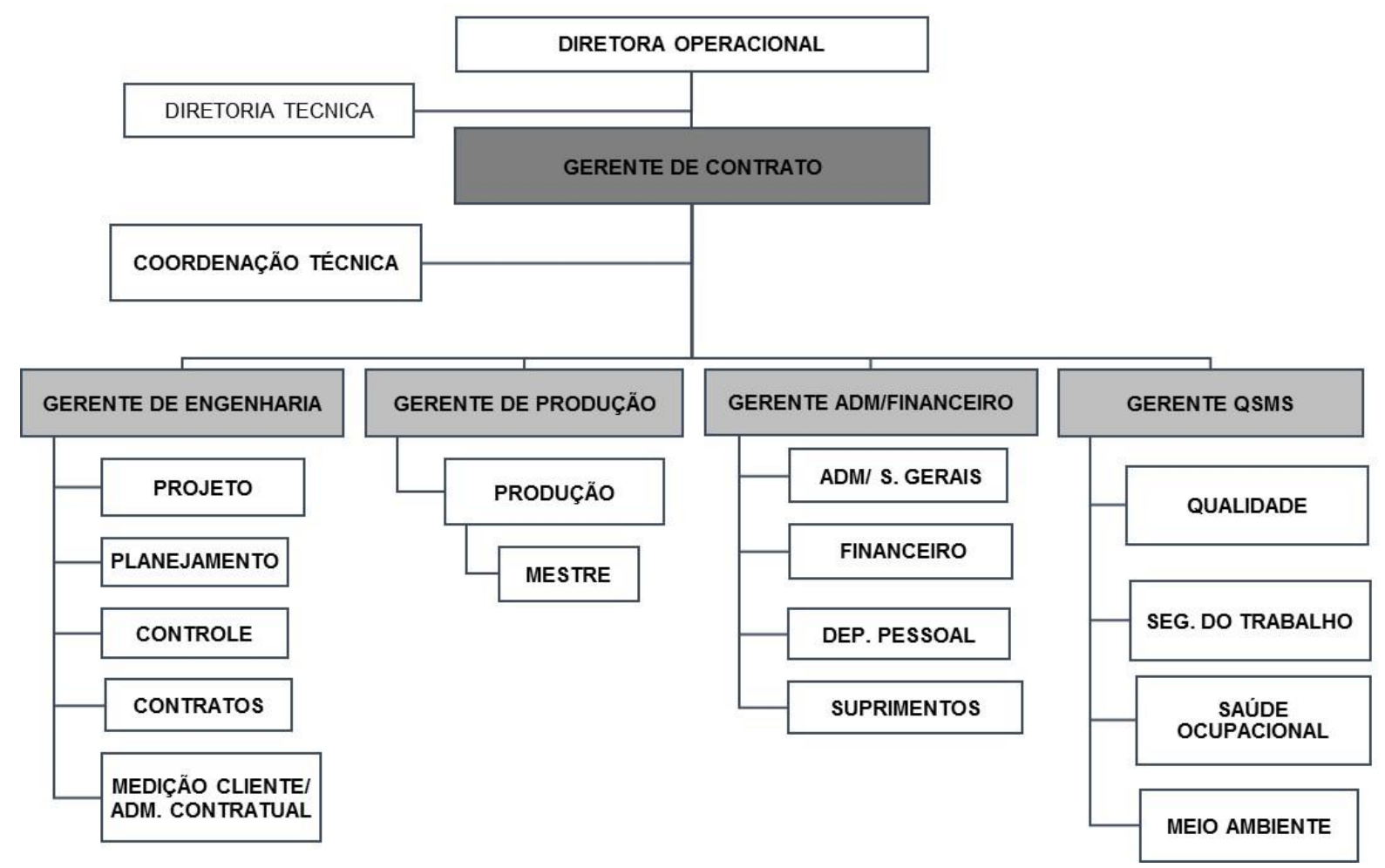

Fonte: dados da pesquisa

- gerente de projeto (de contrato) - principal autoridade da obra. Tem total autonomia sobre as equipes, podendo demitir e contratar sempre que 
julgar necessário, subcontratar recursos, consultorias e demais itens imprescindíveis para a execução do projeto;

- gerentes funcionais - são quatro: (1) gerente de engenharia, responsável pelas áreas de planejamento, custos, projetos (design), contratações de serviços e compras de materiais; (2) gerente de produção, responsável pela gestão das equipes de execução da obra, (3) gerente de qualidade, segurança do trabalho, meio ambiente e saúde (QSMS), responsável pela gestão das equipes de laboratório, segurança do trabalho, interface com o meio ambiente e medicina do trabalho; e (4) gerente administrativo/financeiro, responsável pela gestão das equipes administrativas (recursos humanos, segurança patrimonial, serviços gerais, logística, Tl etc.) e pagamento e prestação de contas; e

- consultoria externa -pessoas ou empresas contratadas pelo gerente de projetos e/ou diretoria para apoio nas atividades do projeto e proposição de soluções técnicas.

No caso da empresa $C$, as equipes são pequenas, em torno de 4 a 5 funcionários, além do gerente da área. As equipes atendem aos seus gerentes que, por sua vez, respondem ao gerente de contrato. Essa hierarquia, bem definida, contribui com os resultados dos projetos, pois as equipes, mesmo pequenas, trabalham em conjunto para atingir o mesmo resultado.

\subsubsection{Gestão de riscos}

A empresa $C$ possui um padrão para análise de riscos em períodos determinados. A primeira análise ocorre antes do início do projeto e auxilia na definição de métodos construtivos, contratação dos principais serviços e definição da reserva de contingência. As demais análises ocorrem a cada 3 meses, após o início do projeto e auxiliam na justificativa dos riscos efetivos e na definição de novos riscos. A análise trimestral é feita, em conjunto, com base em um documento chamado planejamento anual. Nesse documento constam dados econômicos e financeiros do projeto. 
Os riscos são contingenciados, conforme a previsão de ocorrência, por meio das análises qualitativa e quantitativas. Essa contingência é incluída no planejamento anual, tendo em vista que a ocorrência desses riscos pode impactar nos resultados previstos. A análise de riscos dos projetos está evidenciado na Tabela 6.

A empresa também identifica as oportunidades que podem melhorar os resultados dos projetos. Essas oportunidades são identificadas em cada reunião de controle, apresentada para a diretoria da empresa, e são incorporadas aos resultados como metas de superação.

Tabela 6 - Análise de riscos dos projetos da empresa C

\begin{tabular}{|c|c|c|c|c|}
\hline Risco identificado & $\begin{array}{l}\text { Impacto } \\
\text { KR\$ }\end{array}$ & $\begin{array}{l}\text { Probabilidade } \\
\text { de ocorrência }\end{array}$ & Contingência & Ação mitigadora \\
\hline $\begin{array}{l}\text { Condições climáticas } \\
\text { adversas para cravação de } \\
\text { estacas (ventos fortes) }\end{array}$ & 4.816 & $70 \%$ & 3.371 & $\begin{array}{l}\text { Monitiramento dos ventos e } \\
\text { implantação de procedimento } \\
\text { para paralisação }\end{array}$ \\
\hline $\begin{array}{l}\text { Equipamento para cravação } \\
\text { de estacas }\end{array}$ & 3.122 & $50 \%$ & 1.561 & $\begin{array}{l}\text { Cravação alternativa e } \\
\text { monitoramento da produção }\end{array}$ \\
\hline $\begin{array}{l}\text { Demora na aprovação / } \\
\text { liberação de projetos }\end{array}$ & 2.408 & $50 \%$ & 1.204 & $\begin{array}{l}\text { Acompanhamento de } \\
\text { projetistas, revisores e cliente }\end{array}$ \\
\hline $\begin{array}{l}\text { Retrabalhos após a } \\
\text { dragagem }\end{array}$ & 2.550 & $30 \%$ & 765 & \\
\hline Total & 12.896 & & 6.901 & \\
\hline
\end{tabular}

Fonte: dados da pesquisa

\subsubsection{Gestão do processo de projeto}

Da mesma forma que os casos anteriores, para preparação da proposta de preços, a empresa contratada já possui acesso aos projetos básicos do empreendimento que será construído. Mas, na maioria dos casos, esses projetos possuem pouca informação e pouco detalhamento do que será construído. Além disso, as alterações do projeto básico em relação ao projeto executivo são significativas, o que impacta no planejamento e custos definidos na proposta. 
Nas obras de grande porte da empresa, como é o caso dos projetos C1 e C2, é feita uma reunião de kick-off-meeting (KOM) com o cliente. Nessa reunião, são apresentadas ao cliente, por meio do gerente do projeto, informações referentes ao plano de ataque geométrico para execução do projeto, ou seja, quais os métodos construtivos para execução do escopo contratado para cumprimento das principais datas marcos; a estrutura analítica do projeto (EAP), compatível ao cronograma de planejamento da obra, que apresentava a linha de base para atendimento aos prazos contratuais, utilizando o software Project; apresentação das principais lideranças do projeto; entre outros assuntos técnicos.

A empresa $C$ possui uma equipe que trabalha especificamente na análise de projetos, em conformidade com o organograma deles, de acordo com a Figura 18.

Figura 18 - Organograma da equipe de projetos da empresa C

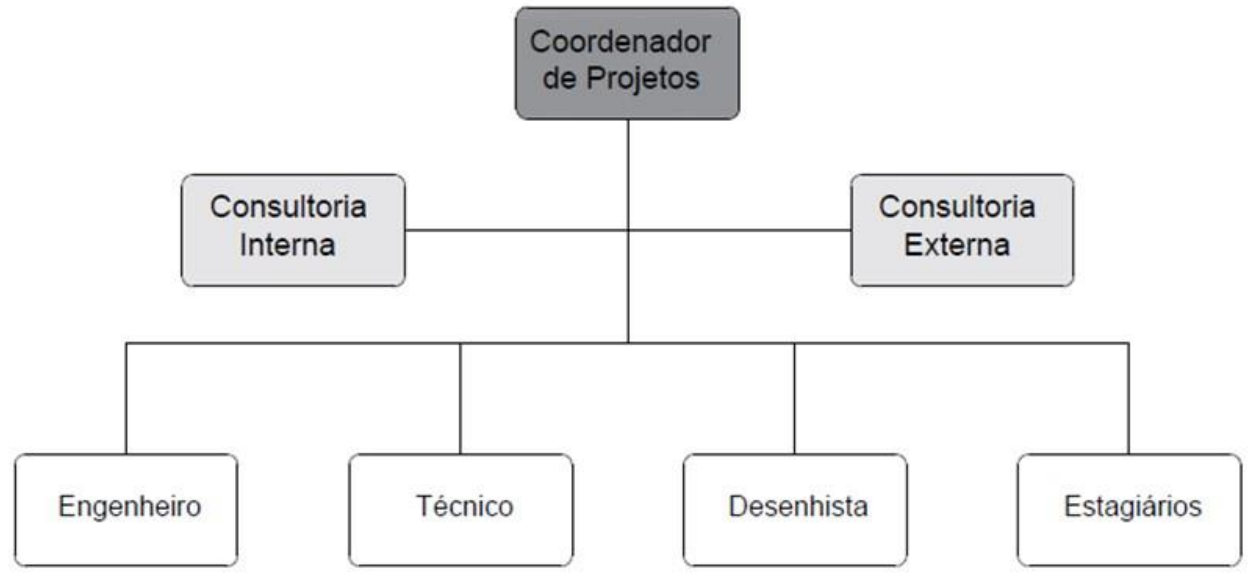

Fonte: dados da empresa

A equipe de projetos (design), pode-se perceber pelo organograma acima, é formada por um coordenador de projetos, que atua na interface entre o consultor interno da empresa e consultores externos, coordena os membros da equipe de projeto da obra na elaboração de análise crítica, compatibilidade, detalhamento de peças, quando necessário, entre outras atividades; um engenheiro sênior, que trabalha como um consultor interno de projetos; um engenheiro civil, responsável pela análise crítica e de compatibilidade; um técnico para auxiliar 
nas atividades do setor; um desenhista para operação de softwares para elaboração de desenhos auxiliares; e outros técnicos e estagiários responsáveis por alimentar a planilha de recebimento de projetos e substituição de projetos defasados no campo. Os consultores externos, também chamados de revisores, podem ser um ou dois projetistas, o que depende do porte e da complexidade dos projetos.

A contratação dos revisores independe da responsabilidade do projeto, ou seja, se o projeto for de responsabilidade da empresa C ou do cliente, haverá contratação de revisores.

No primeiro estudo de caso, conforme visto anteriormente, os projetos são de responsabilidade do cliente (contratante) e no segundo de responsabilidade da empresa $\mathrm{C}$, contratada para execução das obras civil e da montagem industrial. A Figura 19, a seguir, apresenta como se realiza o fluxo de informações de projeto da empresa $\mathrm{C}$.

Figura 19 - Fluxograma de projetos da empresa C

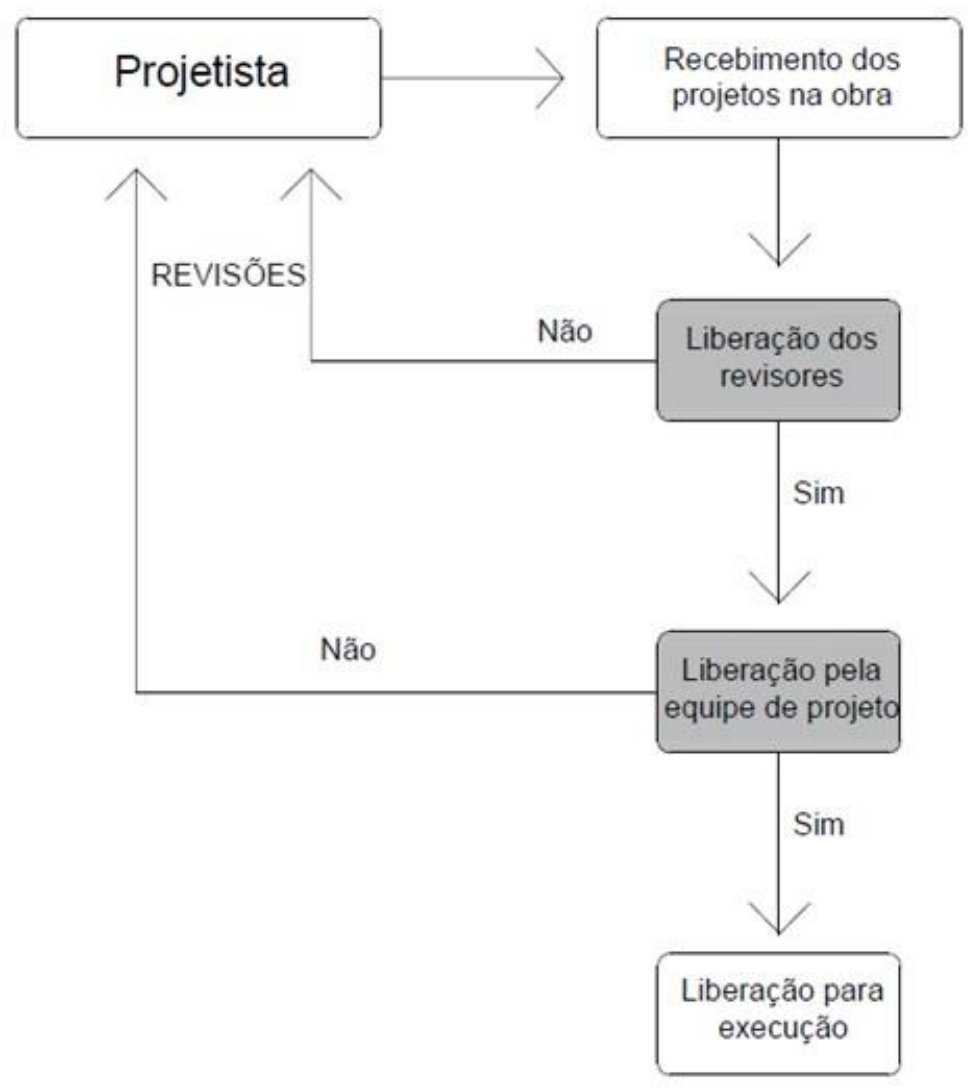

Fonte: dados da pesquisa 
Fácil notar, pelo organograma acima, que o coordenador de projetos também é responsável pela contratação e pela interface com as empresas projetistas. As informações do projeto são analisadas desde o recebimento pelo coordenador de projetos. Após investigação do coordenador, os projetos são enviados para os revisores externos. No caso de comentários ou sugestões de revisão, o coordenador avalia as informações, junto com o consultor interno da empresa, e decide a necessidade de revisão pelo projetista.

Em paralelo à análise dos revisores, também ocorre a análise crítica e de compatibilidade dos projetos. Havendo necessidade de revisão, os projetos são enviados para a empresa projetista. Caso contrário, os projetos são liberados e distribuídos para a equipe de produção. Os projetos obsoletos são recolhidos e descartados. Esse fluxograma garante informações mais precisas e diminuiu a possibilidade de erros relacionados a projetos.

A análise de projeto também envolve a identificação de itens novos, que não constam na planilha de quantidades licitada, além de serviços com aumento ou redução de quantidades. Essa análise é importante para definição de novos preços, necessários para a execução dos serviços; atualização do cronograma do projeto; e atualização dos resultados.

\subsubsection{Gestão da informação e do conhecimento}

A empresa C também possui um banco de dados para armazenamento e distribuição de informações e conhecimentos. Essa distribuição ocorre de duas formas. A primeira é uma rede interna que possui dados, como relatório final de obra, orçamentos para licitação, contratos com subcontratados, planejamentos anuais, planilha de riscos, lições aprendidas e procedimentos de qualidade e segurança do trabalho. Os dados podem ser consultados na intranet da empresa por todos os colaboradores, de acordo com a necessidade de acesso de cada um. Informações estratégicas para a empresa, como o caso de relatórios econômicos e financeiros, são restritas aos cargos de diretoria e gerência. A segunda é um sistema integrado, criado pela empresa para compartilhamento 
de dados de outros projetos como composições de custos; planilhas de custos diretos e indiretos; medições de subcontratados; controles de perdas de materiais; entre outros.

Todas as informações produzidas nos projetos são validadas pelos gerentes das áreas antes de serem inseridas no banco de dados da intranet. No caso do sistema integrado, as informações são inseridas de forma estratégica para que a diretoria dos projetos tenha acesso a relatórios de controle de perdas, desvios de custo, resultados econômicos, valores pagos para subcontratados tanto mensais quanto acumulados. Esse acompanhamento permite à diretoria atuar nos desvios mais significativos. Para trabalhar com o sistema integrado, a equipe do projeto recebe treinamento específico.

A empresa $\mathrm{C}$ também possui um plano de metas institucionais em cada projeto, em que são definidas estratégias para a formação de novas lideranças de equipes. Assim, os gerentes de setores são responsáveis por formar outros líderes; difundir aspectos inovadores da empresa e do projeto; e atuar na melhoria de processos existentes.

Como forma de compartilhar conhecimento com todos os funcionários, a empresa criou uma revista de circulação interna, que divulga informações sobre os projetos e soluções técnicas desenvolvidas pelas equipes dos projetos. A empresa também promove premiações, como forma de reconhecimento de boas ideias e soluções inovadoras, além de oferecer treinamentos periódicos para os funcionários.

Por fim, a empresa busca o aprimoramento contínuo do processo de armazenamento e uso da informação e do conhecimento, uma vez que os dados compartilhados são importantes para início de novos projetos, melhoria de processos e criação de novas soluções técnicas. 


\subsubsection{Gestão da comunicação}

Os projetos da empresa $C$ não possuem um plano de comunicação interno formal. Dessa forma, a comunicação entre as equipes ocorre por meio de reuniões semanais descentralizadas, o que gera a segregação das informações. Após identificação do problema, o gerente de projetos do estudo de caso (C2) contratou uma empresa de consultoria. Esta implementou novos meios de comunicação e melhorou outros. Algumas soluções adotadas pela equipe do projeto foram reuniões diárias de produção; reuniões semanais com as gerências das equipes; e implantação de painéis de gestão à vista, a fim de nivelar as informações sobre andamento do projeto para todos os envolvidos. Essas soluções causaram impactos positivos ao projeto e foram implementadas em outros projetos da empresa.

Já a comunicação externa com o cliente, órgãos reguladores e subcontratados ocorre de maneira formal, por meio de cartas, e-mails, atas de reuniões, entre outros, geridos pelo gerente de contrato.

\subsection{Empresa D}

\subsubsection{Caracterização da empresa}

Trata-se de um grupo global, de origem brasileira, criado em 1923, atuando, incialmente, no segmento de construção imobiliária. Em 1945, ampliou as atividades para construção de infraestrutura e, em 1984, expandiu os negócios para outros países. Atualmente, atua no Brasil e em mais 24 países. Possui negócios diversificados e estrutura descentralizada e organizada para atuação no mercado, presente nos segmentos de engenharia e construção, indústria, imobiliário e no desenvolvimento e operação de projetos de infraestrutura e energia (Figura 20). 
Figura 20 - Organograma da empresa D

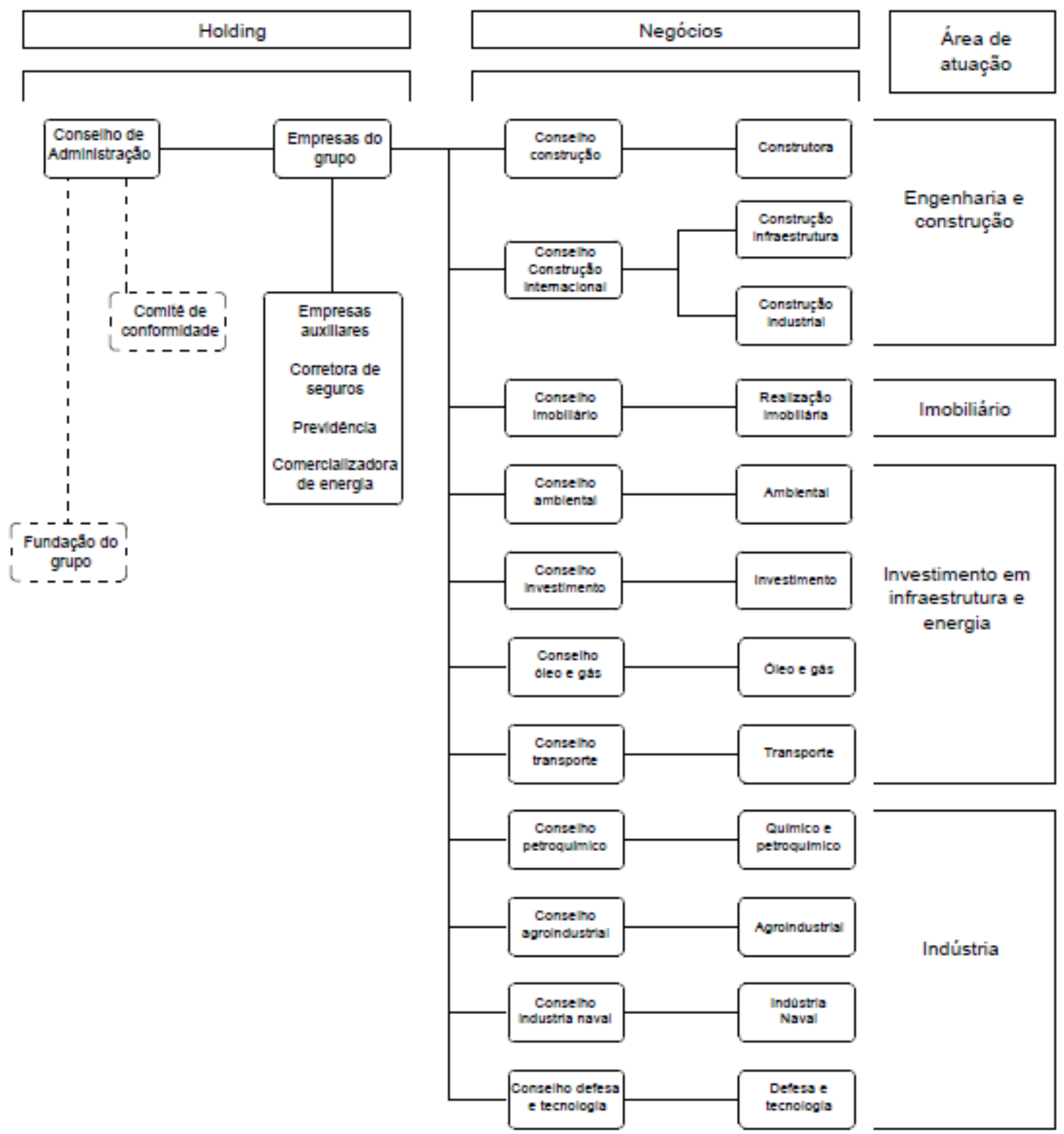

Fonte: dados da empresa

Para todos os projetos que serão iniciados ou que estão em andamento a empresa adota como principais estratégias: (1) o levantamento de informações de projetos anteriores, por meio da rede de compartilhamento de conhecimento digital da empresa; (2) preparação de um banco de dados próprio do projeto, onde constam todos os arquivos necessários para o início da obra, como: contrato assinado, planilhas orçamentárias, composições de custos, projetos básicos, projetos executivos, se houver, planilha de riscos, entre outras 
informações; (3) levantamento e análise qualitativa e quantitativa dos riscos; (4) análise crítica e levantamento de interferências dos projetos; (5) mapeamento das partes interessadas; e (6) elaboração de um plano de comunicação.

Tendo em vista os negócios e a área de atuação da empresa, conforme evidenciado na Figura 20, o efetivo de funcionários é de, aproximadamente, 80 mil. Destes, 55\% atuam no segmento de infraestrutura, sendo que do quantitativo geral $60 \%$ são brasileiros. Pode-se observar, na Tabela 7 , os dados relativos à nacionalidade dos funcionários.

Tabela 7 - Funcionários por nacionalidade

\begin{tabular}{cc|cc}
\hline Nacionalidade & Efetivo & Nacionalidade & Efetivo \\
\hline Brasileiros & 48.064 & Alemães & 147 \\
\hline Angolanos & 9.601 & Portugueses & 113 \\
\hline Colombianos & 4.628 & Cubanos & 90 \\
\hline Panamenhos & 3.874 & Ganenses & 47 \\
\hline Peruanos & 3.340 & Bolivianos & 42 \\
\hline Dominicanos & 2.802 & Espanhóis & 40 \\
\hline Equatorianos & 2.344 & Indianos & 39 \\
\hline Venezuelanos & 1.345 & Guatemaltecos & 39 \\
\hline Mexicanos & 1.148 & Paquistaneses & 37 \\
\hline Argentinos & 574 & Outras nacionalidades & 1.149 \\
\hline Norte-americanos & 153 & TOTAL & 79.616 \\
\hline
\end{tabular}

Fonte: dados da empresa

\subsubsection{Caracterização do caso D1}

O estudo de caso da empresa, que será denominado (D1), trata acerca de uma ponte. Esta faz parte da concretização de uma grande leva de investimentos recentes na remodelação viária dos bairros Morumbi e Chácara Santo Antônio, na zona Sul da cidade de São Paulo. Essa região abriga o principal eixo de desenvolvimento imobiliário da capital paulista, onde estão sendo erguidas edificações corporativas, residenciais e complexos comerciais. Em torno das obras da iniciativa privada, há um conjunto de projetos para desafogar o trânsito pesado nas vias, um dos principais gargalos da região. Grande parte dos 
recursos para execução do projeto foi custeada pelos títulos negociados dentro da Operação Urbana Água Espraiada (Oucae), aprovada em 2001, cujo orçamento é de $R \$ 3,4$ bilhões. Outra parte dos recursos foi uma demanda direta da prefeitura como contrapartida pelos mega empreendimentos que intensificarão o movimento de veículos nos arredores.

A estrutura organizacional do projeto é do tipo projetizada, ou seja, o gerente de projetos tem total autonomia sobre as equipes. Estas são independentes para cada projeto. Além disso, a comunicação torna-se mais fácil no canteiro de obra e as equipes são mais autônomas para executar as suas atividades, note-se pelo organograma dos projetos da empresa evidenciados na Figura 21.

Os projetos da empresa D possuem equipes distintas, lideradas por gerentes funcionais, que por sua vez são liderados pelo diretor de contrato, responsável por fazer as mediações entre o cliente (contratante) e a diretoria de contrato. As principais equipes envolvidas na execução do projeto são:

- diretor de contrato - principal autoridade da obra. Tem total autonomia sobre as equipes, podendo demitir e contratar sempre que julgar necessário, subcontratar recursos, consultorias e demais itens imprescindíveis para a execução do projeto;

- gerente de saúde, segurança do trabalho e meio ambiente (SSTMA): realiza a gestão das equipes de laboratório, segurança do trabalho, interface com o meio ambiente e medicina do trabalho. Responde diretamente ao diretor de contrato;

- gerente de produção: responsável pela gestão das equipes de execução da obra, inclusive assuntos relacionados a interferências de projeto na execução;

- gerente comercial: responsável pelo setor de custos, medição do cliente e de subcontratados, e administração contratual;

- gerente administrativo/financeiro, responsável pela gestão das equipes administrativas (recursos humanos, segurança patrimonial, serviços gerais, logística, TI etc.); 
- gerente de engenharia, responsável pelas áreas de planejamento, projetos (design), e interface de projeto com agentes externos (concessionárias) que possuem interferências.

Figura 21 - Organograma dos projetos da empresa D

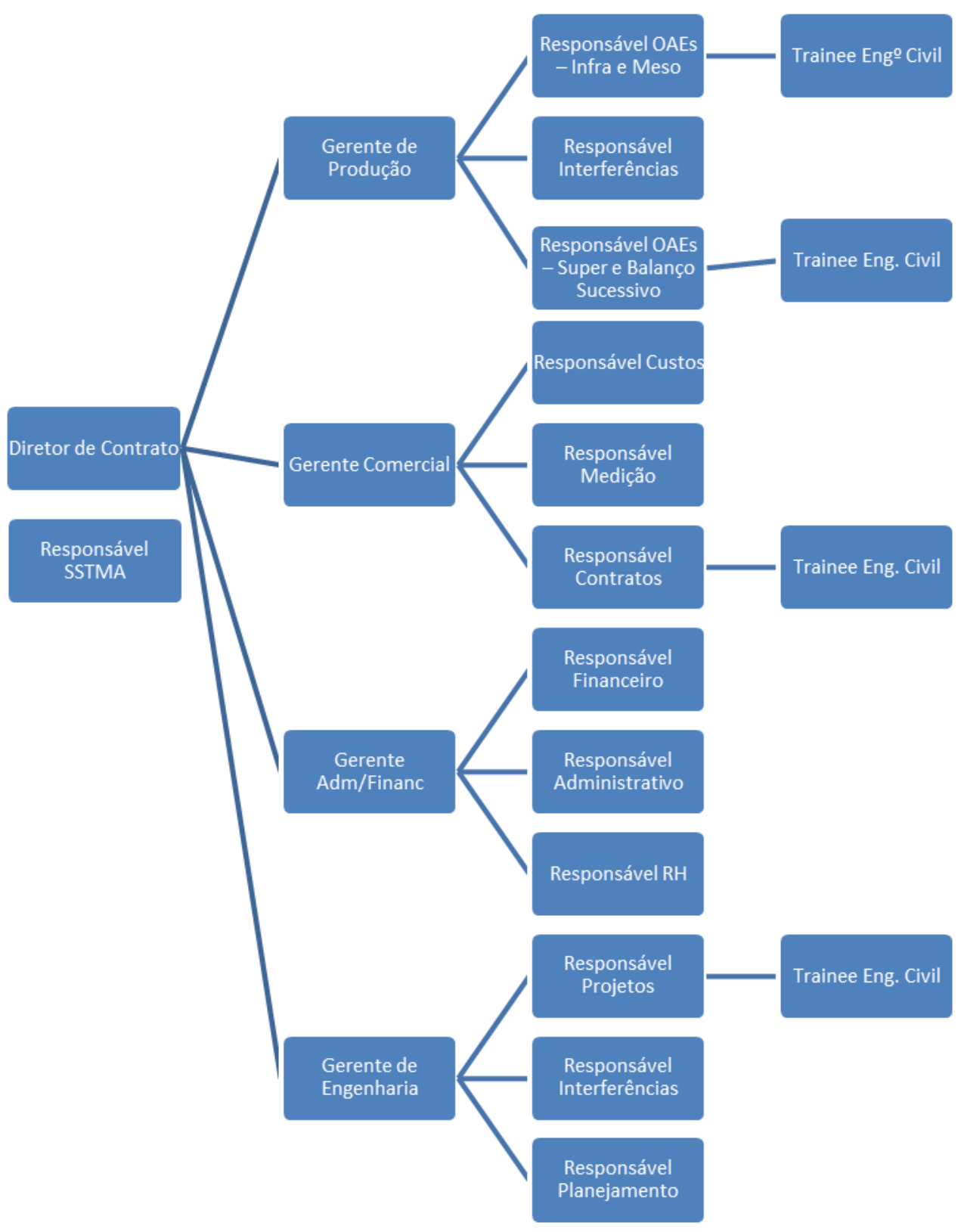

Fonte: dados da empresa

Cabe destacar que a empresa investe parte de seus recursos no treinamento de novos engenheiros. Esse fato justifica um engenheiro trainee em cada equipe do projeto. 


\subsubsection{Gestão de riscos}

A empresa $\mathrm{D}$ adota um processo iterativo para análise de riscos do projeto. $\mathrm{Na}$ fase inicial, uma equipe, composta por gerentes, coordenadores de produção e de engenharia, e engenheiro de segurança do trabalho, promove várias rodadas de reuniões para definir os riscos que podem afetar o projeto. A equipe utiliza como auxilio, - além de informações disponíveis na intranet sobre outros projetos que possibilitam comparar, interpretar e discutir dados ocorridos em casos semelhantes -, uma matriz padrão de incertezas, dividida em categorias, de acordo como o Quadro 11.

Quadro 11 - Categorias de incertezas da empresa D

\begin{tabular}{|c|c|c|c|}
\hline \multicolumn{4}{|c|}{ Fatores de incerteza } \\
\hline 1. & Incerteza contratual & 4. & Incerteza da administração \\
\hline 1.1. & Descumprimento de obrigações contratuais & 4.1. & Segurança \\
\hline 1.2 . & Força maior & 4.2. & Problemas laborais \\
\hline 1.3. & Garantias demandadas pelo cliente & 4.3. & Gastos com a comunidade \\
\hline 1.4. & Seguros demandados pelo cliente & 4.4. & Gastos com a imprensa \\
\hline 1.5. & Franquias dos seguros assumidos pelo cliente & 4.5. & Legais e de regulamentos \\
\hline 1.6. & Responsabilidade civil & 5. & Incerteza política \\
\hline 2. & Incerteza de engenharia & 5.1. & Alteração de legislação \\
\hline 2.1. & Sub-solo & 5.2. & Desordem pública \\
\hline 2.2 . & Ambiental & 5.3. & Quebra de contrato \\
\hline 2.3. & Interferências & 5.4. & Inconversibilidade da moeda \\
\hline 2.4 . & Projeto & 6. & Incerteza como Investidor \\
\hline 2.5 . & Humanas & 6.1. & Ambiental \\
\hline 2.6. & Materiais & 6.2 & Projeto \\
\hline 2.7. & De construção & 6.3. & Cumprimento do cronograma \\
\hline 2.8. & Acurácia do "custo puro" & 6.4. & Quebra de contrato \\
\hline 3. & Incerteza econômico-financeira & 6.5. & Crédito \\
\hline 3.1. & Demandas da segurança empresarial & 6.6. & Operação e manutenção do empreendimento \\
\hline 3.3. & Inflação & & \\
\hline 3.4. & Desbalanceamento de moedas & & \\
\hline 3.5 . & Taxa de juros & & \\
\hline 3.6. & Taxas alfandegárias & & \\
\hline
\end{tabular}

Fonte: dados da empresa

A matriz padrão de incertezas da empresa $D$ possui opções para atribuir a responsabilidade pelos riscos, que podem ser do cliente, do fornecedor, do sócio, do seguro ou da empresa. Além disso, atua de acordo com a situação do risco, ou seja, tem uma maneira de agir quando o risco é "identificado" e outra se o risco é "não identificado". Para os riscos não identificados, a equipe do projeto faz uma reunião, a fim de definir o repasse de verbas previstas para outros riscos, que não ocorreram. Em se tratando do risco identificado, para cada um 
deles, verifica-se o custo previsto e a probabilidade de ocorrência, a fim de gerar o valor de contingência (Tabela 8).

O modelo de matriz de incerteza da empresa adotada para análise dos riscos do projeto não contempla as respostas para os riscos identificados. Estas são atribuídas caso a caso em reuniões no canteiro de obras. Por exemplo, para os riscos relacionados ao projeto (design) o gerente definiu a contratação de uma equipe de controle de qualidade do projeto (CQP), a fim de melhorar o desempenho do setor.

Tabela 8 - Matriz de risco dos projetos da empresa D

\begin{tabular}{|c|c|c|c|c|c|}
\hline Item & Categoria & Fatores de risco & $\begin{array}{l}\text { Valor do } \\
\text { risco }\end{array}$ & Prob. & $\begin{array}{l}\text { Contingência } \\
\text { (R\$) }\end{array}$ \\
\hline 1) & Projeto: & - Variação na quantidades de serviços contratados & 66.488 .135 & $15 \%$ & 9.973 .220 \\
\hline 2) & Contratual: & $\begin{array}{l}\text { - Multa por atraso no prazo ou inadimplência } \\
\text { - Mora por dia de atraso } \\
\text { - Franquia por ocasião de sinistros }\end{array}$ & $\begin{array}{l}3.744 .000 \\
1.000 .000\end{array}$ & $\begin{array}{c}100 \% \\
5 \%\end{array}$ & $\begin{array}{c}0 \\
3.744 .000 \\
50.000\end{array}$ \\
\hline 3) & Serviços: & - Subcontratados & 3.400 .000 & $100 \%$ & 3.400 .000 \\
\hline 4) & Materiais: & - Deficiências no fornecimento & & & 0 \\
\hline 5) & Planejamento: & $\begin{array}{l}\text { - Atraso na entrega da obra } \\
\text { - Atraso no início dos serviços } \\
\text { - Alteração do plano de ataque } \\
\text { - Indisponibilidade da área prevista para canteiro }\end{array}$ & $\begin{array}{c}3.883 .060 \\
5.824 .589 \\
16.622 .034\end{array}$ & $\begin{array}{c}100 \% \\
25 \% \\
15 \%\end{array}$ & $\begin{array}{c}3.883 .060 \\
1.456 .147 \\
2.493 .305 \\
0\end{array}$ \\
\hline 6) & Administrativo: & $\begin{array}{l}\text { - Insuficiência no fornecimento de energia } \\
\text { - Recuperação dos acessos rodoviários } \\
\text { - Insuficiência no fornecimento de água } \\
\text { - Greves / Tumultos } \\
\text { - Custo de mercado } \\
\text { - Reclamações trabalhistas }\end{array}$ & $\begin{array}{c}200.000 \\
200.000 \\
100.000 \\
431.451 \\
5.200 .000\end{array}$ & \begin{tabular}{|c|}
$5 \%$ \\
$10 \%$ \\
$10 \%$ \\
$10 \%$ \\
$100 \%$
\end{tabular} & $\begin{array}{c}10.000 \\
20.000 \\
10.000 \\
43.145 \\
5.200 .000 \\
0 \\
\end{array}$ \\
\hline 7) & Ambiental: & $\begin{array}{l}\text { - Licença ambiental do canteiro } \\
\text { - Derramanento de óleo sobre o solo } \\
\text { - Derramanento de óleo sobre rio / córregos } \\
\end{array}$ & $\begin{array}{l}1.941 .530 \\
400.000 \\
400.000 \\
\end{array}$ & $\begin{array}{l}10 \% \\
5 \% \\
5 \% \\
\end{array}$ & $\begin{array}{c}194.153 \\
20.000 \\
20.000\end{array}$ \\
\hline 8) & Comercial: & $\begin{array}{l}\text { - Clima, chuva acima do previsto } \\
\text { - Definição precisa do escopo }\end{array}$ & $\begin{array}{l}8.311 .017 \\
9.973 .220\end{array}$ & $\begin{array}{l}5 \% \\
10 \%\end{array}$ & $\begin{array}{l}415.551 \\
997.322\end{array}$ \\
\hline 9) & Financeiro: & $\begin{array}{l}\text { - Inflação acima do reajustamento } \\
\text { - Aumento de alíquotas de impostos }\end{array}$ & $\begin{array}{c}9.973 .220 \\
18.051 .529\end{array}$ & $\begin{array}{l}15 \% \\
5 \%\end{array}$ & $\begin{array}{l}1.495 .983 \\
902.576\end{array}$ \\
\hline 10) & Suprimentos: & - Atraso dos forncedores & 9.973 .220 & $20 \%$ & 1.994 .644 \\
\hline & & TOTAL & \multicolumn{2}{|l|}{166.117 .004} & 36.323.107 \\
\hline
\end{tabular}

Fonte: dados da empresa

Durante a execução do empreendimento também são discutidas as possíveis causas para ocorrência dos riscos e são previstos novos riscos para as fases seguintes. Esse processo de revisão reduz imprevistos e auxilia na condução dos trabalhos, no tempo e no custo previstos. 
Cabe ressaltar que, no caso do projeto analisado, não houve identificação de oportunidades. Mas, em outros projetos da empresa, quando são constatadas, o valor é reduzido no preço ofertado.

\subsubsection{Gestão do processo de projeto}

Nas obras de grande porte da empresa, como é o caso do projeto estudado, também é feita uma reunião de kick-off-meeting (KOM) com o cliente. Nessa reunião, são apresentadas informações referentes aos métodos construtivos para execução do escopo contratado para apresentação das principais lideranças do projeto; estrutura analítica do projeto; entre outros assuntos técnicos.

Semelhante ao que ocorre nos casos anteriores, para preparação da proposta de preços, a empresa contratada já possui acesso aos projetos básicos do empreendimento que será construído. Mas, na maioria dos casos, esses projetos possuem pouca informação e pouco detalhamento do que será construído. Além disso, as alterações do projeto básico em relação ao projeto executivo são significativas, o que impacta no planejamento e custos definidos na proposta. A fim de melhorar a qualidade dos projetos executivos, a empresa $D$ possui uma equipe que trabalha especificamente na análise de projetos (Figura 22).

A equipe de projetos da empresa $D$ é composta por um coordenador de projetos, que atua na interface da obra com os projetistas e coordena os membros da equipe no que se refere à elaboração de análise crítica, à compatibilidade, aos detalhamentos, quando necessário, entre outras atividades; dois engenheiros projetistas, responsáveis pela análise crítica e de compatibilidade dos projetos; e um técnico cadista, dedicado à operação de softwares para elaboração de desenhos auxiliares, bem como à atualização da planilha de recebimento de projetos e substituição de projetos defasados no campo. Quando necessário, os gerentes de projetos contratam consultorias externas para análise dos projetos, como foi o caso do projeto D1. A consultoria fica incorporada à equipe de coordenação de projetos e responde ao coordenador do setor. 
Figura 22 - Organograma da equipe de projetos da empresa D

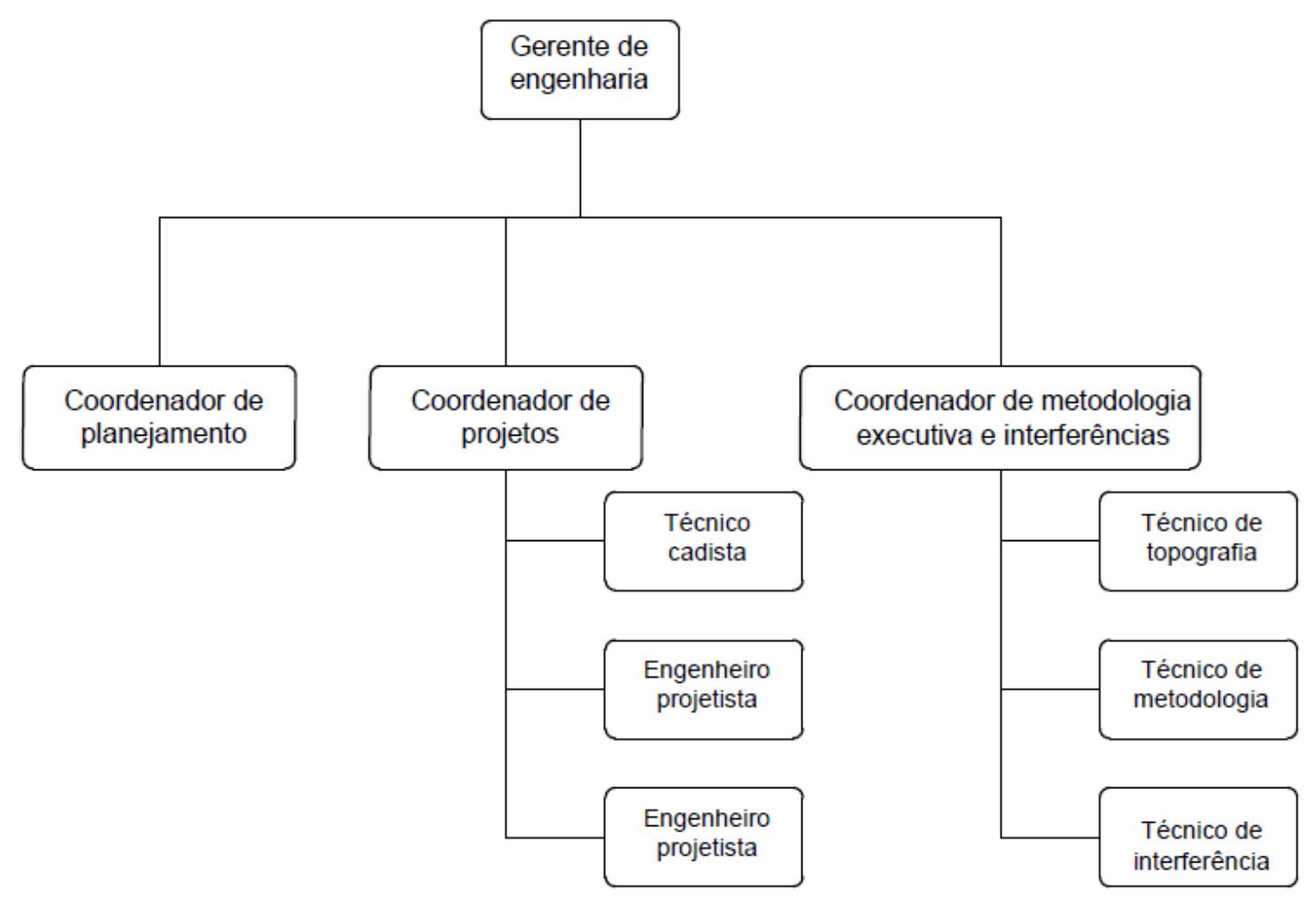

Fonte: dados da empresa

Um desafio surgido no projeto $D 1$ foi o relativo à administração das interferências com as concessionárias, em função da falta de desenhos de instalações existentes. Como solução, o gerente de engenharia criou uma equipe de métodos construtivos e interferências, com interface direta com a equipe de coordenação de projetos, uma vez que algumas das interferências identificadas em campo necessitavam de revisões de projetos. A Figura 23 apresenta o fluxo de informações de projeto da empresa $D$. Nesse caso os projetos são de responsabilidade do cliente (contratante).

As informações do projeto são analisadas desde o recebimento pela equipe de controle de qualidade do projeto (CQP). No caso de comentários ou sugestões de revisão, o coordenador avalia as informações e decide a necessidade de revisão pelo projetista. Se não houver comentários, o projeto segue para análise dos engenheiros projetistas da contratada. Em caso de comentários, os projetos retornam para a CQP. Caso contrário, são liberados e distribuídos para a equipe 
de produção. Os projetos obsoletos são recolhidos e descartados. Esse fluxograma garante informações mais precisas e diminuiu a possibilidade de erros relacionados ao projeto para execução.

Figura 23 - Fluxograma de projetos da empresa D

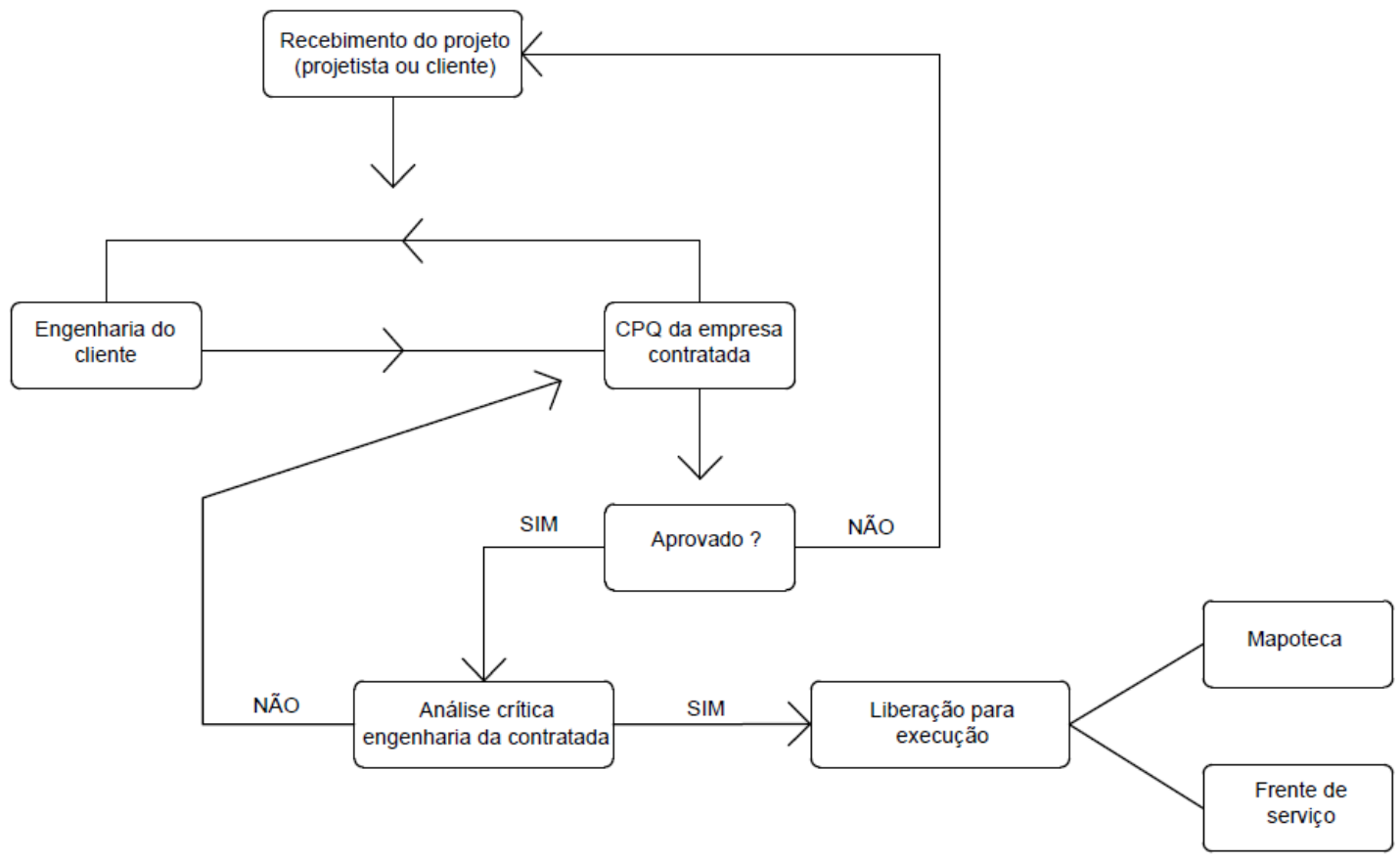

Fonte: dados da pesquisa

A empresa também investe em cursos institucionais e operacionais que são definidos no plano de ação (PA). Todos esses cursos, parte integrante do desenvolvimento de carreira dos profissionais envolvidos, estão ligados ao plano da qualidade. Os cursos visavam a qualificação dos funcionários, por exemplo, em leitura ou análise crítica de projetos.

No caso estudado, o nível de detalhe dos projetos enviados pelo cliente era insuficiente para execução do empreendimento. Por isso, a equipe de CPQ foi fundamental. Esta atuava na identificação da necessidade de informações para a produção, e os engenheiros projetistas na análise de interferências e mudança/melhoria dos métodos construtivos. O trabalho desenvolvido otimizou o fluxo de revisões, que ocorria em menor quantidade. Como exemplo, esse processo auxiliou na modificação dos métodos construtivos de toda a obra de arte especial, da infraestrutura, passando pela mesoestrutura até chegar à 
superestrutura. $\mathrm{Na}$ infraestrutura, a estaca do tipo tubulão foi modificada para estaca escavada em camisa metálica perdida. Na mesoestrutura, houve alteração na geometria dos pilares para garantir maior reaproveitamento de formas metálicas. E, na superestrutura, realizou-se a alteração do método de concreto moldado in loco para utilização de balaços sucessivos. A treliça utilizada para o balanço sucessivo é uma tecnologia espanhola. Por isso, a empresa precisou investir na pesquisa do equipamento, enviando o gerente da contrata para a Espanha, a fim de aprimorar o conhecimento sobre tal tecnologia. As alterações citadas representaram menor tempo de execução e menor custo para o cliente. A condução das alterações de projeto foi de responsabilidade do gerente do projeto, em conjunto com o coordenador da equipe de projetos.

\subsubsection{Gestão da informação e do conhecimento}

A empresa $D$ possui uma rede de compartilhamento de informações e conhecimento digital. Esses dados podem ser consultados na intranet da empresa por todos os colaboradores, de acordo com a necessidade de acesso de cada um. Informações estratégicas para a empresa, como o caso de relatórios econômicos e financeiros, são restritas aos cargos de diretoria e gerência do projeto. Os dados disponíveis para consulta são: composições de custos; planilhas orçamentárias; análise de riscos; fichários com informações de projetos semelhantes; entre outros. A equipe de qualidade é responsável por elaborar o fluxo de informações necessários para cada setor; armazenar os dados produzidos para consultas; e treinar as equipes para consultar os dados no sistema.

Um documento importante, produzido no projeto estudado, é um databook que possui dados técnicos de equipamentos específicos que são utilizados, como por exemplo, a treliça de balanço sucessivo, além de informações sobre lições aprendidas, especialmente no que se refere a imprevistos ocorridos durante a execução do projeto. O databook não é um documento obrigatório, ou seja, não é um documento exigido pela diretoria da empresa para entrega no final do projeto, mas são elaborados por alguns gerentes que já identificaram a sua importância estratégica para a empresa. Como exemplo, no caso estudado, o 
gerente do projeto consultou databooks produzidos por outros projetos para extrair dados de produtividade, riscos, avaliação de fornecedores, entre outros.

A empresa $D$ também possui um $P A$, onde estão definidas metas para formação de novas lideranças de equipes. Assim, alguns líderes, mais experientes, são responsáveis por formar outros líderes; difundir aspectos inovadores da empresa e do projeto; e atuar na melhoria de processos existentes.

Como forma de compartilhar conhecimento com todos os funcionários, a empresa criou uma revista de circulação interna que divulga informações sobre os projetos e soluções técnicas desenvolvidas pelas equipes dos projetos. A empresa também promove premiações, a fim de reconhecer boas ideias e soluções inovadoras propostas por seus colaboradores, além de promover treinamentos periódicos com os funcionários.

De maneira semelhante à empresa $\mathrm{C}$, a empresa $\mathrm{D}$ busca $\mathrm{o}$ aprimoramento contínuo do processo de armazenamento e uso da informação e conhecimento, uma vez que os dados compartilhados são importantes para o início de novos projetos e para a melhoria de processos e criação de novas soluções técnicas.

\subsubsection{Gestão da comunicação}

Como nos casos anteriores, os projetos da empresa $D$ não possuem um plano de comunicação interno formal. A comunicação entre as equipes do projeto ocorre por meio de reuniões semanais com as principais lideranças, além de reuniões setoriais isoladas. A fim de nivelar as informações com todos os envolvidos do projeto, a gerência implantou painéis de gestão à vista, onde são expostos o status do projeto e metas de produção para cumprimento semanal.

Já a comunicação externa com o cliente, órgãos reguladores e subcontratados é formal, por meio de cartas, e-mails, atas de reuniões, entre outros geridos pelo setor de administração contratual. 


\subsection{ANÁLISES DOS ESTUDOS DE CASO}

A Tabela 9, a seguir, apresenta um resumo dos principais resultados apresentados em cada caso, enfatizando o cumprimento dos valores orçados e prazos inicialmente definidos.

Tabela 9 - Resultados dos estudos de caso

\begin{tabular}{|c|c|c|c|c|c|c|c|}
\hline \multirow{2}{*}{$\begin{array}{l}\text { Estudo de } \\
\text { caso }\end{array}$} & \multirow{2}{*}{$\begin{array}{c}\text { Serviço } \\
\text { contratado }\end{array}$} & \multicolumn{2}{|c|}{ Venda (R\$) } & \multicolumn{2}{|c|}{ Prazo (meses) } & \multirow{2}{*}{$\begin{array}{l}\text { Variação } \\
\text { de Custo }\end{array}$} & \multirow{2}{*}{ Status } \\
\hline & & Previsto & Real & Previsto & Real & & \\
\hline $\mathrm{A} 1$ & Execução de obra & $918 \mathrm{mi}$ & $1,03 \mathrm{bi}$ & 28 & 31 & $65 \%$ maior & Finalizada \\
\hline $\mathrm{A} 2$ & Execução de obra & 1,4 bi & 1,75 bi & 36 & 70 & $25 \%$ maior* & Em andamento \\
\hline B1 & $\begin{array}{c}\text { Elaboração de } \\
\text { projeto e execução } \\
\text { de obra }\end{array}$ & $98 \mathrm{mi}$ & $89 \mathrm{mi}$ & 18 & 14 & $10 \%$ menor & Finalizada \\
\hline C1 & Execução de obra & $238 \mathrm{mi}$ & $392 \mathrm{mi}$ & 26 & 25 & $10 \%$ maior & Finalizada \\
\hline $\mathrm{C} 2$ & $\begin{array}{c}\text { Elaboração de } \\
\text { projeto, execução } \\
\text { de obra e } \\
\text { montagem } \\
\text { mecânica } \\
\end{array}$ & $540 \mathrm{mi}$ & $722 \mathrm{mi}$ & 22 & 20 & $37 \%$ maior & Finalizada \\
\hline D1 & Execução de obra & $154 \mathrm{mi}$ & $138 \mathrm{mi}$ & 18 & 16 & Redução** & Finalizada \\
\hline
\end{tabular}

*Limitado pela legislação brasileira

**O percentual de redução de custo não foi informado pelos entrevistados

Fonte: elaborado pelo autor

Pode-se perceber que, de acordo com a Tabela 9, na empresa A, o estudo de caso $A 1$ possui um acréscimo de venda com o cliente, no valor de 116 milhões de reais, e um acréscimo de prazo, de 3 meses. Além disso, os custos para execução do projeto evidenciaram aumento de, aproximadamente, $65 \%$ do valor inicialmente previsto. Isso ocasionou perda de resultados para o projeto e para o segmento de infraestrutura do grupo espanhol no Brasil. Os valores de custo de execução não foram informados na íntegra pelos entrevistados.

Os fatores principais que contribuíram para esse cenário foram: indefinições de projeto (design); ausência de uma equipe dedicada à gestão do processo de projetos, que poderia conduzir de maneira coordenada as definições necessárias; imprevistos não identificados na planilha inicial de riscos, que seriam reduzidos se os processos de riscos fossem implantados; mudanças de escopo por parte do cliente; e custos indiretos em função do acréscimo de prazo. 
Já o estudo de caso A2 apresenta um acréscimo de venda de 350 milhões e um acréscimo de prazo de 34 meses, podendo aumentar, tendo em vista que o projeto ainda está em andamento. Além disso, os custos para execução do projeto mostraram um aumento de, aproximadamente, $80 \%$ do valor inicialmente previsto, também impactando no resultado final do projeto. Da mesma forma que o caso anterior, os valores de custo não foram divulgados. Cabe ressaltar que o projeto apresentou receita negativa em vários meses de contrato, ou seja, os custos incorridos foram maiores que os valores faturados com o cliente.

Os fatores que contribuíram para o cenário identificado no estudo de caso A2 foram: atraso na liberação de áreas para execução dos serviços em função de desapropriações e licenças ambientais; embargos de áreas em função de passivos ambientais e comunidades indígenas; indefinições de projetos (design); mudanças de escopo; ausência de uma equipe dedicada à gestão do processo de projetos, que poderia conduzir de maneira coordenada as definições necessárias; imprevistos não identificados na planilha inicial de riscos, que seriam reduzidos se os processos de riscos fossem implantados; mobilização excessiva de recursos, ignorando os riscos de indisponibilidade de áreas liberadas; custos indiretos em função do acréscimo de prazo; ausência de um banco de dados para consulta de lições aprendidas, o que poderia ter orientado as equipes na condução do planejamento do empreendimento, considerando as paralisações por falta de liberação de áreas e por falta de projeto; e o compartilhamento de equipes de apoio entre projetos, o que impactou o tempo de resposta dessas equipes às demandas mais urgentes como compra de material, contratação de serviços específicos e contratação de mão de obra.

O caso A2, por se tratar de uma obra pública, teve limitação para reajuste em $25 \%$ do valor de venda, inicialmente contratado. Assim, em função das mudanças de escopo e das diferenças apontadas entre projeto básico e projeto executivo, parte do escopo contratado foi suprimido, causando conflito entre as partes.

A título de reparação aos acréscimos de custo incorridos nos casos A1 e A2, a empresa $A$ fez reivindicações junto aos clientes e recebeu parte dos valores solicitados, em ambos os casos. No entanto, os entrevistados apontaram que 
esses valores foram insuficientes para recuperar o equilibrio econômicofinanceiro dos contratos.

O estudo de caso B2 apresentou uma redução de venda de 9 milhões. Por se tratar de um empreendimento executado por uma empresa pertencente ao grupo, esse resultado foi interessante para os negócios. Os custos para execução do projeto também foram reduzidos em $10 \%$, sendo que os valores não foram divulgados pelos entrevistados. $O$ prazo contratual também foi reduzido em 4 meses.

Os fatores que contribuíram para redução do tempo de execução do projeto foram: processos bem definidos para a gestão do processo de projeto, o que auxiliou na condução das mudanças consideradas estratégicas para a execução dos serviços, além da antecipação a problemas relacionados a erros de projetos, falta de detalhamento de projeto e incompatibilidade; apoio da diretoria do grupo, como cliente do projeto; política de registro e compartilhamento de dados e lições aprendidas; e equipes dedicadas exclusivamente ao projeto.

A redução no valor de venda do contrato ocorreu em função de mudanças de projeto como, por exemplo, redução do número de estacas da fundação e utilização de peças pré-moldadas. Já a redução de custo para execução ocorreu em função da redução do prazo e consequente redução de custos indiretos, além de redução da contratação de mão de obra.

Os estudos de casos $\mathrm{C} 1$ e $\mathrm{C} 2$, da empresa $\mathrm{C}$, apresentaram acréscimos de venda de 154 milhões e 182 milhões, respectivamente. Já os custos para execução do projeto revelaram aumento de, aproximadamente, $10 \%$ para o caso C1 e 37\% para o caso C2. Os acréscimos de venda e custo ocorreram em função de indefinições de projeto (design); alterações entre projeto básico e projeto executivo; mudanças de escopo por parte do cliente; implantação de oportunidades identificadas na reunião inicial e na reunião de acompanhamento do empreendimento; e pleitos com o cliente.

No que se refere ao prazo contratual, os casos $\mathrm{C} 1$ e $\mathrm{C} 2$ denotaram redução de 1 mês e 2 meses, respectivamente. A redução no prazo contratual é uma meta 
gerencial para os empreendimentos da empresa C, pois exprimem redução de custos indiretos; redução de alguns custos diretos como locação de equipamentos; liberação de equipes para outros projetos; satisfação do cliente; e aumento da credibilidade para captação de novos projetos. Os fatores que contribuíram para a redução de prazo contratual foram: processos bem definidos para a gestão do processo de projeto, o que auxiliou na condução das mudanças consideradas estratégicas para a execução dos serviços, além da antecipação a problemas relacionados a erros de projetos, falta de detalhamento de projeto e incompatibilidade; um boa gestão de riscos, o que ajudou na redução do impacto de ocorrências negativas e potencializou as ocorrências positivas (oportunidades); política de registro e compartilhamento de dados e lições aprendidas; e equipes dedicadas exclusivamente ao projeto.

O estudo de caso $D 1$, inerente à empresa $D$, apresentou uma redução no valor de venda de 16 milhões e redução de prazo de 2 meses. Os custos, apesar de não serem divulgados, também foram reduzidos, conforme relatados pelos entrevistados. Isso gerou aumento dos resultados esperados para o projeto. Os fatores que contribuíram para a redução de custo e prazo foram: processos bem definidos para a gestão do processo de projeto, o que auxiliou na condução das mudanças consideradas estratégicas para a execução dos serviços, além da antecipação a problemas relacionados a erros de projetos, falta de detalhamento de projeto e incompatibilidade; condução coordenada para sanar as interferências de projeto (design) com as concessionárias; um boa gestão de riscos, o que ajudou na redução do impacto de ocorrências negativas e potencializou as ocorrências positivas (oportunidades); política de registro e compartilhamento de dados e lições aprendidas; e equipes dedicadas exclusivamente ao projeto.

Em resumo, os casos B1, C1, C2 e D1 foram bem sucedidos, no que se refere ao cumprimento do escopo contratado, prazo de execução e resultado financeiro esperado. Nos casos C1 e D2, apesar dos valores de venda e custo apresentarem aumento, os entrevistados afirmaram que os resultados foram mantidos ou obtiveram leve aumento em relação ao inicialmente esperado. $O$ caso $\mathrm{C} 2$ teve resultado positivo, porém menor do que o esperado inicialmente. 
Já os estudos de caso A1 e A2 apresentaram prejuízos financeiros, que impactaram de forma significativa o segmento de construção da empresa A no Brasil. Os gerentes dos projetos e diretores de obra buscaram recuperar os resultados por meio de pleitos junto aos clientes, mas afirmaram que esse processo é demorado, desgastante para ambas as partes e prejudica o bom relacionamento com o cliente, especialmente quando o objetivo da empresa é captar novos clientes e se manter no mercado de construção civil brasileiro. 0 Quadro 12 explicita uma síntese sobre os processos de gestão de riscos.

Quadro 12 - Síntese da gestão de riscos

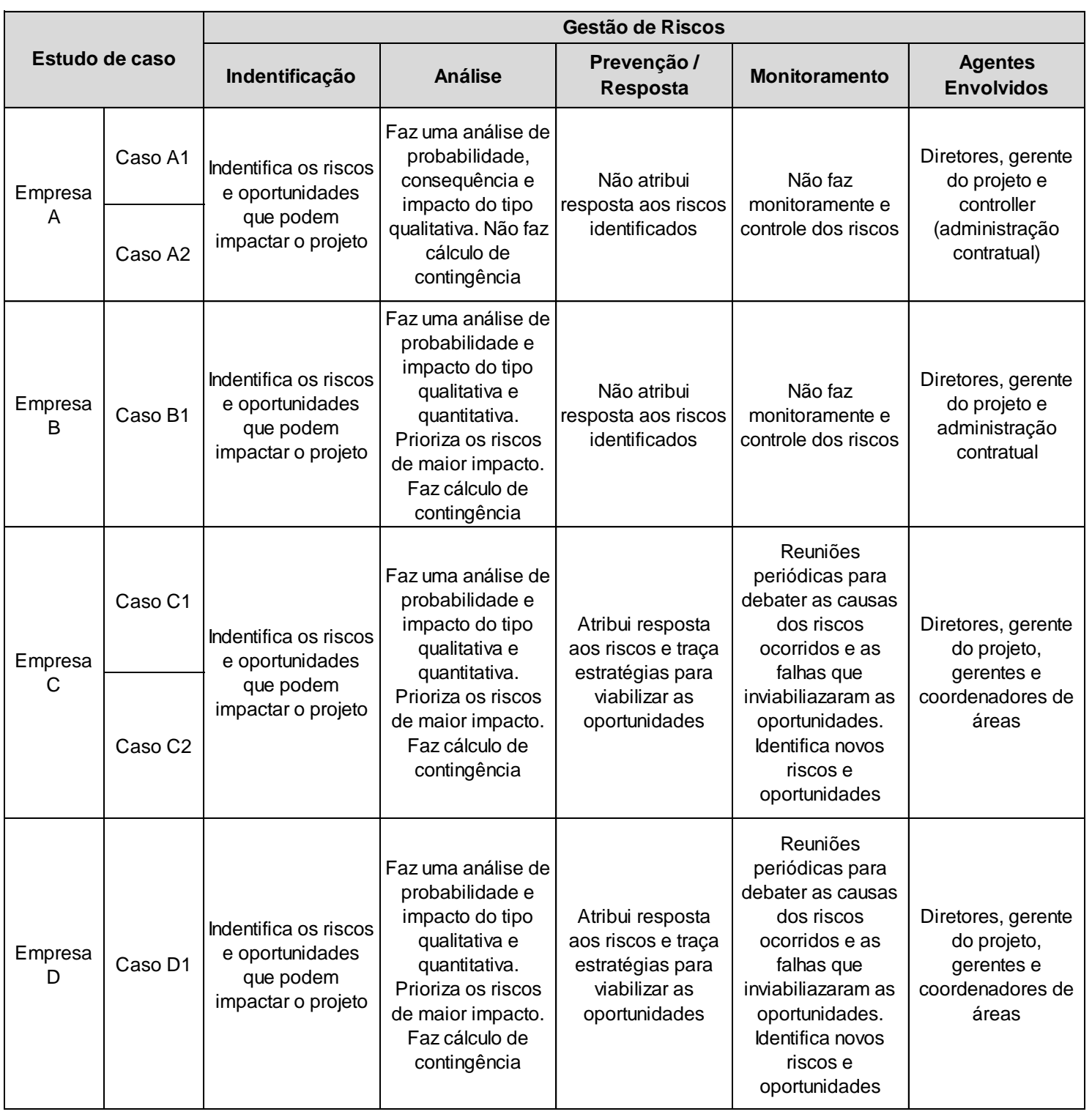

Fonte: dados da pesquisa 
Cabe destacar que os casos estudados das empresas A e B possuem processos incompletos para gestão de riscos, pois não apresentam respostas para os riscos identificados e não fazem o monitoramento e controle, cujo um dos objetivos e identificar novos riscos em diferentes etapas do projeto. Além disso, a participação e o conhecimento dos riscos ficam restritos à alta gerência e à diretoria do projeto.

O Quadro 13 evidencia uma síntese sobre a gestão do processo de projeto. A empresa A não possui uma equipe dedicada à coordenação de projetos, o que impossibilita uma análise crítica dos projetos e antecipação de dados para a produção.

Quadro 13 - Síntese da gestão do processo de projeto

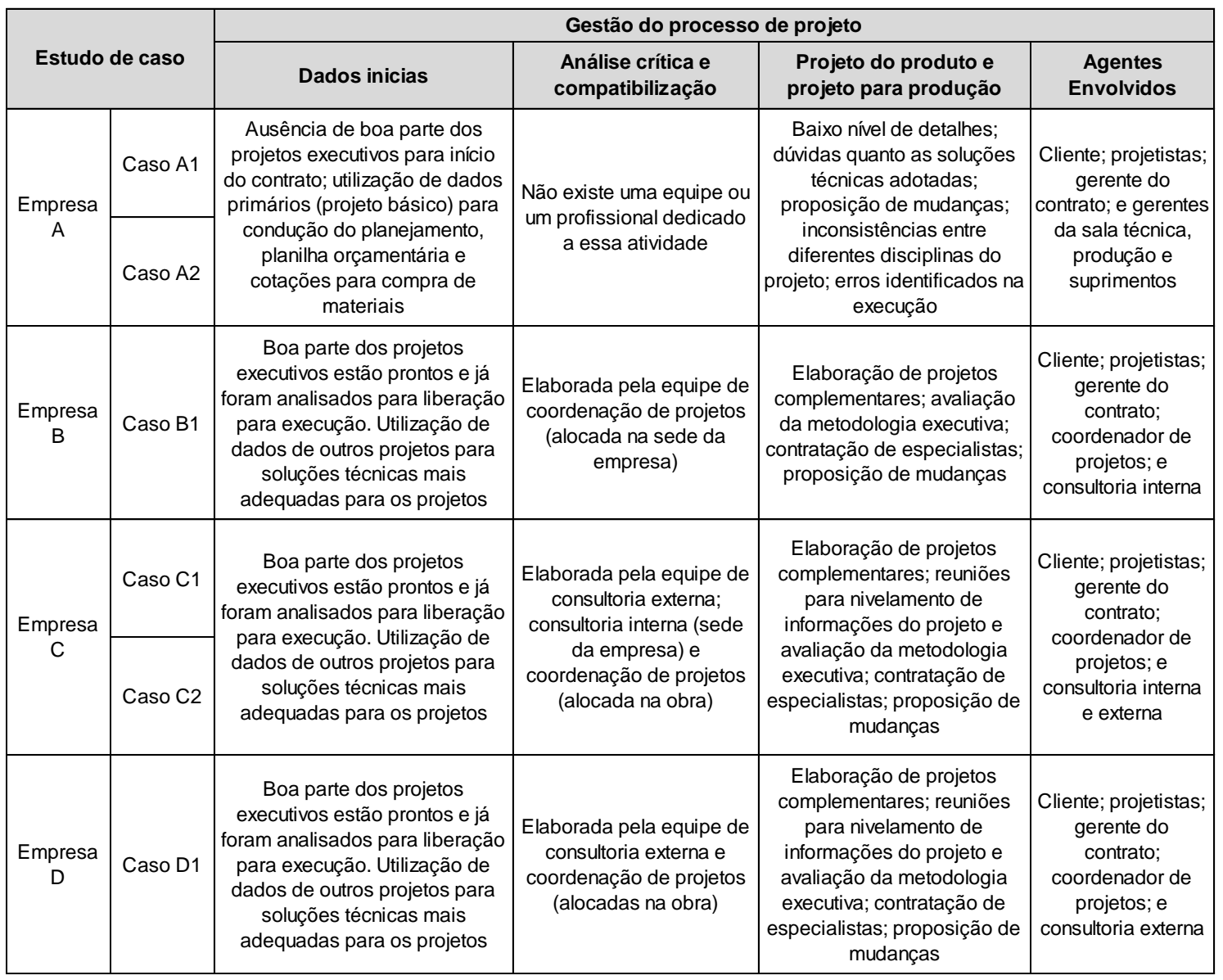

Fonte: dados da pesquisa

De acordo com Oliveira, Fabrício e Melhado (2004) o projeto deve permitir a construtibilidade do empreendimento, reduzindo olead time de execução e os 
custos finais do empreendimento. As empresas $B, C$ e $D$ praticam a análise crítica, a fim de melhorar a qualidade dos projetos para produção.

O Quadro 14 expõe uma síntese sobre os processos de gestão da informação e do conhecimento, contendo as principais observações sobre as condições de acesso às informações e à geração de conhecimento nos projetos analisados.

Quadro 14 - Síntese da gestão da informação e do conhecimento

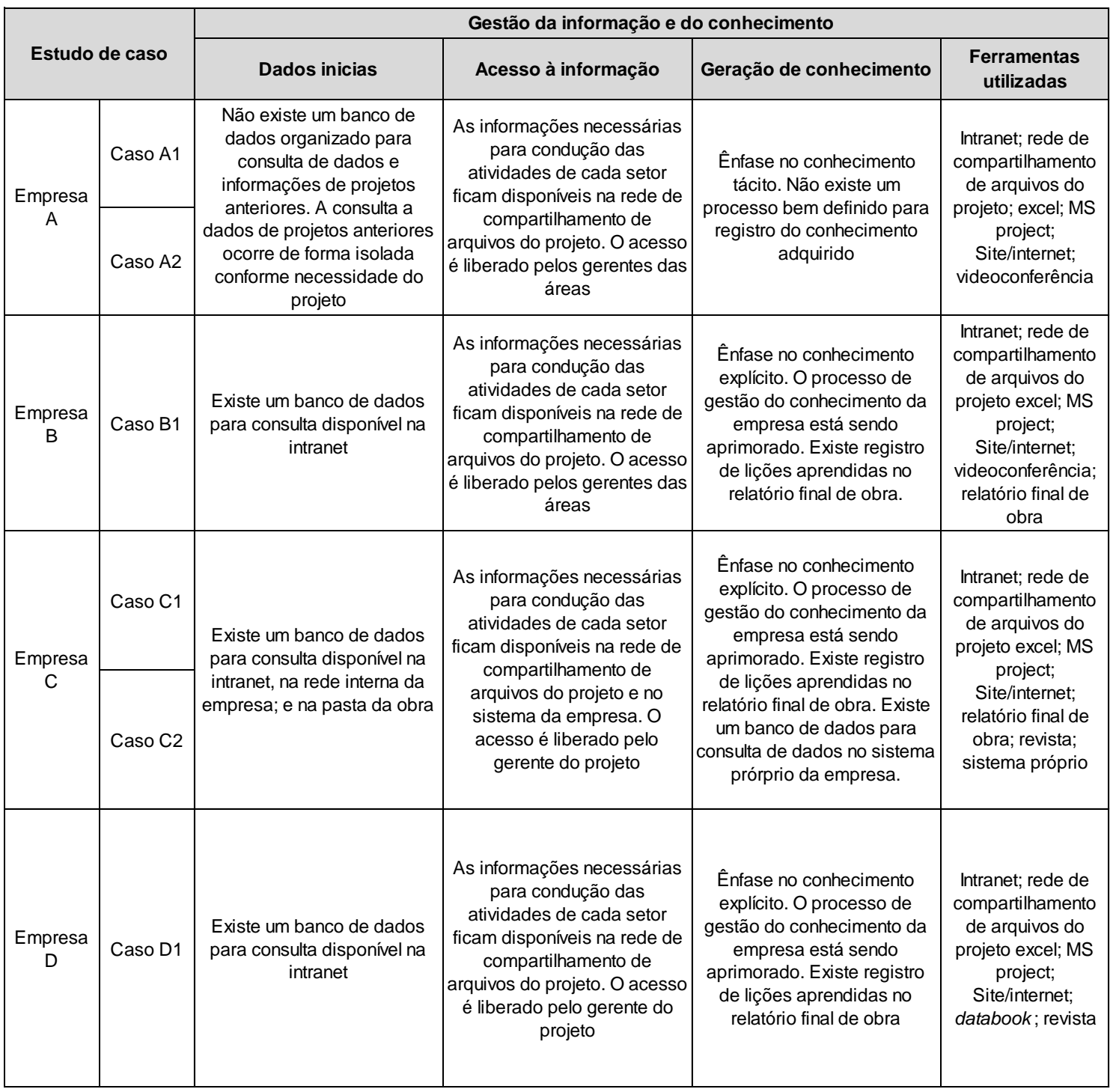

Fonte: dados da pesquisa

A empresa A possui dificuldade em transformar o conhecimento tácito em explícito, e os dados que são registrados não são bem organizados para 
consultas futuras. Isso dificulta o acesso à informação e impacta de forma negativa os demais processos de gestão.

O Quadro 15 apresenta uma síntese sobre os processos de gestão da comunicação. Nenhum dos casos analisados possui processos formais para estabelecer a comunicação interna entre os envolvidos no projeto. Já a comunicação externa é formalizada por meio de documentos, a fim de garantir os cumprimentos legais e contratuais.

Quadro 15 - Síntese da gestão da comunicação

\begin{tabular}{|c|c|c|c|c|c|}
\hline \multirow{2}{*}{\multicolumn{2}{|c|}{ Estudo de caso }} & \multicolumn{4}{|c|}{ Gestão da comunicação } \\
\hline & & Interna & Externa & Ferramentas utilizadas & Barreiras identificadas \\
\hline $\begin{array}{c}\text { Empresa } \\
\text { A }\end{array}$ & Caso A1 & $\begin{array}{l}\text { Não existe processo } \\
\text { formal. O meio de } \\
\text { comunicação entre as } \\
\text { equipes são os gerentes } \\
\text { e coordenadores }\end{array}$ & $\begin{array}{l}\text { Processo formal } \\
\text { conduzido pelo setor de } \\
\text { controller. }\end{array}$ & $\begin{array}{l}\text { Interna: Reuniões gerais } \\
\text { e setoriais no projeto. } \\
\text { Externa: cartas, e-mails, } \\
\text { atas de reuniões, dentre } \\
\text { outros documentos }\end{array}$ & $\begin{array}{l}\text { Falta de nivelamento } \\
\text { das informações; conflito } \\
\text { de informações; cultura } \\
\text { diferente; resistência por } \\
\text { parte do cliente }\end{array}$ \\
\hline $\begin{array}{c}\text { Empresa } \\
\text { B }\end{array}$ & Caso B1 & $\begin{array}{l}\text { Não existe processo } \\
\text { formal. O meio de } \\
\text { comunicação entre as } \\
\text { equipes são os gerentes } \\
\text { e coordenadores }\end{array}$ & $\begin{array}{l}\text { Processo formal } \\
\text { conduzido pelo setor de } \\
\text { administração } \\
\text { contratual. }\end{array}$ & $\begin{array}{l}\text { Interna: Reuniões gerais } \\
\text { e setoriais no projeto. } \\
\text { Externa: cartas, e-mails, } \\
\text { atas de reuniões, dentre } \\
\text { outros documentos }\end{array}$ & $\begin{array}{c}\text { Falta de nivelamento } \\
\text { das informações; cultura } \\
\text { diferente; }\end{array}$ \\
\hline $\begin{array}{c}\text { Empresa } \\
\text { C }\end{array}$ & Caso C2 & $\begin{array}{c}\text { Não existe processo } \\
\text { formal. O meio de } \\
\text { comunicação entre as } \\
\text { equipes são os gerentes } \\
\text { e coordenadores }\end{array}$ & $\begin{array}{c}\text { Processo formal } \\
\text { conduzido pelo setor de } \\
\text { engenharia. }\end{array}$ & $\begin{array}{c}\text { Interna: Reuniões gerais } \\
\text { e setoriais no projeto. } \\
\text { Painéis de gestão à } \\
\text { vista. } \\
\text { Externa: cartas, e-mails, } \\
\text { atas de reuniões, dentre } \\
\text { outros documentos }\end{array}$ & $\begin{array}{l}\text { Falta de nivelamento } \\
\text { das informações; } \\
\text { segregação das } \\
\text { informações; resistência } \\
\text { por parte do cliente }\end{array}$ \\
\hline $\begin{array}{c}\text { Empresa } \\
\text { D }\end{array}$ & Caso D1 & $\begin{array}{l}\text { Não existe processo } \\
\text { formal. O meio de } \\
\text { comunicação entre as } \\
\text { equipes são os gerentes } \\
\text { e coordenadores }\end{array}$ & $\begin{array}{c}\text { Processo formal } \\
\text { conduzido pelo setor de } \\
\text { engenharia }\end{array}$ & $\begin{array}{c}\text { Interna: Reuniões gerais } \\
\text { e setoriais no projeto. } \\
\text { Painéis de gestão à } \\
\text { vista. } \\
\text { Externa: cartas, e-mails, } \\
\text { atas de reuniões, dentre } \\
\text { outros documentos }\end{array}$ & $\begin{array}{c}\text { Falta de nivelamento } \\
\text { das informações; conflito } \\
\text { de informações; } \\
\text { resistência por parte do } \\
\text { cliente }\end{array}$ \\
\hline
\end{tabular}

Fonte: dados da pesquisa

Todos os casos possuem como barreira a segregação das informações, sendo que, nos casos da empresa $A$, as informações são duplicadas entre os setores e equipes. As empresas A e B dispõem da barreira "diferença cultural" como fator 
importante no estabelecimento de uma boa comunicação, especialmente para o caso da empresa $A$, no que se refere à implantação dos processos de gestão. $A$ empresa $A$ também porta a resistência por parte do cliente para tratar com gerentes de outra nacionalidade. Nesse caso, o cliente alega dificuldade de compreensão do dialeto praticado.

A partir dos conceitos de gestão destacados na revisão da literatura e da análise dos processos adotados pelas empresas nos casos estudados, foi possível identificar aspectos que necessitam atenção, no que se refere às práticas adotadas e sua relação com o sucesso dos projetos.

Em todos os casos estudados, foi cumprida a etapa de identificação de riscos. Essa identificação ocorreu de maneiras distintas. Um problema levantando em alguns casos foi a falta de conhecimento das equipes de projeto quanto à análise de riscos, bem como o cumprimento das demais etapas do processo de gestão de riscos. Isso, de acordo com os entrevistados, apresentou falhas, já destacadas neste trabalho, que impactaram no bom andamento das atividades.

Um problema apontado por todos os entrevistados foi a falta de detalhes e informações dos projetos básicos e a falta de qualidade e detalhamento dos projetos executivos. Para os casos em que a elaboração dos projetos executivos eram de responsabilidade das empresas contratadas, havia um maior empenho em sanar esses problemas. Para os casos em que o projeto executivo era de responsabilidade do cliente, foi necessário administrar entregas parciais, bem como atrasos no envio dos projetos para execução.

A consulta a dados e informações de outros projetos, para iniciar a análise de riscos, definir métodos construtivos e decidir a contratação de serviços específicos, se mostrou bastante relevante para os casos que faziam o armazenamento desses dados. Para os casos que não registravam informações dos projetos, houve consenso entre os entrevistados quanto à importância da implantação desse processo.

De maneira geral, os entrevistados se mostraram satisfeitos com os processos de comunicação externa, que é formalizado por meio de documentos registrados 
entre as partes. No entanto, manifestaram insatisfação quanto ao alto grau de informalidade da comunicação interna entre equipes.

A partir do contexto deste estudo, e buscando extrair as melhores práticas adotadas em cada caso, aliado com os processos de gestão apontados na literatura, são propostas nove diretrizes que conduzem para o sucesso dos projetos:

1 diretriz: identificados os riscos e oportunidades dos projetos, deve-se proceder com as análises de probabilidade, impacto e atribuição de valor para a ocorrência, a fim de obter os valores devidos para a contingência e evitar desvios de custo;

2a diretriz: deve-se dar prioridade à atribuição de respostas aos riscos e oportunidades, bem como ao processo de monitoramento e controle, para garantir a correta tratativa para as ocorrências negativas, potencializar as ocorrências positivas e identificar novos riscos e oportunidades ao longo da execução do projeto;

3ª diretriz: a divulgação da matriz de riscos deve envolver todos os gerentes e coordenadores de equipes do projeto, de modo a assegurar a conveniente divulgação da informação e a participação mais ativa na etapa de monitoramento e controle;

4ª diretriz: a composição das equipes deve contemplar uma de coordenação de projetos (design) bem dimensionada e qualificada, com o propósito de garantir que a gestão do processo de projeto seja seguida;

5ํㅗㄹ diretriz: a equipe de coordenação de projetos precisa estar atenta à qualidade das informações do projeto (design), por meio de análise crítica, compatibilização e análise da construtibilidade, com o intuito de reduzir erros e atestar um bom projeto para produção;

6⿳亠口冋 diretriz: identificada a necessidade de revisor externo para a análise dos projetos (design), deve-se elaborar um cronograma para cumprimento de etapas de revisão, objetivando evitar atrasos na liberação dos projetos para construção; 
$7^{\text {a }}$ diretriz: durante a execução e, principalmente, no final do projeto devem-se registrar informações como tecnologias adotadas; índices de produtividade; e principais custos negociados que serviram como base para a tomada de decisão das equipes, além das lições aprendidas. Isso é preciso porque o segmento de construção apresenta alta rotatividade de profissionais e a ausência de registro significa perda de conhecimento adquirido;

8 diretriz: antes de iniciar um novo projeto, o responsável (gerente do projeto), deve consultar dados de outros projetos, com a finalidade de reduzir as incertezas quanto aos riscos envolvidos, contemplar as oportunidades e avaliar os métodos construtivos a partir das tecnologias adotadas. Para isso, é necessário que a empresa disponha de um banco de dados organizado;

9a diretriz: o responsável pelo projeto deve estabelecer uma comunicação formal e eficaz entre as diferentes equipes, de modo a diminuir a sobreposição de atividades e garantir o alinhamento das informações no tempo e qualidade necessárias.

Essas diretrizes visam atender as necessidades dos projetos estudados, melhorar os processos existentes e incentivar a implantação de novos processos de gestão. 


\section{CONSIDERAÇÕES FINAIS E RECOMENDAÇÕES}

Após análise da literatura verificou-se que o processo de internacionalização de empresas representa um novo desafio à gestão de projetos, sejam eles relacionados à implantação dos processos ou a mudanças organizacionais, existe a necessidade de gerenciar equipes com pensamentos multiculturais. Essa análise também evidenciou a escassez de estudos que abordam o fenômeno de internacionalização de empresas para o mercado de construção civil brasileiro, especialmente no enfoque da gestão de projetos. Assim, buscouse compreender como a gestão de projetos influencia o sucesso dos empreendimentos de infraestrutura executados por empresas brasileiras e empresas multinacionais atuantes no mercado de construção civil brasileiro.

A fim de alcançar o objetivo proposto, empreendeu-se um estudo de campo com enfoque qualitativo de caráter comparativo junto a 4 empresa e 6 projetos, sendo uma empresa de origem espanhola, uma de origem argentina e duas de origem brasileira. Os dados foram colhidos basicamente junto aos gerentes dos projetos, por meio de entrevistas individuais subsidiadas por um roteiro de perguntas abertas.

Em linhas gerais, e corroborando com a literatura, ainda é grande a associação do sucesso dos projetos ao cumprimento da tripla restrição custo, tempo e escopo do projeto. Para os casos das empresas multinacionais, outro fator importante para o sucesso dos projetos é a satisfação dos clientes, uma vez que um dos objetos das empresas é ampliar o campo de atuação no Brasil.

Do ponto de vista da implantação dos processos de gestão, foram observadas falhas em alguns casos; além da falta de conhecimento dos envolvidos quanto aos processos adotados pelas empresas e da falta de maturidade gerencial para assumir uma postura mais enérgica, visando a implantação ou melhoria dos processos. Como consequência, alguns casos apresentaram atrasos e prejuízos econômicos; e outros redução no resultado esperado.

$\mathrm{Na}$ visão dos gerentes entrevistados, grande parte dos problemas que influenciaram no sucesso dos projetos foi de responsabilidade dos clientes. No 
entanto, todos os fatores associados aos clientes representavam riscos passíveis de serem controlados, sendo que a falha foi constatada na falta de resposta para esses riscos e na falta de monitoramento e controle para retroalimentar o processo.

Outras dificuldades reportadas pelos entrevistados se referem à gestão do processo de projetos que, em alguns casos, era inexistente. A falta de uma equipe dedicada à gestão dos projetos (design) e à interface cliente-projetistaobra ocasionou erros e atrasos que impactaram, de forma significativa, os resultados dos empreendimentos estudados. Além disso, a literatura reforça cada vez mais a importância do coordenador de projetos como liderança dessa equipe, a fim de garantir que as melhores soluções técnicas e gerenciais sejam alcançadas, visando $\mathrm{o}$ atendimento às necessidades e objetivos das partes interessadas.

No que se refere à gestão da informação e do conhecimento, os entrevistados reconheceram a importância do registro de dados dos projetos, especialmente para consultas futuras. Em alguns casos, ficou evidente a perda de tempo buscando informações que deveriam estar armazenadas, mas que foram perdidas com o encerramento dos projetos e rotatividade das equipes. Um ponto de atenção se refere à necessidade de melhoria dos processos para registro $\mathrm{e}$ disseminação da informação e conhecimento entre as equipes, que deve ser facilitado, visando a integração do conhecimento.

Cabe ressaltar que uma atividade comum em empresas de construção é buscar informações de projetos anteriores e conhecimentos adquiridos pelas equipes desses projetos. Esses dados auxiliam a condução de vários processos como, por exemplo: os índices de custo e produtividade de projetos anteriores auxiliam a elaboração de orçamentos e planejamentos mais precisos; registro de lições aprendidas reduzem as incertezas dos projetos e auxiliam os processos de identificação de riscos e oportunidades, entre outros.

Em todos os casos analisados, a gestão da comunicação se mostrou eficaz para os agentes externos e ineficaz para os agentes internos do projeto. A comunicação interna era informal, o que gerou duplicidade de atividades; erros 
na aquisição de materiais e contratação de serviços; dentre outros problemas. Conforme visto na literatura, a falta de informação em tempo real é uma característica marcante na indústria da construção civil. Esse fato aumenta a necessidade de implantação de processos bem definidos, visando uma comunicação eficaz entre as equipes. No caso C2 houve a necessidade de contratação de uma equipe de consultoria para auxiliar a gestão da comunicação do projeto. Identificar o problema e buscar uma solução eficaz demonstra maturidade gerencial e gera um bom exemplo para outros projetos.

Como recomendação para as empresas estudadas e para outras empresas de construção civil, sugere-se adotar as diretrizes propostas neste trabalho. Essas diretrizes foram baseadas na análise dos resultados dos estudos de caso e representam uma síntese dos processos bem sucedidos aliados às recomendações da literatura.

Também é importante ressaltar duas limitações. A primeira refere-se aos processos de gestão escolhidos. Certamente outros processos como gestão de tempo, custo, stakeholders, afetam o sucesso de projetos executados por empresas internacionais que atuam no Brasil. No entanto, os processos analisados neste estudo foram considerados os mais relevantes, após revisão da literatura. A segunda restrição diz respeito à quantidade de casos estudados. Por se tratar de um número relativamente pequeno não se pode generalizar os resultados obtidos.

Espera-se que este trabalho incentive o desenvolvimento de novas pesquisas sobre o tema. Como exemplos, sugerem-se algumas possibilidades:

- desenvolvimento de estudos comparativos das práticas de gestão de projetos adotadas nos projetos executados no Brasil e executados nos países e origem;

- caracterização do perfil e das atribuições dos profissionais de gestão atuantes em projetos internacionais; e

- o modo como as empresas de construção civil podem adaptar os processos de gestão da literatura para as necessidades dos seus projetos globais. 


\section{REFERÊNCIAS BIBLIOGRÁFICAS}

A.T. KEARNEY. Brasil cai nove posições no ranking de preferência dos investidores estrangeiros da A.T. Kearney. Disponível em www.tramaweb.com.br/imprensa. Acesso em: 30 mai. 2018

ALMEIDA, N. O.; FARIAS FILHO, J. R. Definindo sucesso em projetos. XXX encontro nacional de engenharia de produção. São Carlos, SP, Brasil, 12 a15 de outubro de 2010

ANBARI F. T., CARAYANNISB E. G., VOETSCH R. J. Post-project reviews as a key. Project management competence Technovation, v. 28, n. 10, p. 633-643. doi:10.1016/j.technovation.2007.12.001, 2008.

BEST, R., LANGSTON, C. Evaluation of construction contractor performance: A critical analysis of some recent research. Construction Management and Economics 24(4), pp. 439-445, 2006

BORGES, J. G.; CARVALHO, M. M. Critérios de sucesso em projetos: um estudo exploratório considerando a interferência das variáveis tipologia de projetos e stakeholders. Production, v. 25, n. 1, p. 232-253, jan./mar. 2015 doi: http://dx.doi.org/10.1590/S0103-65132014005000019

BREITBACH, A.C.M. Indústria da Construção Civil: a retomada. Revista Indicadores, 2009.

CARRILLO et al. (2013) When will we learn? Improving lessons learned practice in construction. International Journal of Project Management. DOI: 10.1016/j.ijproman.2012.10.005

CARRILLO, P.; CHINOWSKY, P. (2006). "Exploiting knowledge management: The engineering and construction perspective." Journal of Management in Engineering, 22(1), 2-10.

CARVALHO, M. M.; RABECHINI JR., R. Fundamentos em gestão de projetos: construindo competências para gerenciar projetos. 4. ed. São Paulo: Atlas, 2015.

CARVALHO, M.M., FLEURY, A., LOPES, A.P. An overview of the literature on technology roadmapping (TRM): contributions and trends. Technol. Forecast. Soc. Change 80, 1418e1437, 2013

CBIC - CÂMARA BRASILEIRA DA INDÚSTRIA DA CONSTRUÇÃO. Projetos. Disponível em https://cbic.org.br/. Acesso em: 25/05/2018.

CHAN, E.H.W., TSE, R.Y.C. Cultural Considerations in International Construction Contracts. Journal of Construction Engineering and Management 129(4), pp. 375-381, 2003. 
CHAVES, L. E., et al. Gerenciamento da comunicação em projetos. Rio de Janeiro: Editora FGV, 2006.

CHEN, C., MESSNER, J.I. Entry mode taxonomy for international construction markets. Journal of Management in Engineering 25(1), pp. 3-11, 2009

CHEN, Y.; KAMARA, J. M. "A framework for using mobile computing for information management on construction sites". Automation in Construction, v. 20, n. 7 , p. $776-788$, nov. 2011.

CRAWFORD, L., POLLACK, J., \& ENGLAND, D. (2007). How standard are standards: an examination of language emphasis in project management standards. Project Management Journal, 38(3), p. 6-21.

CUERVO, J. C.; LOW, S. P. (2003). "Ownership advantages/disadvantages of Singapore transnational construction corporations." Constr. Manage. Econ., 21(1), 81-94.

DENG, X., LOW, S.P., LI, Q., ZHAO, X. Developing competitive advantages in political risk management for international construction enterprises. Journal of Construction Engineering and Management 140(9),04014040, 2014

DIKMEN, I.;BIRGONUL, M.T.;HAN, S. Using fuzzy risk assessment to rate cost overrun risk in international construction projects. International Journal of Project Management, 2007.

DUTRA, H. Construção civil no Brasil: situação atual e projeções para 2018. Disponível em https://www.sienge.com.br/blog/construcao-civil-no-brasil/. Acesso em 30 de maio de 2018.

DVIR, D., LIPOVETSKY, S., SHENHAR, A., TISHLER, A. In search of project classification: A non-universal approach to project success factors. Research Policy 27(9), pp. 915-935, 1998.

FARIA, A. F.; PINTO, A.C.A.; RIBEIRO, M.N.; CARDOSO, T.S.; RIBEIRO, J.P.C. Processo de desenvolvimento de novos produtos: uma experiência didática. Rio de Janeiro: XXVIII Encontro Nacional de Engenharia de Produção (ENEGEP), 2008.

FLANAGAN, R. (1994). "The features of successful construction companies in the international construction market." Proc., A.J. Etkin Int. Seminar on Strategic Planning in Construction Companies, A. Warzawski and R. Navon, eds., Israel Technion—Isarel Institute of Technology, Haifa, Israel.

FLEURY, M. T. L.; FLEURY, A. O desenvolvimento das multinacionais brasileiras no cenário global. GVEXECUTIVO • V 15 • N 1 • JAN/JUN 2016 
FLORIANI, D. E. \& FLEURY, M. T. (2012). O Efeito do Grau de Internacionalização nas Competências Internacionais e no Desempenho Financeiro da PME Brasileira. Revista de Administração Contemporânea RAC, Rio de Janeiro, v. 16, n. 3, art. 6, pp. 438- 458.

FORTUNE, J., WHITE, D. Framing of project critical success factors by a systems model. International Journal of Project Management 24(1), pp. 53-65, 2006

FOX, S. Effective communication: stone age to e-comm. Proccedings of the Project Management Institute Annual Seminars \& Symposium, USA: 2001.

GHEMAWAT, P. (2007). Redefining global strategy: crossing borders in a world where differences still matter. Harvard Business Press.

GUNHAN, S.; ARDITI, D. (2005a). Factors Affecting International Construction. Journal of Construction Engineering and Management, Vol. 131, p. 273-282.

GUNHAN, S.; ARDITI, D. (2005b). International Expansion Decision for Construction Companies. Journal of Construction Engineering and Management, Vol. 131, p. 928-937.

HAN, S. H. et. al. Causes of Bad Profit in Overseas Construction Projects. Journal of construction engineering and management, page 932, 2007.

HASTAK, M.;SHAKED, A. ICRAM-1:Model for International Construction Risk. Assessment. Journal of Management in Engineering, v.16,n.1, Jan-Fev 2000.

$\mathrm{HOMRICH}, \mathrm{A}$. S. et al. The circular economy umbrella: Trends and gaps on integrating pathways. Journal of Cleaner Production. Volume 175, 20 February 2018, Pages 525-543.

Hope, J. (2000). Competindo na terceira onda: os 10 mandamentos da era da informação. Rio de Janeiro: Campus.

HOWELL, G.; KOSKELA, L. "Reforming project management: the role of lean construction." In: ANNUAL CONFERENCE OF THE INTERNATIONAL GROUP OF LEAN CONSTRUCTION, 8., Brighton, 2000. Anais... Brighton, 2000

HWANG, B., \& LIM, E. J. Critical success factors for key project players and objectives: case study of singapore. Journal of Construction Engineering and Management, 139(2), 204-215, 2013.

JAVERNICK-WILL, A. (2013). "Local Embeddedness and Knowledge Management Strategies for Project-Based Multi-National Firms". Engineering Management Journal 25(3): 16-26. DOl: 10.1080/10429247.2013.11431979. 
JAVERNICK-WILL, A. N. (2009). "Organizational learning during internationalization: acquiring local institutional knowledge." Construction Management and Economics, 27(8), 783-797.

JAVERNICK-WILL, A. N., AND SCOTT, W. R. (2010). "Who Needs to Know What? Institutional Knowledge and Global Projects." Journal of Construction Engineering and Management, 136(5), 546.

JAVERNICK-WILL; HARTMANN, T. (2011). "Knowledge management in global environments." Organization Management in Construction, 23.

JIN, Z.; DENG, F; LI, H.; SKITMORE, M. "Practical Framework for Measuring Performance of International Construction Firms". Journal of Construction Engineering and Management, 1154 -1167 ASCE, Setembro, 2013.

JORDAO et al. Fatores críticos na gestão de projetos: um estudo de caso numa grande empresa latino-americana de classe mundial. Gest. Prod., São Carlos, v. 22, n. 2, p. 280-294, 2015.

KADRY, M., OSMAN, H., GEORGY, M. Causes of Construction Delays in Countries with High Geopolitical Risks. Journal of Construction Engineering and Management 143(2),04016095, 2017.

KERZNER, H. Gestão de Projetos - As Melhores Práticas. Bookman. 3ª Ed. 2016.

KERZNER, H. R. (2002). "Strategic planning for project management using a project management maturity model". John Wiley \& Sons.

KIM, C.; LIM, H.; KIM, H. "Mobile computing platform for construction site management." In: Proceedings of 28th International Symposium on Automation and Robotics in Construction. Seoul, Korea. 2011.

KPMG. Multinacionais brasileiras: a rota dos investimentos brasileiros no exterior. 2006.

KULULANGA G.; KUOTCHA W. Measuring project risk management process for construction contractors with statement indicators linked to numerical scores. Department of Civil Engineering, University of Malawi, Chichiri, Malawi. Engineering, Construction and Architectural Management Vol. 17 No. 4, 2010 pp. 336-351.

LING, F. Y. Y., AND KWOK, D. H. Y. (2007). "Enablers for Singapore contractors to internationalize construction services." Constr. Manage. Econ., 25(3), 267-275.

LING, F., IBBS, C. W., AND CUERVO, J. C. (2005). "Entry and business strategies used by international architectural, engineering and construction firms in China." Constr. Manage. Econ., 23(5), 509-520. 
LOW, S. P., AND JIANG, H. (2003). "Internationalization of Chinese construction enterprises.” J. Constr. Eng. Manage., 129(6), 589-598.

LOW, S. P., AND JIANG, H. (2004). "Estimation of international construction performance: Analysis at the country level." Constr. Manage. Econ., 22(3), 277-289.

LOW, W.W., ABDUL-RAHMAN, H., ZAKARIA, N. The impact of organizational culture on international bidding decisions: Malaysia context. International Journal of Project Management 33(4), pp. 917-931, 2015.

LOWE D. Commercial Management: Theory and Practice. Wiley-Blackwell. 2013.

MAHENDRA, P.A.; PITRODA, J.R.; BHAVSAR, J.J. A Study of Risk Management Techniques for Construction Projects in Developing Countries. International Journal of Innovative Tecnology and Exploring Engineering (IJITEE). ISSN: 2278-3075, Volume-3, Outubro de 2013.

MATOS, E. L. de; VIANA, L. S.; OLIVEIRA, V. L. S. de. Internacionalização das empresas brasileiras: como potencializar as oportunidades e enfrentar desafios. In: C@LEA - Cadernos de Aulas do LEA, n. 4, p. 16-29, llhéus - BA, nov. 2015.

MATTOS, AI.D., Planejamento e controle de obras. São Paulo: Pini, 2010.

MDIC. Ministério do Desenvolvimento, Indústria e Comércio Exterior. Disponível em: <http://www.mdic.gov.br/sitio/>.

MELHADO, S. B. Coordenação de projetos de edificações. São Paulo: O Nome da Rosa, 2005.

MELHADO, S. B. Qualidade do projeto na construção de edifícios: aplicação ao caso das empresas de incorporação e construção. São Paulo: EPUSP, 1994 (Tese de Doutorado).

MELO, D. R. A. A importância da tecnologia da informação nas estratégias das organizações contemporâneas: breve revisão de literatura. V CONVIBRA - Congresso Virtual Brasileiro de Administração. 2008.

MUTTI, C. N. The drivers of Brazillian contractors' competitiveness in the international market. 2004. $335 \mathrm{f}$. Tese (Doutorado) - School Of Construction Management and Engineering, United Kingdom, 2004.

MUTTI, C. N.; ARAÚJO, H. N.; FLANAGAN, R. Aspectos estratégicos da internacionalização de grandes construtoras brasileiras: vantagens e obstáculos. In: ENTAC, XI, 2006, Florianópolis. p. 2496 - 2505. 
NAKAGAWA, Y. "Real time performance information system". In: ANNUAL CONFERENCE OF THE INTERNATIONAL GROUP OF LEAN COSNTRUCTION, 14. Santiago, 2006. Anais... Santiago, 2006.

NASCIMENTO, C. E.; FORMOSO, C. T. Método para avaliar o projeto do ponto de vista da produção. In: VII ENCONTRO NACIONAL DE TECNOLOGIA DO AMBIENTE CONSTRUÍDO - QUALIDADE NO PROCESSO CONSTRUTIVO. Florianópolis, 1998.

NASCIMENTO, L. A.; SANTOS, E. T. A indústria da construção na era da informação. Ambiente Construído, n. 11, p. 69-81, 2008.

NONAKA, I.; TAKEUCHI, H. Criação de conhecimento na empresa: como as empresas japonesas geram a dinâmica da inovação. $2^{a}$ ed. Rio de Janeiro: Campus, 1997.

NONAKA, I.; TAKEUCHI, H. The knowledge-crating company: How Japanese companies create the dynamics of innovation. New York: Oxford University Press, 1995.

OFORI, D. F. Project management practices and critical success factors a developing country perspective. International Journal of Business and Management, 8(21), 14-31, 2013.

OFORI, G. (2003). "Frameworks for analysing international construction." Constr. Manage. Econ., 21(4), 379-391.

OIVEIRA, O. J.; MELHADO, S. B., Proposta de um modelo de gestão para pequenas empresas de projeto de edifícios. Gestão \& Tecnologia de Projetos. Vol. 3, no 2, Novembro de 2008.

OLIVEIRA, O. J.; FABRICIO, M. M.; MELHADO, S. B. "Improvement of the design process in the building construction". CIB WORLD BUILDING CONGRESS 2004. Proceedings... Toronto, Canada: 2004.

OLOUFA, A. A.; HOSNI, Y. A.; FAYEZ, M.; AXELSSON, P. (2004). "Using DSM for modeling information flow in construction design projects", Civil Engineering and Environmental Systems, 21:2, 105-125, DOI: 10.1080/10286600310001638474.

ORR, R. J., AND SCOTT, W. R. (2008). "Institutional exceptions on global projects: a process model." Journal of International Business Studies, 39(4), 562-588.

ÖZTAŞ, A., \& ÖKMEN, Ö. (2005). "Judgmental risk analysis process development in construction projects". Building and Environment, 40(9), 1244-1254. 
PARIS, S. , Cross, R. , \& Davenport, T.H. (2006). Strategies for preventing a knowledge-loss crisis. MIT Sloan Management Review, 47(4), 31-38.

PERROTTI, E.; VASCONCELLOS, E. P. G.. Estrutura organizacional e gestão do conhecimento. Brasilia, DF: Anais do 29‥ Enanpad, 2005.

PETERSEN, B.; PEDERSEN, T. (2002). "Coping with liability of foreignness: Different learning engagements of entrant firms." Journal of International Management, 8(3), 339-350.

PMI, PROJECT MANAGEMENT INSTITUTE. The Standard for Portfolio Management. 3. ed. Pensilvânia: PMI Publications, 2013.

PMI, PROJECT MANAGEMENT INSTITUTE. The Standard for Portfolio Management. 3. ed. Pensilvânia: PMI Publications, 2014.

PMISURVEY. (2014). PMSURVEY.ORG.Brasil (No. 2013 Edition). Project Management Institute. Recuperado de HTTP://www.pmsurvey.org/.

PONCHIROLLI, O.; FIALHO, F. A. P. Gestão estratégica do conhecimento como parte da estratégia empresarial. Rev. FAE, Curitiba, v.8, n.1, p.127-138, jan.jun. 2005

ROBINSON, H. S., CARRILLO, P. M., ANUMBA, C. J., AND AL-GHASSANI, A. $M$. 2001. "Perceptions and barriers in implementing knowledge management strategies in large construction organisations." Proc., RICS Foundation Construction and Building Research Conf. (COBRA) 2001, Glasgow Caledonian Univ., Glasgow, U.K., 451-460.

RODRIGUES, I. Cultura e desempenho de equipes de projetos globais: um estudo em empresas multinacionais brasileiras. Universidade de São Paulo, 2010 (Tese de Doutorado).

ROPELATO, M., FRONZA, F., AMAL, M., E SILVEIRA, M. (2009). Como é tratado o conceito de Born Global na literatura nacional da área de administração?, XII Semead - Empreendedorismo e inovação: 31. São Paulo.

ROSENFELD, Y. Root-Cause Analysis of Construction-Cost Overruns. J. Constr. Eng. Manage, 2014, 140(1): 04013039

ROZENFELD, H.; FORCELLINI, F.A.; AMARAL, D.C.; TOLEDO, J.C.; SILVA, S.L.; ALLIPRANDINI, D.H.; SCALICE, R.K. Gestão de Desenvolvimento de Produtos: uma referência para a melhoria do processo. São Paulo: Saraiva, 2006.

SANTOS, A. POWELL, J. FORMOSO, C. T. Transferência de "Know-How" no Ambiente da Construção Civil. In: Encontro Nacional de Tecnologia do Ambiente Construído - Qualidade no Processo Construtivo. 27 a 30 de abril, 1998, Florianópolis, UFSC, VOL II. 801p. p.9-17. 
SANTOS, M. P. D. Colaboração (delação) Premiada. 2 ed. rev., ampl. e atual. - Salvador: JusPODIVM, 2017.

SANTOS, R. P.; SANTOS, R. M.; SHIBAO, S. Y. Projetos internacionais e os riscos associados à sua gestão. Revista Livre de Sustentabilidade e Empreendedorismo, v. 2, n. 4, p. 63-83, out-dez, 2017 ISSN: 2448-2889

SCHARF, E. R. Gestão do conhecimento aplicada ao Marketing. Florianópolis: Visual Books, 2007.

SHEN, W. et al. Causes of contractors' claims in international engineeringprocurement-construction projects. Journal of Civil Engineering and Management 23(6), pp. 727-739, 2017.

SHENHAR, A.; DVIR, D. "Reinventing project management: The diamond approach to successful growth and innovation". Boston: Harvard Business School Press, 2007.

SILVA, V. F. Análise de risco na construção - guia de procedimentos para gestão. Mestrado Integrado em Engenharia Civil - 2009/2010 - Departamento de Engenharia Civil, Faculdade de Engenharia da Universidade do Porto, Porto, Portugal, 2009.

SILVEIRA, Antônio Augusto. Gestão do conhecimento como ênfase na aprendizagem organizacional: um estudo de multicaso no contexto bancário. Dissertação (Mestrado em Eng. Produção) Programa de PósGraduação em Engenharia de Produção, Universidade Federal de Itajubá, Itajubá, MG, Agosto de 2004.

SINICON, LCA CONSULTORES. Construção civil se retrai em 2017 e segura recuperação da economia. Disponível em g1.globo.com: Acesso em: 26 mai. 2018

SOUSA, F. J. Compatibilização de Projetos em Edifícios de Múltiplos Andares - Estudo de Caso. 2010.103 p. Dissertação (Mestrado em Engenharia Civil),Pró-Reitoria de Ensino, Pesquisa e Extensão - Universidade Católica de Pernambuco. Recife, 2010.

SOUSA, T. D.; AU-YONG OLIVEIRA, M. A internacionalização de empresas portuguesas: uma análise envolvendo casos de multinacionais e PMES. Proceedings of the International Management Conference, 2015.

SRIVANNABOON, S. L., "Project Management With Business Strategy". Project Management Journal, Pennsylvania, p. 88-96. 2006.

SURESH et al. Impacto of knowledge management on construction projects. Proceedings of the Institution of Civil Engeneers Management. Procurement and Law. Volume 170 lssue 1, February 2017, pp. 27-43. 
TEIXEIRA, L. P.; DE CARVALHO, F. M. A. A Construção Civil como instrumento do desenvolvimento da economia brasileira. Revista Paranaense de Desenvolvimento-RPD, n. 109, p. 9-26, 2011.

VALENTIM, M. L. G. P. Gestão da informação e gestão do conhecimento em ambientes organizacionais: conceitos e compreensões. Tendências da Pesquisa Brasileira em Ciência da Informação, v. 1, n. 1, 2008.

VON KROGH, G., NONAKA, I., RECHSTEINER, L. Leadership in organizational knowledge creation: $A$ review and framework. Journal of Management Studies49(1), pp. 240-277, 2012.

WATANUKI et al. Gestão de projetos internacionais: um estudo bibliométrico. Gestão da Produção, São Carlos, v. 21, n. 3, p. 660-675, 2014.

$\mathrm{XIA}$, D.; CHEN, B. A comprehensive decision-making model for risk management of supply chain. Expert Systems with Applications, v. 38, n. 5, p. 4957-4966, maio 2011.

YILDIZ, A. E.; DIKMEN, I.; BIRGONUL, M. T.; ERCOSKUN, K.; ALTEN, S. A knowledge-based risk mapping tool for cost estimation of international construction projects. Automation in Construction, v. 43, p. 144-155, 2014.

YIN R. Estudo de caso: planejamento e métodos. 2a ed. Porto Alegre: Bookman; 2001.

YIN, R. K. (2015). Estudo de caso: planejamento e métodos (5 ed.). (C. M. Herrera, Trad.) Porto Alegre: Bookman.

ZHAO, Z. Y.; SHEN, L. Y. (2008). "Are Chinese contractors competitive in international markets?" Constr. Manage. Econ., 26(3), 225-236. 


\section{APÊNDICE A - QUESTIONÁRIO DE PESQUISA}

\section{APRESENTAÇÃO}

Prezado (a),

Este questionário é parte da etapa de avaliação de uma pesquisa. Gostaria de salientar que a sua participação é muito importante, pois as informações fornecidas servirão para fundamentar uma dissertação de Mestrado da Universidade de São Paulo, cujo tema é "Gestão de projetos de empresas internacionais atuando no Brasil".

Desde já gostaria de garantir que as informações serão guardadas em sigilo, sendo que o nome do respondente e da empresa, objeto de estudo, não serão divulgados. A sinceridade quanto à descrição das respostas é muito importante, pois irá demonstrar a sua real percepção dos aspectos avaliados.

Agradeço a sua contribuição e coloco-me à disposição para eventuais esclarecimentos por meio do endereço de e-mail tielyzm@usp.br.

Atenciosamente,

\section{Tiely ZurloMognhol}

Aluna de mestrado no Programa de Pós-Graduação em Engenharia Civil Departamento de Engenharia de Construção Civil - POLI-USP 


\section{DADOS GERAIS}

\section{BLOCO 01 - CARACTERIZAÇÃO DA EMPRESA}

01) Razão Social (Opcional):

03) Faturamento/ano:

\begin{tabular}{l}
1 - de 0 a 9 \\
\hline 2 - de 10 a 49
\end{tabular}

02) Número de funcionários:

3 - de 50 a 249

4 - de 100 a 249

5 - de 250 ou mais

1 - até 1,0 milhão

2 - de 1,0 a 10,0 milhões

3 - de 10,0 até 50,0 milhões

4 - de 50,0 até 200,0 milhões

5 - acima de 200,0 milhões

\section{BLOCO 02 - DADOS DO RESPONDENTE}

04) Nome (opicional):

05) País de origem:

07) Cargo que ocupa: Gerente de obras/produção

08) Função

empreendimento:

09) Área de atuação:

1 - Gerente/Líder

2 - 1 a 5 anos

$3-5,1$ a 10 anos

$4->10$ anos

2 - Ténico de equipe

3 - Outro (especificar)

Infraestrutura

10) Número

subordinados:

11) E-mail (opcional): 


\begin{tabular}{|c|c|c|}
\hline \multicolumn{3}{|c|}{ BLOCO 03 - DADOS DO EMPREENDIMENTO } \\
\hline \multicolumn{3}{|l|}{ 12) Nome (opcional): } \\
\hline \multirow{2}{*}{ 13) Cliente: } & 1 - Público & \\
\hline & 2 - Particular & \\
\hline \multirow{3}{*}{$\begin{array}{l}\text { 14) Tipo de equipe quanto à } \\
\text { distância geográfica: }\end{array}$} & 1 - Co-localizada & \\
\hline & 2 - Distribuída (mesmo país) & \\
\hline & 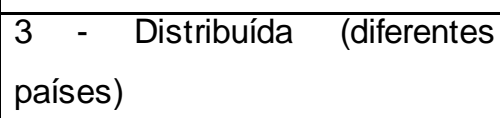 & \\
\hline \multirow{4}{*}{ 15) Tamanho da equipe: } & 1 - até 20 pessoas & \\
\hline & 2 - entre 21 e 100 pessoas & \\
\hline & 3 - entre 101 e 200 pessoas & \\
\hline & 4 - mais de 200 pessoas & \\
\hline \multirow{4}{*}{$\begin{array}{l}\text { 16) Países de origem dos } \\
\text { membros da equipe: }\end{array}$} & \multicolumn{2}{|l|}{ País 1: } \\
\hline & \multicolumn{2}{|l|}{ País 2: } \\
\hline & \multicolumn{2}{|l|}{ País 3: } \\
\hline & \multicolumn{2}{|l|}{ País 4: } \\
\hline
\end{tabular}

\section{DADOS ESPECÍFICOS}

\section{REFERENTE À GESTÃO DE RISCOS DO EMPREENDIMENTO}

1. A empresa conhece as práticas de gestão de projetos (PMBoK, ISO)?

2. A empresa aplica as práticas de gestão de projetos (PMBoK, ISO) em seus empreendimentos?

3. A equipe envolvida em cada empreendimento é exclusiva ou compartilhada?

4. Quais os critérios utilizados para selecionar os profissionais que participam (ou participaram) da equipe do empreendimento?

5. Quem é (era) o responsável pela gestão de riscos do empreendimento?

6. São elaboradas planilhas de riscos (identificação, classificação, respostas) para os empreendimentos da empresa? 
7. A empresa possui dados de riscos que se manifestaram em empreendimentos anteriores?

8. Como os riscos identificados são (eram) controlados?

9. Cite exemplos de situações que ocorrem e como foram tratados?

\section{REFERENTE À GESTÃO DO PROCESSO DE PROJETO (DESIGN)}

10. Existe um procedimento padrão para a Gestão do Processo de Projeto? Em qualquer hipótese, explique.

11. Quais os critérios utilizados para selecionar os profissionais que participam (ou participaram) da equipe do projeto?

12. Quais os mecanismos utilizados para gerenciar e desenvolver a equipe do projeto?

13. Quem é o responsável pelo processo de coordenação de projetos do empreendimento?

14. Considera (va) adequado o nível de detalhes dos projetos (design)?

15. Existe um procedimento para checar a compatibilidade entre as diferentes disciplinas do projeto? Qual equipe é responsável por fazer essa análise?

16. Existe padronização nos arquivos digitais para a troca de informações dos projetos (design) entre os agentes envolvidos no empreendimento? Quais?

17. Quais procedimentos são adotados no caso em que as informações entre os projetos não correspondem?

18. Cite exemplos em que a gestão do processo de projeto obteve bons resultados. Explique. 


\section{REFERENTE À GESTÃO DA INFORMAÇÃO E DO CONHECIMENTO DO EMPREENDIMENTO}

19. Quais fontes de informação e conhecimento são percebidas em seu trabalho?

20. Quais ferramentas são adotadas pela empresa no processo de gestão da informação e do conhecimento?

21. As equipes do empreendimento recebem treinamento para uso das ferramentas identificadas no item anterior?

22. Existem mecanismos gerenciais para validar a base de informação e conhecimento, manter este acervo, ampliá-lo, cuidar de seu registro e verificar sua utilização?

23. Como as atividades dos colaboradores, referentes às informações e ao conhecimento são valorizadas? Qual a forma de retorno prevista para estes trabalhos?

24. Você acredita que as informações e o conhecimento são absorvidos / registrados / aplicados conforme o previsto?

25. O uso das informações e conhecimentos armazenados é utilizado para fins estratégicos (outros projetos, tomada de decisão, etc.)?

\section{REFERENTE À GESTÃO DA COMUNICAÇÃO DOS ENVOLVIDOS NO EMPREENDIMENTO}

26. A empresa possui um processo para gestão da comunicação?

27. São feitas reuniões das equipes para tratar dos assuntos mais relevantes do projeto? Quem participa?

28. Como são coordenadas as necessidades do cliente, em especial, aquelas que afetam o escopo contratado? 
29. Existe algum conflito com as partes interessadas do empreendimento? Cite exemplos.

\section{REFERENTE AO SUCESSO DOS EMPREENDIMENTOS}

30. Quais são as principais barreiras para encontrar o sucesso nesse tipo de empreendimento? Por favor, você poderia dar exemplos concretos com base na sua experiência.

31. E os principais facilitadores? Por favor, você poderia dar exemplos concretos com base na sua experiência.

32. Como você acha que a diversidade cultural influencia o desempenho da equipe do empreendimento? Por favor, você poderia dar exemplos concretos com base na sua experiência.

33. Que tipos de conflitos causados por diferenças culturais ocorrem na gestão dos empreendimentos?

34. Por que ocorrem? Cite exemplos.

35. Como os conflitos são gerenciados pelo líder do empreendimento?

36. Qual o nível de suporte organizacional que o gerente do empreendimento recebe para lidar com os conflitos?

37. Como foi gerenciada a diversidade cultural no seu empreendimento? Por favor, você poderia dar exemplos concretos com base na sua experiência.

38. Em sua opinião, o que contribui para que uma equipe do empreendimento seja bem sucedida? Por favor, você poderia dar exemplos específicos com base na sua experiência. 